\title{
The Sacred in the Profane: Understanding Andy Warhol's Relationship with the Visual Image
}

\author{
Linda Rosefsky \\ West Virginia University
}

Follow this and additional works at: https://researchrepository.wvu.edu/etd

\section{Recommended Citation}

Rosefsky, Linda, "The Sacred in the Profane: Understanding Andy Warhol's Relationship with the Visual Image" (2011). Graduate Theses, Dissertations, and Problem Reports. 749.

https://researchrepository.wvu.edu/etd/749

This Thesis is protected by copyright and/or related rights. It has been brought to you by the The Research Repository @ WVU with permission from the rights-holder(s). You are free to use this Thesis in any way that is permitted by the copyright and related rights legislation that applies to your use. For other uses you must obtain permission from the rights-holder(s) directly, unless additional rights are indicated by a Creative Commons license in the record and/ or on the work itself. This Thesis has been accepted for inclusion in WVU Graduate Theses, Dissertations, and Problem Reports collection by an authorized administrator of The Research Repository @ WVU. For more information, please contact researchrepository@mail.wvu.edu. 
The Sacred in the Profane:

Understanding Andy Warhol's Relationship with the Visual Image

\author{
Linda Rosefsky
}

Thesis submitted to the

College of Creative Arts

at West Virginia University

in partial fulfillment of the requirements

for the degree of

\author{
Master of Arts \\ in \\ Art History
}

Examining Committee:

Kristina Olson, M.A., Chair,

Division of Art and Design

Janet Snyder, Ph.D.,

Division of Art and Design

Jane B. Donovan, D.Min.,

Department of Religious Studies

Cynthia Persinger, Ph.D., California University of Pennsylvania

Department of Art and Design

\title{
Morgantown, West Virginia
}

2011

Keywords: Andy Warhol, Late Work, Raphael I-6.99, Oxidation, Carpatho-Rusyn, Byzantine Catholicism 


\section{ABSTRACT \\ The Sacred in the Profane: \\ Understanding Andy Warhol's Relationship with the Visual Image}

\section{Linda Rosefsky}

For Andy Warhol (1928-1987), images meant for commercial advertisement, tabloid publication, and entertainment were not merely meaningless reflections of a commodity and media-obsessed world - they were sacred. In 1986, the Pop artist based the last major series of his career on a reproduction of a Renaissance masterpiece, Leonardo da Vinci's Last Supper (1495-97/98, figure 1). Given the slick packaging of Warhol's oeuvre and his cool public persona, it would be easy to dismiss these late paintings as a cynical comment on the proliferation of images in American society. Viewing The Last Supper series from the perspectives of biography, psychology, and cultural identity, however, has led to a startling conclusion that refutes decades of postmodern analysis categorizing Warhol as a shallow artist limiting himself to the simulacral surface. The son of Carpatho-Rusyn immigrants and a devout Byzantine Catholic, Warhol's relationship with the visual image was formed by a rich cultural heritage in which icons, or holy pictures, are experienced as sacred doorways that make the unseen world real. Although he convincingly played the role of a scheming hipster defiantly blurring the line between commercial and fine art, Warhol's style and technique expose his lifelong connection to the religious imagery with which he grew up. 


\section{ACKNOWLEDGMENTS}

This Master's Thesis would not have been possible without the wisdom, guidance, and support of my mentors: Professor Kristina Olson, Dr. Janet Snyder, and Dr. Rhonda Reymond from the College of Creative Arts at West Virginia University, Dr. Jane B. Donovan from the Eberly College of Arts and Sciences at West Virginia University, and Dr. Cynthia Persinger from the Department of Art and Design at the California University of Pennsylvania. Their unwavering enthusiasm and encouragement motivated me through years of research and inspired me to accomplish what I never would have thought possible.

Writing this Thesis involved an enormous commitment of time and energy. I am immensely grateful to my husband Adam and my daughter Sarah for the many sacrifices they have made to help me achieve this milestone in my life. 


\section{TABLE OF CONTENTS}

$\begin{array}{ll}\text { ABSTRACT } & \text { ii }\end{array}$

ACKNOWLEDGMENTS $\quad$ iii

LIST OF FIGURES

INTRODUCTION 1

PART I: Andy Warhol's Cultural Background

I. The Development of the Eastern Churches 2

II. “I Come from Nowhere:” Warhol’s Carpatho-Rusyn Heritage 5

$\begin{array}{ll}\text { III. Icons and the Veneration of Images } & 14\end{array}$

IV. The Liturgy of St. John Chrysostom 19

$\begin{array}{lll}\text { V. Iconoclasm } & 22\end{array}$

VI. The Byzantine Catholic Church in Russia 25

$\begin{array}{ll}\text { VII. Carpatho-Rusyns in America } & 30\end{array}$

VIII. The Warholas Come to Pittsburgh 34

PART II: The Art of Andy Warhol

$\begin{array}{lll}\text { IX. American Pop } & 37\end{array}$

$\begin{array}{ll}\text { X. Like a Machine } & 40\end{array}$

XI. Skulls and other Precious Relics 47

XII. Finding the Sacred in the Profane: Oxidation 51

XIII. Shadows: Imitate, Replicate, Repeat 60

XIV. For What it's Worth: Warhol's Madonna 68

XV. The Last Supper $\quad 77$

$\begin{array}{ll}\text { CONCLUSION } & 86\end{array}$

$\begin{array}{ll}\text { FIGURES } & 88\end{array}$ 


\section{LIST OF FIGURES}

Figure

Page

1. Leonardo da Vinci, Last Supper, 1495-1497/98 88

2. Icon of The Holy Face (Acheiropoietos), $12^{\text {th }}$ Century 88

3. Icon of Christ Pantocrater, $6^{\text {th }}$ Century 89

4. Icon of Virgin of Vladimir, $12^{\text {th }}$ Century $\quad 89$

5. Icon of The Communion of the Apostles 90

6. Photograph of Iconostasis 90

7. Andy Warhol, Dick Tracy, 1960

8. Andy Warhol, TV \$199, 1960

9. Andy Warhol, Cow Wallpaper (installation), 1966

10. Andy Warhol, Self-Portrait, 1986

11. Andy Warhol, Self-Portrait, 1986

12. Andy Warhol, Gold Marilyn Monroe, 1962

13. Icon of Christ the Redeemer 94

14. Andy Warhol, Silver Clouds (installation), 1966

15. Andy Warhol, Skull, 1976

16. Andy Warhol, Campbell's Soup Cans, (Chicken with Rice, Bean with

Bacon), $1962 \quad 95$

17. David Bailly, Vanitas Still-life with a Portrait of a Young Painter, 165196

18. Andy Warhol, Self-Portrait with Skull, $1978 \quad 96$

19. Icon of The Crucifixion 97

20. Icon of The Crucifixion (detail) 97

21. Andy Warhol, Skull, 1976 
22. Andy Warhol, Oxidation Painting, $1978 \quad 98$

23. Andy Warhol, Oxidation Painting (in 12 parts), 1978

24. Andy Warhol, Elvis 11 Times, 1963

25. Andy Warhol, Golden Boy, $1957 \quad 100$

$\begin{array}{ll}\text { 26. Icon of St. Andrew } & 100\end{array}$

27. Andy Warhol, Sex-Parts, $1978 \quad 101$

28. Andres Serrano, Piss Christ, $1987 \quad 101$

29. Andy Warhol, Shadows (installation), $1978 \quad 102$

30. Andy Warhol, The Last Supper (Be Somebody with a Body) (detail), 1985/86 102

31. Barnett Newman, The Stations of the Cross: Lema Sabachthani, $1966 \quad 103$

32. Barnett Newman, The Stations of the Cross: Lema Sabachthani, Fourteenth $\begin{array}{ll}\text { Station, } 1966 & 103\end{array}$

33. Andy Warhol, Double Silver Disaster, $1963 \quad 104$

34. Raphael, Sistine Madonna, 1513/14 104

35. Andy Warhol, Raphael I-6.99, 1985

36. Encyclopedia Illustration of Raphael's Sistine Madonna, $19^{\text {th }}$ Century 105

37. Andrea Ritzos, Icon of the Dormition of the Virgin, $15^{\text {th }}$ Century 106

38. Icon of the Nativity of Christ 106

39. Photograph of Madonna, $1984 \quad 107$

40. Andy Warhol, The Last Supper (Pink) (installation), 1986

41. Andy Warhol, The Camouflage Last Supper (detail), $1986 \quad 108$

42. Andy Warhol, The Last Supper (Dove), $1986 \quad 108$

43. Andy Warhol, Sixty Last Suppers (detail), $1986 \quad 109$

44. Andy Warhol, 200 Campbell's Soup Cans, 1962

45. Andy Warhol, Sixty Last Suppers (installation), $1986 \quad 110$ 


\section{INTRODUCTION}

Most of the discourse surrounding Warhol's work centers on the ground-breaking imagery he produced during the early phase of his career, in the 1960s. The common perception is that after that prolific decade, Warhol's work failed to resonate in the same compelling manner; recent research shows how short-sighted this view is. ${ }^{1}$ In the process of analyzing several paintings Warhol created during his most prolific years - his last decade - I have discovered that Warhol's imagery does more than reflect the highly stylized language of mass media advertising. Warhol's work speaks of his Carpatho-Rusyn heritage and the Byzantine Catholic religion he quietly practiced throughout his life. A consideration of Skull (1976), Shadows (1976), Oxidation (1978), Raphael I-6.99 (1985), and The Last Supper (1986) will show that Warhol's relationship with his Pop images is like the believer's relationship with the Byzantine icon - it is transcendental. This transcendental quality is not limited to his late works; it radiates throughout Warhol's entire body of work. ${ }^{2}$ Whether the subject is a humble can of soup, a glamorous movie star, or a proverbial masterpiece, Warhol's most significant contribution to twentieth-century art was his ability to transform the everyday and banal into an icon, to find the sacred in the profane.

The historical perception of Warhol's Pop imagery, reinforced by the artist's claim "There's nothing behind it," will make this radical re-interpretation of his work a difficult

\footnotetext{
${ }^{1}$ In 1998, art historian Jane Daggett Dillenberger produced a ground-breaking study in which she examines several of Warhol's late works that are religious in content. See Jane Daggett Dillenberger, The Religious Art of Andy Warhol (New York: The Continuum Publishing Company, 1998).

${ }^{2}$ Although a visual presence resides in other forms of Byzantine art that Warhol would have been familiar with, such as the Epitathios used in the Divine Liturgy during certain times of the year, the focus of this paper is on panel paintings.
} 
prospect. ${ }^{3}$ Warhol defiantly rejected the transcendental mystique of Abstract Expressionism and embraced mechanically-produced images of Pop culture - signs of reality that were instantly recognizable, easily reproducible, and ready for consumption. Preliminary research shows that the processed food, alluring celebrities, and corporate logos in Warhol's paintings represent something far more personal than empty signs and shallow signifiers. With what may be regarded as a "closeted presentation" to a largely Protestant American audience, Warhol created evocative imagery imbued with the real presence found in Byzantine icons. The belief that there is a real presence in an icon is a concept unique to Byzantine Catholicism; it is a defining distinction between Eastern and Western Catholicism. To fully understand the psychological impact of Byzantine Catholicism on Warhol's psyche, and consequently his art, it is essential to begin this discussion with an exploration of this overlooked and often misunderstood faith. There is an assumption in much of the Western world that Roman Catholicism and Protestantism are the primary forms of Christianity, thus Eastern Orthodox Christianity is frequently ignored. The following is an overview of the origins of Christianity in the East.

\section{Chapter I: The Development of Eastern Churches}

Separate from their Western counterparts, Eastern Churches grew as a result of the division of the Roman Empire into Eastern and Western halves. In the latter part of the thirdcentury, when the pagan Roman emperor Diocletian found that his empire had grown too large for one individual to govern, he divided it between himself and a co-emperor, Decius, each with separate royal bureaucracies. The balance of power shifted to the eastern part of

\footnotetext{
${ }^{3}$ In the numerous interviews Warhol gave throughout his career, he revealed little about his personal identity and what motivated his art. In a 1967 interview with art critic Gretchen Berg, the artist said "If you want to know all about Andy Warhol, just look at the surface of my paintings and films and me, and there I am. There's nothing behind it." See David Bourdon, Warhol (New York: Aradale Press/Harry N. Abrams, Inc., 1989), 10 .
} 
the empire when Diocletian made it his home; his successor, Constantine the Great (274-337 CE) attempted to reunite the empire. ${ }^{4}$

After enduring years of cruel persecution from the Roman Empire, the members of the Christian Church were liberated when Constantine began a military campaign that would make him master of his empire. According to Christian authors who knew the emperor, on the eve of the decisive battle on the Milvian Bridge a revelation came to him in a dream, and Constantine was commanded to place the "heavenly sign of God" on the shields of his soldiers. The following day, he had the Greek letters chi and rho, the first two letters of Christ's name, superimposed on their shields. Eventually Christians regarded this event as the great moment of Constantine's conversion, the consequences of which left a lasting impression on Christianity. ${ }^{5}$ For Constantine, Christianity represented a divine victory over the forces of evil and, accordingly, the Chi-Rho and cross were adopted as imperial symbols. The ruler believed that God had chosen him to bring the Roman Empire to Christianity, and that God would bless his reign and give the empire peace and prosperity in return. ${ }^{6}$

In 313, the year following his triumph in the Battle of the Milvian Bridge, Constantine issued the Edict of Milan, which put an end to religious persecution and granted all people in the Roman Empire the freedom to worship whatever God they wished. ${ }^{7}$ In 324 he refounded the ancient city of Byzantium, making the old Greek city-state his new Eastern capital. ${ }^{8}$ After struggling for several years to be the master of the entire Empire, Constantine

\footnotetext{
${ }^{4}$ Catherine A. Cory and Michael J. Hollerich, eds., The Christian Theological Tradition (New Jersey: Pearson Prentice Hall, 2009), 195.

5 Justo L. Gonzales, The Story of Christianity, Volume 1: The Early Church to the Dawn of the Reformation (New York: HarperCollins Publishers, 1984), 106-107.

${ }^{6}$ Cory and Hollerich, The Christian Theological Tradition, 163.

${ }^{7}$ Gonzales, The Story of Christianity, Volume 1: The Early Church to the Dawn of the Reformation, 106107.

${ }^{8}$ Michael Angold, Byzantium: The Bridge from Antiquity to the Middle Ages (New York: St. Martin's Press, 2001), 1-14.
} 
strove to preserve the unity of the Roman world around his new capital. Unlike his pagan predecessors, Diocletian and Decius, Constantine believed that he could build this unity on the foundations of Christianity. Undaunted by the objections of the Roman Senate, he vowed to build a "New Rome" in Byzantium, an impenetrable and explicitly Christian city to be called Constantinople, the "city of Constantine.",

Throughout the following centuries, the Christian Roman Empire was threatened by various forces on all sides. Muslims diminished Roman territory in the East, conquering the apostolic patriarchates of Jerusalem, Alexandria, and Antioch. The pagan Bulgarians were a constant threat from the North. In the West, the consolidation of Frankish power symbolized by Charlemagne's coronation as Holy Roman Emperor destroyed the notion of unity in the political empire and foreshadowed the separation of religious territories. ${ }^{10}$ As one of the preeminent cities of the Middle Ages, Constantinople played a vital role in the emergence of the medieval order in which Byzantium, western Christendom, and Islam became three distinct civilizations. ${ }^{11}$ Constantinople became the center that preserved the political and cultural legacy of the old empire. Since its capital was in ancient Byzantium, this Eastern Roman Empire came to be known as the Byzantine Empire. ${ }^{12}$ At its peak, the Empire stretched from the Euphrates to the Straits of Gibraltar. ${ }^{13}$

The primary form of Christianity that developed in the Byzantine Empire is known as Eastern Orthodoxy. Orthodoxy is a communion of churches whose bishops gather at a

\footnotetext{
${ }^{9}$ Gonzales, The Story of Christianity, Volume 1: The Early Church to the Dawn of the Reformation, 118.

${ }^{10}$ Catherine P. Roth, in Theodore the Studite, On the Holy Icons (Crestwood, New York: St. Vladimir's Seminary Press, 2001), 7.

${ }^{11}$ Michael Angold, Byzantium: The Bridge from Antiquity to the Middle Ages, 1-2.

${ }^{12}$ Gonzales, The Story of Christianity, Volume 1: The Early Church to the Dawn of the Reformation, 120.

${ }^{13}$ Linette Martin, Sacred Doorways: A Beginner's Guide to Icons (Brewster, MA: Paraclete Press, 2002), 6.
} 
council of regional patriarchates of Constantinople, Alexandria, Antioch, and Jerusalem. All Orthodox Christians recognize the patriarch of Constantinople as "first among equals." Beginning in the ninth century, Byzantine missionaries established national churches among various ethnic groups outside the empire's borders. Their efforts produced Orthodox churches of Russia, Romania, Greece, Serbia, Bulgaria, Georgia, Cyprus, Poland, Albania, and Slovakia, where Warhol's ancestors originated. ${ }^{14}$ The Byzantine Rite that Warhol's family used in celebrations of the Mass developed in this part of the world that is seldom recognized in the West. The following is a synopsis of the Carpatho-Rusyn culture - its rich history, beliefs, and customs.

\section{Chapter II: “I Come from Nowhere:” Warhol’s Carpatho-Rusyn Heritage}

\section{I'd prefer to remain a mystery, I never like to give my background and,} anyway, I make it all up different every time I'm asked.

$$
\text { Andy Warhol }{ }^{15}
$$

Although Warhol alleged that he "came from nowhere," he was born Andrew Warhola, the youngest of three children of Slovakian immigrants who had come to America to escape the poverty of their homeland, a small village called Mikova in the Carpathian Mountains of east-central Europe. ${ }^{16}$ Rusyn, Rusnak, Uhro-Rusin, Carpatho-Russian, Ruthenian, CarpathoUkrainian, Lemko, Slavish, Byzantine: the Slavs from the Carpathian Mountain region have been referred to by all of these terms at one time or another. Their homeland has been known by many names as well: Subcarpathian Rus', Carpatho-Ruthenia, Carpatho-Russia, Carpatho-Ukraine. Not surprisingly, historians have observed that a large percentage of

\footnotetext{
${ }^{14}$ The term Orthodox is formed from two Greek words meaning "right praise" or "right opinion." See Cory and Hollerich, The Christian Theological Tradition, 196.

${ }^{15}$ As quoted in Andy Warhol “Giant” Size (London: Phaidon Press Limited, 2006), 70.

${ }^{16}$ Andy Warhola became Andy Warhol early in his career, when he worked as a commercial artist. The ' $a$ ' was inadvertently omitted from Warhol's signature in an illustration he had created for an article in the September, 1949 issue of Glamour magazine; the artist retained the truncated name thereafter. See Bourdon, Warhol, 26.
} 
those of Carpatho-Rusyn descent struggle to define their European heritage. ${ }^{17}$ CarpathoRusyns have never had their own state, and since the sixth and seventh centuries they have existed as a national minority, first in the kingdoms of Hungary and Poland, and then in the Austro-Hungarian Empire. Since the end of World War I, as European borders have changed, Carpatho-Rusyns have found themselves living in several different countries at one time or another: first in Czechoslovakia and Poland, then in Hungary, Slovakia, and Nazi Germany during World War II. After the war, their homeland was part of the Soviet Ukraine, Czechoslovakia, and Poland. Since the Revolution of 1989 in East-Central Europe and the fall of the Soviet Union two years later, the Carpatho-Rusyns have lived, for the most part, in three countries: Ukraine, Slovakia, and Poland. ${ }^{18}$

Scholarship on the origins of the Slavs has been limited. With a few exceptions, textbooks of European history only provide brief generalizations on the subject. Authors tend to limit their search to the beginning of the nineteenth-century when Europe was divided into two halves, Western and Eastern. They tend to neglect the Eastern half due to the nineteenth-century colonist view that the East is, as historian P.M. Barford wrote, "an appendage, a cultural backwater merely acting as a passive recipient of the benefits of Western civilization." ${ }^{19}$ Despite this scholarly lack of interest, numerous theories exist concerning the origins of the Carpatho-Rusyns. For many years, historians thought that all the Slavs originated in the Carpathian region. Most now agree that the original Slavic homeland was just north of the Carpathians, in what are today eastern Poland, southwestern Belorussia, and northwestern Ukraine. Historian Paul Magocsi hypothesizes that the Slavs,

\footnotetext{
${ }^{17}$ Paul Robert Magocsi, Our People: Carpatho-Rusyns and Their Descendants in North America (Ontario: Multicultural History Society of Ontario, 1984), 1-5.

${ }^{18}$ Paul Robert Magocsi, “Carpatho-Rusyn Americans” (accessed November 15, 2009), http://www.everyculture.com/multi/Bu-Dr/Carpatho-Rusyn-Americans.html.

${ }^{19}$ P.M. Barford, The Early Slavs (Ithaca, New York: Cornell University Press, 2001), 1-2.
} 
who called themselves Rusyns, first settled in the Carpathian Mountains during the great migration that took place in the sixth and seventh centuries; they came from regions immediately to the north and east, such as Galicia, Volhynia, and Podolia (western Ukraine). Larger waves of immigration occurred after the thirteenth-century, mostly from Galicia, often at the request of a Hungarian government anxious to protect its northern frontier by settling it with people. ${ }^{20}$ During the Slavic expansion of the sixth-century, this frontier separated the Roman Empire from the area beyond. For the Romans, it was a political boundary that separated the "civilized" from the "barbarians," or the Slavs. The term 'Slavs' was later used in the West to refer to other groups lying beyond their borders. ${ }^{21}$

Just as the question of a European homeland for Carpatho-Rusyns has remained unanswered, the way in which they converted to Christianity has also been problematic. Although there is a difference of opinion among historians, the Byzantine Catholic Church favors the "Western Methodian" interpretation. ${ }^{22}$ Cyril, who was originally known as Constantine (b. 827), and Methodius (b. 825) were brothers from a noble family in northeastern Greece. After they both entered the priesthood, Cyril, known as "the philosopher," embarked on a mission to the Arabs and later became a professor of philosophy at the imperial school in Constantinople and a librarian at the largest church in Christendom, the Hagia Sophia, or Church of Holy Wisdom. Methodius became governor of a district that had been settled by Slavs. After the brothers retired to monastic life, they were sent to work with the Khazars northeast of the Black Sea in the Dnieper-Volga region of

\footnotetext{
${ }^{20}$ Magocsi, Our People: Carpatho-Rusyns and Their Descendants in North America, 6-7.

${ }^{21}$ Barford, The Early Slavs, 6, 23.

${ }^{22}$ Magocsi, Carpatho-Rusyns and Their Descendants in North America, 7.
} 
what later became Russia. There they learned the Khazar language, made many converts, and discovered what were believed to be relics of Clement, an early Bishop of Rome. ${ }^{23}$

In about 863, Cyril and Methodius were sent to Greater Moravia (now the eastern

Czech Republic) and western Slovakia, at the request of Prince Rostislav to teach his people in their own language rather than the Latin used by western missionaries. ${ }^{24}$ The request was well received by Constantinople; it was regarded as an opportunity to extend Byzantine influence. $^{25}$ An excerpt from the letter read:

Many Christians have arrived in our midst, some Italian, some Greek, and some German, and they have spoken to us in their different ways. But we Slavs are simple people, and have no one to teach us the truth...Therefore we pray you to send us someone capable of teaching us the whole truth. ${ }^{26}$

The brothers were welcomed in Moravia. They translated the Liturgy and much of the Scriptures into Slavonic, a language for which there was no written form, and invented the Glagolitic, a Slavonic alphabet which gave rise to the Cyrillic alphabet (named for Cyril). Cyrillic is still used to write Russian and several related languages today. Since Cyril and Methodius were the first to produce written material in the Slavic languages, they are widely regarded as the founders of Slavic literature. ${ }^{27}$ The brothers translated a wide variety of evangelical and liturgical texts and writings of the church fathers, as well as their own works. ${ }^{28}$ The translation of the Gospels and Liturgy into Slavonic languages meant that for

\footnotetext{
${ }^{23}$ James Kiefer, "Cyril and Methodius" (accessed May 11, 2009), http://satucket.com/lectionary/Cyril\&Methodius.htm.

${ }^{24}$ Kiefer, "Cyril and Methodius" (accessed May 11, 2009), http://satucket.com/lectionary/Cyril\&Methodius.htm.

${ }^{25}$ Gonzales, The Story of Christianity, Volume 1: The Early Church to the Dawn of the Reformation, 263.

${ }^{26}$ Excerpt from a letter written by Prince Rostislav to authorities in Constantinople, quoted in G. Zananiri, Histoire de l'eglise Byzantine (Paris: Nouvelles editions latines, 1954), 185.

${ }^{27}$ Kiefer, "Cyril and Methodius" (accessed May 11, 2009), http://satucket.com/lectionary/Cyril\&Methodius.htm.

${ }^{28}$ Paul R. Magocsi and Ivan Pop, eds., Encyclopedia of Rusyn History and Culture (Toronto: University of Toronto Press, 2002), 73.
} 
the first time in Moravia, Bulgaria, and Kievan Rus, the Bible was read in a non-classical language, which allowed Christian scriptures to be heard by all members of the congregation. The introduction of a Slavic liturgy in Moravia was an important event; it shows that the aim of the Byzantine mission was not to convert the educated elite, but to evangelize the common people. $^{29}$

The efforts of Cyril and Methodius were opposed by the conservative western church; the Roman bishops in Moravia were more interested in the political role of a more elitist Christianity. ${ }^{30}$ Roman-rite priests from neighboring Bavaria refused to recognize the legitimacy of Slavonic as a liturgical language. In an effort to resolve this dispute, the brothers traveled to Rome in 867 to receive the support of Pope Adrian II. ${ }^{31}$ For centuries, the brothers have customarily been referred to as the "Apostles to the Slavs," especially in the United States. ${ }^{32}$ By the middle of the twentieth-century, however, this "western Methodian" interpretation of how the Slavs received Christianity began to be challenged by some historians. Although most would agree that Methodius and Cyril's efforts were significant to the development of the Slavs, scholars are no longer convinced that the brothers played an essential role in the conversion of the Moravian pagans to Christianity. In Cyril's biography, Prince Rastislav's letter requesting that the brothers come to Moravia states that his people had already rejected paganism and were observing Christian rules. Some see this declaration as an exaggeration, however, and attribute it to the biographer. ${ }^{33}$

${ }^{29}$ Barford, The Early Slavs, 215-216.

${ }^{30}$ Barford, The Early Slavs, 215-216.

${ }^{31}$ Magocsi and Pop, Encyclopedia of Rusyn History and Culture, 73.

${ }^{32}$ Magocsi, Carpatho-Rusyns and Their Descendants in North America, 6.

${ }^{33}$ Archaeological discoveries made in Moravia in the mid-twentieth century confirm the Prince's assertion; the foundations of several churches were discovered, at least five of them having been erected sometime in the eighth-century, before the mission of the Greek brothers. Some scholars attribute the rectangular presbytery of one of the churches to early Iro-Scottish architecture, and conclude that the first 
Despite differences in interpretation, most Rusyn intellectuals proudly claim the heritage of Cyril and Methodius, and their missionary work is acknowledged and celebrated in the Byzantine Catholic Church. ${ }^{34}$ As a result of their efforts, the brothers from Macedonia succeeded in incorporating Slavonic as a liturgical language alongside Latin, Greek, and Hebrew. ${ }^{35}$ Church Slavonic, which was based on South Slavic dialects, remains the liturgical and literary language used by the Byzantine Eastern Rite today. ${ }^{36}$ Rusyn historical tradition attributes the establishment of the Eparchy of Mukačevo, the oldest among Byzantine Rite Christians in the Hungarian Kingdom, either to Cyril and Methodius themselves or to their disciples. ${ }^{37}$ The Byzantine Catholic Metropolitanate of Pittsburgh views itself as the successor to the Diocese of Mukačevo. ${ }^{38}$ Cyril and Methodius are honored by Eastern and Western Christians alike; the importance of their work in preaching in the language of the people is recognized on both sides. ${ }^{39}$

The Carpatho-Rusyns were strongly influenced by Roman Catholic Europe for centuries after the Byzantine mission. Since neighboring Roman Catholic countries such as Hungary and Poland treated their Orthodox-Rus' inhabitants as second-class citizens, several eastern hierarchs and some priests began to accept the idea of a union with Rome, in hopes of

missionaries in Moravia must have been Iro-Scottish monks from Bavarian monasteries. If this is true, Christianity came to the Slavs during the Iro-Scottish missions of the late eighth-century, and not the Byzantine mission, which is now believed to have been more political than religious in nature. See Francis Dvornik, "The Significance of the Missions of Cyril and Methodius," Slavic Review 23 (June, 1964): 195-200.

${ }^{34}$ Magocsi, Carpatho-Rusyns and Their Descendants in North America, 7.

${ }^{35}$ Magocsi and Pop, Encyclopedia of Rusyn History and Culture, 73.

${ }^{36}$ Andrew Shipman, "Ruthenians," Catholic Encyclopedia. (accessed May 11, 2009), http://www.newadvent.org/cathen/13278a.htm.

${ }^{37}$ An eparchy is a diocese of an Eastern Orthodox Church. See Magocsi and Pop, Encyclopedia of Rusyn History and Culture, 138.

${ }^{38}$ Magocsi, Carpatho-Rusyns and Their Descendants in North America, 7.

${ }^{39}$ Kiefer, "Cyril and Methodius" (accessed May 11, 2009), http://satucket.com/lectionary/Cyril\&Methodius.htm. 
improving their sociocultural status. ${ }^{40}$ Uniatism is considered to have begun with the Union of Brest in 1596, an agreement that brought the Orthodox metropolitan province of Kiev into full communion with the Roman Catholic Church. ${ }^{41}$ Declarations of unity were proclaimed which resulted not in direct absorption into Roman Catholicism, but in the creation of a new institution known as the Uniate and later as the Greek, or Byzantine Catholic Church. ${ }^{42}$ The formation of the Uniate Church was related in part to events connected with the seventeenthcentury Counter Reformation, that is, the reaction of the Roman Catholic Church to the setbacks it had experienced throughout much of Europe during the sixteenth-century Protestant Reformation. ${ }^{43}$

According to the acts of the union, the Byzantine Catholic Church was permitted to retain its Eastern Rite Liturgy in the Slavonic tongue and its traditional customs, yet at the same time the new church recognized the Pope in Rome and not the Ecumenical Patriarch in Constantinople as its ultimate head. ${ }^{44}$ Throughout its history, the concept of a Uniate Church in the form of the Byzantine Catholic Church and its Eastern traditions has been threatened by the Roman Catholic ecclesiastical and secular authorities in Hungary and Poland. Periodically, the Byzantine Rite has been subjected to Latinizing influences, the Church Slavonic liturgical language has been challenged, and there have been periodic attempts to replace the Cyrillic with the Latin alphabet. Despite these problems, the union has played a positive role in the history of the Carpatho-Rusyn people. After Rusyn priests were exposed to the culture of Western Europe, they were able to study in seminaries and universities, and

\footnotetext{
${ }^{40}$ Magocsi, Carpatho-Rusyns and Their Descendants in North America, 8-9.

${ }^{41}$ Richard P. McBrien, ed., The Harpercollins Encyclopedia of Catholicism (San Francisco: HarperCollins Publishers, 1995), 195.

${ }^{42}$ Magocsi, Carpatho-Rusyns and Their Descendants in North America, 8-9.

${ }^{43}$ Magocsi and Pop, Encyclopedia of Rusyn History and Culture, 480.

${ }^{44}$ Magocsi, Carpatho-Rusyns and Their Descendants in North America, 8-9.
} 
developed a new educational system. The integration of western customs provided the basis for the development of a clerical and secular Rusyn intelligentsia. ${ }^{45}$

The Uniate Church drove the development of ecclesiastical art which drew its inspiration from western and Byzantine circles, as well as new architectural styles. Established exclusively in central towns, the earliest churches were impressive basilicas and smaller private chapels, which were meant for single families or clans. ${ }^{46}$ These buildings were in usually one of two forms: either that of the western European early medieval church, some of which are basilican, or the 'rotunda' type, a circular building with eastern apses. From the ninth to the twelfth-century, the rotunda gained popularity in central Europe. Multi-cellular structures with multiple domes on the Byzantine model were constructed among the South Slavs of the Balkans and the East Slavs. The Hagia Sophia in Constantinople, considered the supreme achievement of Byzantine architecture, served as a model for this kind of church. ${ }^{47}$

With its colossal dome, the Hagia Sophia replaced a fourth-century church which was destroyed when rebels set fire to the old church during the Nika Riot of $532 .^{48}$ Because the Church and the empire were seen as one, in 538 the emperor Justinian rebuilt the Hagia Sophia as a symbol of working together in harmony for the common good. ${ }^{49}$ In order to create a house of worship that would embody the authority, majesty and splendor of a mighty empire, Justinian hired architects Anthemius of Tralles, a specialist in geometry and optics, and Isodore of Miletus, a specialist in physics who had studied vaulting. Together they developed a unique and magnificent design that reconciled the desire for an elevated

\footnotetext{
${ }^{45}$ Magocsi and Pop, Encyclopedia of Rusyn History and Culture, 481.

${ }^{46}$ Barford, The Early Slavs, 216.

${ }^{47}$ Cory and Hollerich, The Christian Theological Tradition, 197.

${ }^{48}$ Cyril Mango, Byzantine Architecture (New York: Electa/Rizzoli, 1978), 61.

${ }^{49}$ Cory and Hollerich, The Christian Theological Tradition, 197.
} 
heavenly space and the need to focus attention below, on the altar and the liturgy. ${ }^{50}$

Although the liturgy used in Hagia Sophia in the sixth-century has been lost, it is assumed that the rites resembled those of later periods which are known in detail. The celebration of the Mass took place behind a crimson curtain embroidered in gold. Later churches replaced the curtain with an iconostasis, a screen of icons known as ayies eikones, or holy pictures (figure 6). ${ }^{51}$

The iconostasis separates the sanctuary from the nave (the earthly from the divine), and at the same time indicates the connection between the two worlds of heaven and earth. ${ }^{52}$ The priests and deacons performed their sacred rites behind the screen, out of the congregation's view, leaving them to focus on the iconostasis and the dome. This upward focus reflects the interest of Byzantine philosophers, who viewed meditation as a way to rise from the material world to a spiritual state. ${ }^{53}$ In subsequent centuries, this style of architecture developed to give the typical form of the Eastern Orthodox Church. ${ }^{54}$ These extraordinary places of worship were adorned with precious mosaics and icons meant for veneration, a practice that lies at the heart of Orthodoxy. ${ }^{55}$ In order to gain a deeper understanding of what formed Warhol's relationship with the visual image, an examination of the veneration of icons is essential. The following is an exploration of the Byzantine iconographer's role in the creation of icons, as well as the meaning and function of religious imagery in prayer and worship.

\footnotetext{
${ }^{50}$ Mango, Byzantine Architecture, 61.
}

${ }^{51}$ Marilyn Stokstad, Art History: Medieval Art (Upper Saddle River, New Jersey: Pearson Prentice Hall, 2009), 255.

${ }^{52}$ Leonid Ouspensky and Vladimir Lossky, The Meaning of Icons (Crestwood, NY: St. Vladimir's Seminary Press, 1982), 67.

${ }^{53}$ Stokstad, Art History: Medieval Art, 259.

${ }^{54}$ Barford, The Early Slavs, 216-217.

${ }^{55}$ Elizabeth Zelensky and Lela Gilbert, Windows to Heaven/Introducing Icons to Protestants and Catholics (Grand Rapids, Michigan: Brazos Press, 2005), 25. 


\section{Chapter III: Icons and the Veneration of Images}

I think [Byzantine art] was a pretty strong influence. Any of us Byzantine Catholics grew up seeing the art all of the time. Andy and the family were no different. They went to their church pretty regularly and they were always surrounded by the icons especially on the iconostasis.

$$
\text { James Warhola }{ }^{56}
$$

In contrast to Western Catholic churches where works of art are intended to cultivate a reverent atmosphere for worship, Byzantine churches emphasize the veneration of the visual image. The religious icon engages the viewer; its function is nearly equivalent to that of Scripture. ${ }^{57}$ Icons are visual representations of Christ, Mary, angels, or saints. These images are most commonly painted on wood, but also appear as mosaics, frescoes, or portraits in metal. $^{58}$ In contrast to the use of three-dimensional statues in the West, the East favors imagery that is two-dimensional and flat; perhaps this is because statues are too reminiscent of ancient Greek gods. ${ }^{59}$ As liturgical art, icons are an essential part of the religious service; they are expressions of the historical Church, its traditions, and Scripture. Iconographers were more concerned with capturing the essence and spirit of the person or event portrayed rather than an exterior resemblance of the subject. ${ }^{60}$

Unlike the religious art of the Renaissance, Byzantine icons are not personal works of art that seek to express an individual's point of view; rather, they invite the viewer to become familiar with God's manifestation of beauty rather than a human interpretation of it. ${ }^{61}$ From

\footnotetext{
${ }^{56}$ As quoted by Warhol's nephew James Warhola in an e mail interview with the author, February 25 ,
} 2008.

${ }^{57}$ Bennett-Carpenter, “The Divine Simulacrum Of Andy Warhol: Baudrillard's Light On The Pope of Pop's 'Religious Art'” (accessed February 2, 2008), http:/www.jcrt.org/archives/01.3/carpenter.html.

${ }^{58}$ Cory and Hollerich, The Christian Theological Tradition, 198.

${ }^{59}$ Adrian Fortescue, "Veneration of Images," Catholic Encyclopedia (accessed May 11, 2009), http://www.newadvent.org/cathen/07664a.htm.

${ }^{60}$ Sr. Marcia Vinje, "Icons” (accessed February 22, 2008), http://campus.udayton.edu/mary/images/icons/maria.jpg.

${ }^{61}$ Vinje, “Icons," http://campus.udayton.edu/mary/images/icons/maria.jpg. 
the beginning, icon-making was a communal endeavor; paintings were passed from one pair of hands to another. The artist's role and status were dependent upon the hierarchy of the workshop. At the head was the master, who often only intervened with his own brush in the final stages. He was both the controlling mind behind artistic production and the supervisor. This coordinated division of labor allowed for an extraordinary number of commissions from patrons.$^{62}$ In Byzantine icon art, works of individual artists with or without collaborators are generally unsigned since iconographers are but insignificant "machines" of God. ${ }^{63}$

Iconographers practice challenging spiritual disciplines as they write icons, fasting and praying before they begin. In the Russian language, the verbs to paint or to draw are only used in connection with secular painting, even if the subject matter is religious. Therefore, iconographers do not paint icons - they write them. Rather than record or copy images of an inner psychological world or a "real" world, the iconographer captures a certain aspect of the story of salvation, using images rather than words. ${ }^{64}$ The spiritual quality of icons is inherited from historical traditions of the early Church. The first and most famous icon was brought to Constantinople in 574 from the Cappadocian town of Kamoulianai. The Mandylion of Edessa was a cloth imprinted with what was believed to have been an image of Christ's countenance, or The Holy Face. The Kamoulianai icon was an unmanufactured type known as archeiropoietos - an "image not made with hands." Thought to have been the result of a miracle, it was created by divine agency; it became the prototype of all other icons of The Holy Face (figure 2). ${ }^{65}$

\footnotetext{
${ }^{62}$ Martin, Sacred Doorways: A Beginner's Guide to Icons, 32-34.

${ }^{63}$ Raymond M. Herbenick, Andy Warhol's Religious and Ethnic Roots: The Carpatho-Rusyn Influence on His Art (New York, Ontario, United Kingdom: The Edwin Mellen Press, 1997), 65.

${ }^{64}$ Zelensky and Gilbert, Windows to Heaven/Introducing Icons to Protestants and Catholics, 24.

${ }^{65}$ Angold, Byzantium: The Bridge from Antiquity to the Middle Ages, 28.
} 
In most Byzantine Catholic churches, the central doors of the iconostasis, known as the "Royal Doors," are decorated with icons of the Annunciation and the four evangelists (Matthew, Mark, Luke, and John), symbols of the Incarnation of Christ and his Word; mysteries of Word and sacrament are communicated through those doors during liturgical celebrations. The side doors, known as the "deacon's doors," bear images of the protodeacon and martyr St. Stephen, as well as the archangels Michael or Gabriel. Since deacons are considered to represent the angels of the heavenly Liturgy, the archangels are depicted in Byzantine diaconal vestments. To the right of the Royal Doors there is an icon of Christ Pantocrator (figure 3), to the left, one of the Mother of God, or Theotokos, bearing the Christ Child (figure 4). Over the doors there is often a depiction of The Last Supper, or The Communion of the Apostles (figure 5). Other images, depending on the size of the screen, may include the feast of the patron saint of the church, the Twelve Great Feasts, or the Twelve Apostles, arranged according to a prescribed order and symbolism. ${ }^{66}$

On the iconostasis, icons are organized according to fixed rules. The more important the subject, the higher it is placed in the space; and the more central the theological concept depicted, the closer it is placed to its center. Since the iconostasis is in front of the altar, one of the most important spaces in the church, it is a fitting place for an icon of Christ Pantocrator which means "Christ, the ruler of all." In addition to the iconostasis, Christ Pantocrator also appears inside the dome, the "Vault of Heaven," which is the highest point of the church. Christ Pantocrator icons are similar to Western depictions of Christ sitting on a throne "in Majesty." By the fifteenth-century, Humanism, a major intellectual force in Renaissance Europe, favored a more accessible depiction of Christ, either as a charming

\footnotetext{
${ }^{66}$ McBrien, The Harpercollins Encyclopedia of Catholicism, 751.
} 
infant or a suffering Everyman on the cross. For Eastern Rite Christians, however, Christ Pantocrator remains one, if not the most significant iconographic subjects. ${ }^{67}$

The earliest example of an icon of Christ Pantocrator is located at St. Catherine's Monastery in Sinai, dating from the sixth-century (figure 3); it may be modeled after an archeiropoietai type such as the Mandylion icon. ${ }^{68}$ Because an icon must convey meaning, faces and hands communicate much of the icon's message. In the Sinai Christ Pantocrator, there is a visible difference between the left and the right side of Christ's face. The right side of his face, the side of blessing, is calm, while the left side, the side of judgment, is stern. Although his eyes do not confront the viewer directly, the image is a stark reminder that the last judgment should be feared because it will be absolutely just, although tempered by mercy and understanding. The index finger of the left hand, countering the sideways glance of his eyes to the left, points forcefully to the right; his left fingers are bent in a gesture of blessing, while at the same time, Christ points toward himself. In addition to facial expressions and gestures, hand-held objects are also significant. The Pantocrator holds a book, either closed or open. When closed, it is the Book of Judgment to be opened at the Last Judgment; when open, an inviting verse is revealed such as "Come unto me, all ye that labour and are heavy laden, and I will give you rest." The Sinai Christ Pantocrator is meant to represent an awe-inspiring King and Judge, so the book is closed. By the fourteenthcentury, the Pantocrator became a merciful redeemer, who holds an open book with a positive verse for all to see. ${ }^{69}$

In Byzantine icons, gold was used to express the eternal light of God; it gleams from halos, from the robes of the glorified Christ, and from the backgrounds, indicating a radiance

\footnotetext{
${ }^{67}$ Zelensky and Gilbert, Windows to Heaven/Introducing Icons to Protestants and Catholics, 107, 128.

${ }^{68}$ Angold, Byzantium: The Bridge from Antiquity to the Middle Ages, 85.

${ }^{69}$ Martin, Sacred Doorways: A Beginner's Guide to Icons, 107, 150-151.
} 
of pure light. Most icons dispense with objects in the background and show a saint against a sheet of gold, because he or she is living in the light of God. ${ }^{70}$ The gold of the Christ Child's robe in the eleventh-century icon of Virgin of Vladimir (figure 4) bespeaks his divinity, while Mary's somber-hued clothing recalls the weeds of mourning. ${ }^{71}$ The ornate gold stars on her veil and shawl seem to proclaim Christ's virgin birth. In the crook of her arm, Mary cradles her son, who is shown as a small adult rather than an infant. She extends the fingers of her other hand toward him, as if she is presenting him to the entire world. ${ }^{72}$ Christ's eyes are fixed on his mother, while Mary's gaze is focused beyond the viewer, as if she is transfixed by a vision of things to come. ${ }^{73}$

The Virgin of Vladimir represents an icon type known as Virgin Hodegitria, meaning "The one who shows the way."74 It is an iconic representation of her words "Whatsoever he saith unto you, do it," at the wedding at Cana, during which Christ performed his first miracle, at his mother's request. ${ }^{75}$ The Hodegitria icon teaches the Incarnation; it refers to the moment when the divine united with humanity. ${ }^{76}$ The doctrine of the Incarnation upholds the paradoxical mystery that Christ is one person (hypostasis) possessing both a divine and human nature. ${ }^{77}$ In adoring the humanity of Christ, Byzantine Catholics venerate his mother, Mary, from whom he received his human nature. Her words at Cana did much

\footnotetext{
${ }^{70}$ Martin, Sacred Doorways: A Beginner's Guide to Icons, 48, 216.

${ }^{71}$ Widow's weeds were clothes worn by a widow during a period of mourning for her husband; see Zelensky and Gilbert, Windows to Heaven/Introducing Icons to Protestants and Catholics, 56.

${ }^{72}$ Martin, Sacred Doorways: A Beginner's Guide to Icons, 169.

${ }^{73}$ Zelensky and Gilbert, Windows to Heaven/Introducing Icons to Protestants and Catholics, 56.

${ }^{74}$ The Hodegoi were guides who led blind pilgrims to a miraculous spring near Constantinople. See Martin, Sacred Doorways: A Beginner's Guide to Icons, 169.

${ }^{75}$ John 2:5 (KJV). See Martin, Sacred Doorways: A Beginner's Guide to Icons, 169.

${ }^{76}$ Martin, Sacred Doorways: A Beginner's Guide to Icons, 169.

${ }^{77}$ McBrien, The Harpercollins Encyclopedia of Catholicism, 659.
} 
more than point to the authority of Christ. When people voiced their concerns about the lack of wine at the wedding feast, they approached Mary rather than Christ. After she sought his advice, Mary instructed the others to "do as he tells you;" consequently, the role of the Virgin became that of intercessor between others and her son. ${ }^{78}$ The early Church was forced to defend these concepts in a series of councils, which will be discussed later.

Icons play a central role in all Orthodox worship; in addition to churches, they adorn private homes, and are carried as devotional aids, as a Roman Catholic might carry a rosary. Byzantine Catholics burn incense before icons and light candles to honor them; they carry them in procession, prostrate before them, and at times kiss them. ${ }^{79}$ For Christians, the Church is the body of Christ, and it is composed of all its members, both living and dead. It is to the saints depicted in icons, including the Virgin Mary, that pleas for intercession with God are directed. ${ }^{80}$ Icons are an essential part of the Byzantine Liturgy, which embodies the ceremonial vision of Byzantine Catholicism. $^{81}$

\section{Chapter IV: The Liturgy of St. John Chrysostom}

\section{St. John Chrysostom (349-407), "the golden mouthed," was a Patriarch of}

Constantinople, and a Doctor of the Church. His skull, encased in an ornate silver box, was venerated as a holy relic after his death in the fifth-century; it was said to have been one of the holiest relics of the ancient monastery at Mount Athos. ${ }^{82}$ The most prolific of the Church Fathers, he wrote homilies that often stirred the congregation of the Hagia Sophia to tears and

\footnotetext{
${ }^{78}$ Zelensky and Gilbert, Windows to Heaven/Introducing Icons to Protestants and Catholics, 28-29.
}

${ }^{79}$ Cory and Hollerich, The Christian Theological Tradition, 199-200.

${ }^{80}$ Zelensky and Gilbert, Windows to Heaven/Introducing Icons to Protestants and Catholics, 29.

${ }^{81}$ Cory and Hollerich, The Christian Theological Tradition, 200.

82 The word Chrysostom means "the golden mouthed." See Patrick W. Carey et al. "Chrysostom, John, Saint, Patriarch of Constantinople” (accessed March 18, 2008), http://vnweb.hwwilsonweb.com. 
applause. ${ }^{83}$ The Liturgy Chrysostom wrote over 1,600 years ago was the one celebrated at the Warhola family church in Pittsburgh, St. John Chrysostom Byzantine Catholic Church, and it is the one regularly used in Byzantine churches around the world today.

The primary function of any Byzantine church is to provide a physical space for believers to participate in the celebration of the Eucharist (Holy Communion.) ${ }^{84}$ It is the sacramental celebration of the Paschal Mystery; in other words, Christ's death and resurrection. It occurs in a spirit of praise and thanksgiving for all that God has done and continues to do. During the Eucharist, the Holy Spirit is called down on the congregation that it might become the Body of Christ, the people of God. ${ }^{85}$ The church, as the site of the Divine Liturgy, is a paradox. While it is a physical place, decorated with beautiful and precious icons, frescoes, and mosaics, it is also a spiritual place, a fragment of eternity that exists outside of space and time. During the celebration of the Eucharist, there are no "then" and no "now," no "mine" and no "yours," no "inside" and no "outside." In an attempt to depict a transfigured reality, all perception is suspended in the face of eternity. ${ }^{86}$

The Liturgy begins with an Enarxis (Opening) consisting of prayers, hymns, and responses. The Monogenes (Only-begotten) chant is part of the second hymn; it is an expression of Orthodox faith in Christ as one person in two natures. Readings from Scripture follow, beginning with the Little Entrance (a procession of clergy bearing a book of scriptural readings) and the Trisagion hymn, another expression of Orthodox faith in the Holy Trinity. The Mass continues with two readings from the New Testament, a passage from one of the Gospels, and a passage from one of the Epistles (letters). A sermon is

\footnotetext{
${ }^{83}$ McBrien, The Harpercollins Encyclopedia of Catholicism, 313.

${ }^{84}$ Zelensky and Gilbert, Windows to Heaven/Introducing Icons to Protestants and Catholics, 125.

${ }^{85}$ McBrien, The Harpercollins Encyclopedia of Catholicism, 481.

${ }^{86}$ Zelensky and Gilbert, Windows to Heaven/Introducing Icons to Protestants and Catholics, 126-127.
} 
sometimes delivered at point in the ceremony, followed by the Great Entrance, which is another procession of clergy, but this time they carry liturgical fans, incense, and the bread and wine to be consecrated later in the Mass. They are accompanied by the singing of the Cherubic Hymn. The Great Entrance is understood as a dramatic reenactment of Jesus' triumphal entrance into Jerusalem and his funeral procession. ${ }^{87}$

After another prayer and the recitation of the Creed, the priest prays the Eucharistic Prayer, or Anaphora, with some intermittent congregational singing. During the Anaphora, the priest and the congregation exchange the following dialogue:

Priest: $\quad$ The grace of our Lord Jesus Christ and the love of God the Father and the communion of the Holy Spirit be with you all.

Congregants: And with your spirit.

Priest: Let us lift up our hearts.

Congregants: We lift them up to the Lord.

Priest: Let us thank the Lord.

Congregants: It is proper and right. ${ }^{88}$

After the priest delivers a monologue rejoicing in the mystery of God's interaction with humanity, the climax of the Orthodox Liturgy takes place: the bread and wine are consecrated and distributed to worshippers. Another prayer follows, then a group recitation of the Lord's Prayer. While the choir sings, further prayers and blessing conclude the service. All are then invited, whether they have received communion or not, to come forward before the iconostasis to receive a portion of the antidoron from the priest, bread that is blessed for the journey back "into the world." 89

${ }^{87}$ Cory and Hollerich, The Christian Theological Tradition, 200-201.

${ }^{88}$ Cory and Hollerich, The Christian Theological Tradition, 201.

${ }^{89}$ Antidoron, which means "in place of the gift," is unconsecrated blessed bread left over from the Prosphoras (Eucharistic loaves) prepared during the Prothesis (Eucharistic prayer) for use in the Byzantine Rite Mass. It is distributed to those who do not receive Communion; it is "in place of the (consecrated) gifts." See McBrien, The Harpercollins Encyclopedia of Catholicism, 66. See also Cory and Hollerich, The Christian Theological Tradition, 201-202. 
The sacrament of the Last Supper, sometimes referred to as the "Mystical Supper," is represented above the central Royal Doors, immediately above where communion takes place (figure 6). ${ }^{90}$ The Royal Doors are opened during the Liturgy for the sacrament to be delivered to the members of the congregation. ${ }^{91}$ The Last Supper scene continues down from the icon to the assembly as communion is served, and unites them to one another, making them participants in His body and His divinity. The effect of the Liturgy has always been heightened with visual imagery; in the words of the twentieth-century Byzantine scholar Otto Demus, "The whole interior of the church becomes one vast icon framed by its walls." response to the individual images are guided and controlled by the Liturgy, creating a highly emotional atmosphere. Icons help worshippers to visualize Christ's life and passion, the prophets, the apostles, the evangelists, and the saints and martyrs. For many years, the veneration of icons was the cause of controversy, but the subordination of images to the Liturgy guarded against the danger that images might become the focus of magical or superstitious practices. ${ }^{93}$

\section{Chapter V: Iconoclasm}

During the rule of Constantine, a universal gathering of Christian bishops known as an ecumenical council was established to resolve urgent issues affecting the Church. From 325 to 787 , seven ecumenical councils were held; their teachings are recognized as dogma by all Christians. The topics addressed by the councils fall into three categories: the nature of the

\footnotetext{
${ }^{90}$ Ouspensky and Lossky, The Meaning of Icons, 68.

${ }^{91}$ Martin, Sacred Doorways: A Beginner's Guide to Icons, 75.

${ }^{92}$ Cory and Hollerich, The Christian Theological Tradition, 198.

${ }^{93}$ Cory and Hollerich, The Christian Theological Tradition, 198. See also Angold, Byzantium: The Bridge from Antiquity to the Middle Ages, 134.
} 
Trinity, the understanding of Jesus as both human and divine, and the use of icons. ${ }^{94}$ Those who venerated icons - iconodules - saw them as fundamental to the authentic profession of the Christian faith. ${ }^{95}$ If Jesus was truly human, they reasoned, and in him God had become visible, how could one object to representing Him? After all, the first maker of images was God, who created humans in the divine image. ${ }^{96}$ Their opponents - iconoclasts - considered the veneration of icons as superstitious, and even idolatrous. A recurring common argument used against the veneration of icons is based on the second commandment which prohibits graven images. The iconoclasts stressed the invisibility and incomprehensibility of God, referring to Exodus 3, in which God speaks to but does not appear to Moses. The iconodules responded that because of the Incarnation, God in Himself could not be portrayed, but God incarnate was seen and so could be depicted. ${ }^{97}$ The iconoclast controversy continued for centuries. ${ }^{98}$

Finally, the second Council of Nicea, in 787, ruled in favor of the iconodules and affirmed the legitimacy of icons and their veneration. ${ }^{99}$ The council distinguished between worship in the strict sense, latria, due only to God, and veneration, dulia, which is given to images. ${ }^{100}$ The council's decree stated:

We declare that we defend free from any innovations all the written and unwritten ecclesiastical traditions that have been entrusted to us. One of these is the production of representational art . . a as it provides confirmation that the becoming man of the Word of God was real and not just imaginary, and as it brings us a similar benefit ... The more

\footnotetext{
${ }^{94}$ Cory and Hollerich, The Christian Theological Tradition, 163, 198.

${ }^{95}$ Roth, in Theodore the Studite, On the Holy Icons, 9.

${ }^{96}$ Gonzales, The Story of Christianity, Volume 1: The Early Church to the Dawn of the Reformation, 260.

${ }^{97}$ Roth, in Theodore the Studite, On the Holy Icons, 9.

${ }^{98}$ Gonzales, The Story of Christianity, Volume 1: The Early Church to the Dawn of the Reformation, 260.

${ }^{99}$ Cory and Hollerich, The Christian Theological Tradition, 198.

${ }^{100}$ Gonzales, The Story of Christianity, Volume 1: The Early Church to the Dawn of the Reformation,
} 260. 
frequently they are seen in representational art, the more are those who see them drawn to remember and long for those who serve as models, and to pay these images the tribute of salutation and respectful veneration. ${ }^{101}$

Because distinctions between latria and dulia were difficult to discern in Latin, the decisions of Nicea were not well received in the West. The iconoclasts regained power eventually, which led to the destruction of religious images. In 843 , images were ultimately restored when the Roman Empress Theodora reinstated the veneration of icons, an event that is still celebrated on the first Sunday of Lent by many eastern churches as the "Feast of Orthodoxy." 102

Divided by religion, Islam, Byzantium, and Latin Christendom had little in common by the end of the ninth-century. Islam, which developed in the seventh-century, is staunchly monotheistic and holds a strict prohibition on imagery. The Byzantines were contemptuous of Latin Christianity, viewing themselves as the chosen people of the New Testament. Western Catholics developed an identity around the pope as the successor of St. Peter. ${ }^{103}$ The reinstatement of icons lasted until 1204, when Christian crusaders from the West occupied Constantinople. Byzantine rule was restored in 1261 and ended with the empire's fall to the Ottoman Turks in $1453 .{ }^{104}$ A touchstone of the conflicts among the medieval civilizations was their distinctive views on art for religious purposes. Islam rejected figurative art and employed calligraphy and abstract ornamentation in keeping with its austere monotheism. After the traumas of iconoclasm, Byzantium held on the belief that the image could act as a spiritual medium, while the West continued to emphasize its instructive

\footnotetext{
${ }^{101}$ Cory and Hollerich, The Christian Theological Tradition, 198.

${ }^{102}$ Lent is the forty days preceding Easter. See Gonzales, The Story of Christianity, Volume 1: The Early Church to the Dawn of the Reformation, 260-261.

${ }^{103}$ Angold, Byzantium: The Bridge from Antiquity to the Middle Ages, 134.

${ }^{104}$ Stokstad, Art History: Medieval Art, 254.
} 
function. ${ }^{105}$ After the fall of the Byzantine Empire, Russia declared Moscow the "Third Rome" and it became the center of the Eastern Orthodox Church. Byzantine icon production continues to flourish in Ukraine, Russia, and much of southeastern Europe. ${ }^{106}$

\section{Chapter VI: The Byzantine Catholic Church in Russia}

The Primary Chronicle (1040-118), the first official history of the Kievan state,

includes an account of the conversion of the Kievan Rus' to Byzantine Christianity. ${ }^{107}$ The Kievan Rus' were the people from whom present-day Eastern Slavic peoples (e.g. Ukrainians, Russians, Belorussians) descend. ${ }^{108}$ Their conversion occurred during the reign of Prince (later Saint) Vladimir (956-1015) in 988, when his envoys went to Constantinople and attended a service in the Hagia Sophia. Upon their return to Kievan Russia, they enthusiastically praised the splendor of the worship at that magnificent church. ${ }^{109}$ Accounts of the traveler's impressions of the Hagia Sophia appear in several medieval chronicles; one reads:

Then we went to Greece (sic Byzantium) and the Greeks led us to the edifices where they worship their God, and we knew not whether we were in heaven or on earth. For on earth there is no such splendor or such beauty, and we are at a loss how to describe it. We know only that God dwells there among men, and their service is fairer than the ceremonies of other nations. For we cannot forget that beauty. ${ }^{110}$

This description created a potent image of the Byzantine Rite for the prince. Vladimir then demanded the hand of Anna, the sister of the Byzantine Emperors Basil II and Constantine

\footnotetext{
${ }^{105}$ Angold, Byzantium: The Bridge from Antiquity to the Middle Ages, 144-145.

${ }^{106}$ Stokstad, Art History: Medieval Art, 254.

${ }^{107}$ Zelensky and Gilbert, Windows to Heaven/Introducing Icons to Protestants and Catholics, 127.

${ }^{108}$ McBrien, The Harpercollins Encyclopedia of Catholicism, 1319.

${ }^{109}$ Zelensky and Gilbert, Windows to Heaven/Introducing Icons to Protestants and Catholics, 127.

${ }^{110}$ Zelensky and Gilbert, Windows to Heaven/Introducing Icons to Protestants and Catholics, 127.
} 
VII. In response to the imperial call for his baptism prior to marriage, Vladimir asked Anna to bring her priests to baptize him. Prior to his conversion to the new faith, the prince lost his eyesight: ${ }^{111}$

and at this time by God's design Vladimir was suffering from an eye disease and was unable to see anything and was quite distressed and could not decide what to do. And the princess sent [a message] to him saying, "If you wish to rid yourself of this disease, then be baptized immediately; otherwise you will not be rid of this disease." Having heard this, Vladimir said, "If this is the truth, then truly the Christian God is great." And he gave orders for his baptism. And the bishop of Chersonesus along with the princess's priests instructed Vladimir, [and] baptized [him]. And soon as he laid his hand on him, he regained his sight. And Vladimir saw this sudden healing and he praised God, saying, "Now I have perceived the true God." And when his retinue saw this, many were baptized. ${ }^{112}$

His vision miraculously restored, Vladimir was baptized in the Christian church; Byzantine Rite Christianity soon became the official religion of his people. ${ }^{113}$ Combined with the reports of his envoys, his loss and recovery of sight brought the prince to the realization that seeing and believing were fundamentally linked. ${ }^{114}$

Vladimir built many churches and put great pressure on his people to accept baptism. Bringing in priests from the Byzantine Empire, he established a Greek hierarchy under a metropolitan. From the beginning, however, the Slavic tongue of Cyril and Methodius was used in worship; as a result, Russian clergy gradually replaced the Greeks. ${ }^{115}$ The majority of the population learned about the Old Testament kings and prophets, the Virgin Mary and

${ }^{111}$ Nicholas Howe, ed., Ceremonial Culture in Pre-Modern Europe (Notre Dame: University of Notre Dame Press, 2007), 64.

${ }^{112}$ Howe, Ceremonial Culture in Pre-Modern Europe, 65.

${ }^{113}$ Before Vladimir's conversion, he was a fervent pagan, following the blended beliefs of his Viking ancestors and those of the indigenous Slavic population. See McBrien, The Harpercollins Encyclopedia of Catholicism, 1319. See also Zelinsky and Gilbert, Windows to Heaven/Introducing Icons to Protestants and Catholics, 39.

${ }^{114}$ Howe, Ceremonial Culture in Pre-Modern Europe, 65.

${ }^{115}$ McBrien, The Harpercollins Encyclopedia of Catholicism, 1140. 
Jesus Christ, and the creation of the Church from oral recitation in church services and from depictions in murals and icons. Since it was Church Slavonic and not the Russian vernacular that was used, it is likely that oral communication about church teachings was difficult at best, which caused the faithful to rely heavily on visual representation. In the Byzantine and Russian traditions, the visual image, sustained by word and ritual, was the optimal way to convey the basic truths of Orthodox spirituality to the culture of Kievan Rus'. ${ }^{116}$

After the conversion of Kiev to Orthodox Christianity, Ukrainian and Russian churches were decorated by Byzantine iconographers with Russians who worked beside them. ${ }^{117}$ The most famous imported icon was the Theotokos icon of the Virgin of Vladimir (figure 4) from Constantinople (see page 17). Brought to Kiev in the twelfth-century, it has spent most of its existence in Russia. The Virgin of Vladimir's composition is based on the icon of Lovingkindness (in Russian, Umileniie), a translation of the Greek Eleousa, which carries with it connotations of mercy, compassion, pity, and tenderness. Another role of the Theotokos figure in Byzantine culture is that of palladium or ring bearer. In the Middle Ages, both Byzantine and Slavic armies carried banners bearing the image of the Theotokos as a sign of divine protection for their cause. ${ }^{118}$ The icon was said to have saved Moscow from Tamerlane in 1395 and from the Poles in 1612. During Napoleon's invasion of Russia in 1812, the Virgin of Vladimir was carried out to the troops to strengthen their morale; it was thought to have aided in the French Emperor's defeat. Often copied in Russia, there are many versions of this miracle-working icon still in existence. Its history shows close ties between Constantinople and several Russian cities, such as Kiev, Vladimir, Novgorod, and,

\footnotetext{
${ }^{116}$ Howe, Ceremonial Culture in Pre-Modern Europe, 64, 65.

${ }^{117}$ Robin Cormak, Icons (Cambridge: Harvard University Press, 2007), 94.

${ }^{118}$ Zelensky and Gilbert, Windows to Heaven/Introducing Icons to Protestants and Catholics, 62-64.
} 
especially, Moscow. ${ }^{119}$ The Vladimir Theotokos icon came to be linked with the latter; it has been housed in Moscow's Tretiakov National Art Gallery since the 1917 revolution. ${ }^{120}$ Until the time of Catherine the Great (1729-1796), Catholics in Russia were generally foreigners who lived and worshiped in segregated areas of large towns. The first partition of Poland in 1772 incorporated 100,000 Latin Catholics and 800,000 Uniates with their ancestral lands into the Russian Empire. Always hostile to those who accepted the Union of Brest, Catherine II and her successors eventually succeeded in destroying the Uniate's link with Rome and incorporating it into Russian Orthodoxy. With the end of the nineteenthcentury came the beginnings of the Russian Catholic movement, which attempted to reconcile Catholic dogma with Russian ritual and ecclesiastical tradition. Smaller in number, Byzantine Rite Russian Catholics had difficult relations with the almost exclusively Polish Roman Catholic hierarchy in Russia, but they enjoyed the support of the metropolitan of the Greek Catholics in Galicia, a historic region of western Eukraine. As a consequence of their union with the Roman Catholic Church, Byzantine Catholics underwent a trying period of liturgical and spiritual latinization, and an erosion of their religious heritage. The Russian Catholic movement did not survive the 1917 revolution and subsequent Stalinization but it continued to exist among immigrants. ${ }^{121}$

In modern times, numerous calls for restoration of eastern patrimony have come from the Holy See, calls often ignored by the Byzantine Catholics themselves, who are comfortable with their hybrid traditions and eager to distinguish themselves from their Orthodox counterparts. ${ }^{122}$ In Catholic Insight, author Natalia Shlikhta observes:

\footnotetext{
${ }^{119}$ Cormak, Icons, 94.

${ }^{120}$ Zelensky and Gilbert, Windows to Heaven/Introducing Icons to Protestants and Catholics, 64-66.

${ }^{121}$ McBrien, The Harpercollins Encyclopedia of Catholicism, 1142.

${ }^{122}$ McBrien, The Harpercollins Encyclopedia of Catholicism, 1141-1142, 205.
} 
$[\mathrm{T}]$ he church always faces the necessity of reconciling its religious identity with inescapable 'this-worldly' identities (political, national and social), adopting an attitude towards the secular authorities (political loyalty) and towards national identity and achieving and understanding of its place and role in a society (social identity). The strain amongst these identities becomes especially acute in unfavorable surroundings when the church's religious self is jeopardized, as, for instance, under a regime professing atheist ideas. ${ }^{123}$

After the Bolshevik revolution, the Orthodox and Byzantine Rite Church's quest for autonomy became quite complicated, due to the atheist character of Marxist-Leninist ideology upon which the regime based its legitimacy, coupled with its commitment to reform Soviet society according to the Marxist vision of communism that "abolishes eternal truths...abolishes all religion...instead of constituting them on a new basis." ${ }^{\text {124 }}$ Karl Marx’s ideas presented a grave threat to Christianity. Marx assumed that history is governed by simple economic forces, and did not believe in any divine or spiritual influence. Religion was seen as the "opiate of the people," keeping the lower classes passive and resigned in their economic oppression. ${ }^{125}$ Once that oppression was removed, he theorized, religion would wither away, because people would be fulfilled and would no longer need false consolation. Marx's vision was attractive in eastern European countries where workers and peasants were oppressed by an elite ruling class. ${ }^{126}$

Dependent upon their small herds of cows, sheep, and goats, Carpatho-Rusyns lived in infertile valleys on tiny plots in small villages, working as serfs for Hungarian or Polish landlords until 1848, and then as poorly paid/indebted agricultural laborers under those same landlords for several more decades. Until the twentieth-century, social and geographic

${ }^{123}$ Natalia Shlikhta, "Greek Catholic' - 'Orthodox' - 'Soviet' A Symbiosis or a Conflict of Identities?” Religion, State and Society 32 (September, 2004): 261-273.

\footnotetext{
${ }^{124}$ From the Manifesto of the Communist Party; see Shlikhta, 'Greek Catholic' - 'Orthodox' - 'Soviet' A Symbiosis or a Conflict of Identities?," 261.

${ }^{125}$ Cory and Hollerich, The Christian Theological Tradition, 394.

${ }^{126}$ Cory and Hollerich, The Christian Theological Tradition, 394.
} 
mobility was uncommon for Carpatho-Rusyns. Dominated by the demands of the agricultural seasons and the Church calendar, the majority spent their entire lives in their native or neighboring villages. The desire to earn money with which to buy land, prepare for marriage, and support a family prompted a large-scale flight of Carpatho-Rusyns to America. $^{127}$

\section{Chapter VII: Carpatho-Rusyns in America}

Carpatho-Rusyns began immigrating to the United States in the late 1870s. By the outbreak of World War I in 1914, approximately 225,000 had arrived, the largest number of Carpatho-Rusyns ever to reach America. A second wave of about 20,000 followed after the war and from World War II to the present, the numbers decreased to 10,000. Planning to return home eventually with the money they had earned in America, they temporarily settled in the northeast and north-central states, specially the coal mining region of eastern Pennsylvania, and in and around the western Pennsylvania industrial city of Pittsburgh. ${ }^{128}$ Fantasies of "the land of milk and honey" were quickly destroyed by harsh realities. While some immigrants were unable to cope with the long, hard, monotonous hours of work for little pay, others were able to earn respectable wages, and these successful immigrants wrote letters to their countrymen encouraging them to make the journey. Those who returned to their native villages bought land and were regarded as the wealthy neighbor who struck it rich in America. ${ }^{129}$

Most of the newcomers were poor peasants who had been laborers and domestic servants in their European homeland; there were few skilled artisans, professionals, or

\footnotetext{
${ }^{127}$ Magocsi, Our People: Carpatho-Rusyns and Their Descendants in North America, 10.

${ }^{128}$ Magocsi, “Carpatho-Rusyn Americans” (accessed November 15, 2009), http://www.everyculture.com/multi/Bu-Dr/Carpatho-Rusyn-Americans.html.

${ }^{129}$ Magocsi, Our People: Carpatho-Rusyns and Their Descendants in North America, 11.
} 
merchants. The United States was going through a period of rapid industrial expansion at the turn of the century, so many of these immigrants found employment as unskilled laborers in factories, mines, and steel mills. Carpatho-Rusyn women often had to supplement their husbands' income by hiring themselves out as domestics or working part-time in stores or mills. Because they intended to stay in America only temporarily, Carpatho-Rusyns typically moved into boarding houses, or company-owned houses and tenements near the mines or factories where they worked. Although often overcrowded and polluted with industrial smoke and noise, these living conditions were psychologically secure, since the majority of their neighbors were Rusyns or other Slavic and eastern European immigrants. By the 1920s, political conditions in Europe and adaption to American life convinced many CarpathoRusyns to stay in the United States. ${ }^{130}$

Like many other European immigrants, Carpatho-Rusyns were not discriminated against because of their color, but their low economic status and lack of knowledge of English segregated them from the rest of Pittsburgh society. The dialects they spoke are classified as East Slavic and are most closely related to Ukrainian. However, because their homeland is located near the borders of Slovakia, Poland, and Hungary, Carpatho-Rusyn speech has been heavily influenced by neighboring West Slavic languages such as Slovak, Polish, and Hungarian. They tended to be grouped with other Slavic and Hungarian laborers, and were often referred to by the derogatory term "Hunkies."131

Not only were Carpatho-Rusyns estranged linguistically, but their religion also set them apart. There were no Eastern Christian churches in the United States when they arrived, so they built their own, inviting priests from the European homeland. Because the immigrants expected that they would not be accepted into American society, they created various

\footnotetext{
${ }^{130}$ Magocsi, Our People: Carpatho-Rusyns and Their Descendants in North America, 13-20.

${ }^{131}$ Magocsi, "Carpatho-Rusyn Americans” (accessed November 15, 2009), http://www.everyculture.com/multi/Bu-Dr/Carpatho-Rusyn-Americans.html.
} 
religious and secular organizations that would preserve their old world culture and language. By the 1920s, however, the children of immigrants began to reject the culture of their parents and tried to assimilate fully into American life, doing everything possible to be like "regular" Americans - even at the expense of losing their ethnic and religious heritage. CarpathoRusyns were further cut off from their homeland by the economic hardships of the 1930s, World War II, and the imposition of Communist rule and its isolation behind the "Iron Curtain" after $1945 .^{132}$

In the European homeland, Carpatho-Rusyn culture and identity were synonymous with Byzantine Rite Catholic churches. Until well into the twentieth-century, all rites of passage birth/baptisms, weddings, funerals, public events - were determined by the Church calendar. ${ }^{133}$ Since religious life was so intertwined with the Carpatho-Rusyn mentality in their native lands, the first immigrants attempted to recreate a similar environment in the United States. Several generations later, their community life continues to rely almost exclusively on the individual's relation to his or her church. ${ }^{134}$ Churches not only provided a place of worship according to the Eastern Byzantine Rite, they also became centers for Rusyn-American social, educational, and cultural activity. ${ }^{135}$

The Byzantine Rite Catholic Church had difficulties maintaining traditional practices in the new homeland. The religion of the Carpatho-Rusyn immigrants was not welcomed by American Roman Catholic bishops and clergy and, under pressure from Rome, some immigrants abandoned traditional Eastern practices. After 1929, they were forced to accept the practice of celibacy for priests, and married men were no longer able to be ordained to the

\footnotetext{
132 Magocsi, "Carpatho-Rusyn Americans" (accessed November 15, 2009), http://www.everyculture.com/multi/Bu-Dr/Carpatho-Rusyn-Americans.html.

${ }^{133}$ Magocsi, "Carhpatho-Rusyn Americans” (accessed November 15, 2009), http://www.everyculture.com/multi/Bu-Dr/Carpatho-Rusyn-Americans. html.

${ }^{134}$ Magocsi, Our People: Carpatho-Rusyns and Their Descendants in North America, 22.

${ }^{135}$ Magocsi and Pop, Encyclopedia of Rusyn History and Culture, 138.
} 
priesthood. Roman Catholic criticism of the Byzantine Rite and Eastern practices resulted in "return to Orthodoxy" movements among Rusyn-American Eastern Catholics, particularly after 1891 and again after $1929 .{ }^{136}$ In an effort to "return to the ancient faith," thousands left the Church and joined the Orthodox Church. ${ }^{137}$ The division between Orthodoxy and Byzantine Rite Catholicism in the European homeland has continued among CarpathoRusyns and their descendants in the United States. ${ }^{138}$

By the 1920s, there was a strong tendency, encouraged by the Orthodox Church, to consider Rusyns as little more than a branch of the Russian nationality. This history is why Carpatho-Russian became a popular term to describe the group. By the 1950s, two more identities were added, Slovak and Ukrainian. By the 1970s, there was a return to the original Rusyn identity - the idea that Carpatho-Rusyns are not Russian, Slovak, or Ukrainian, but rather a distinct nationality. Carpatho-Rusyn culture in the United States has been expressed through family and fraternal organizations, but especially through the Church. It is the religious context that is most important as a cultural identifier. According to historian Paul Magocsi, "the role of religion is so great that in the mind of most immigrants and their descendants, Carpatho-Rusyn culture is virtually synonymous with the Eastern-Rite Liturgy... and the attendant rituals and family celebrations...associated with the church."139

Like so many immigrants from the Carpatho-Rusyn region, religion played a significant role in the lives of Warhol's parents, Ondrej Warhola (1888-1942) and Julia Zavacky (18921972). After the couple married and left their homeland to start a new life in America, they

${ }^{136}$ Magocsi and Pop, Encyclopedia of Rusyn History and Culture, 481.

${ }^{137}$ Magocsi, "Carhpatho-Rusyn Americans” (accessed November 15, 2009), http://www.everyculture.com/multi/Bu-Dr/Carpatho-Rusyn-Americans. html.

138 Magocsi, "Carhpatho-Rusyn Americans” (accessed November 15, 2009), http://www.everyculture.com/multi/Bu-Dr/Carpatho-Rusyn-Americans. html.

${ }^{139}$ Magocsi, Our People: Carpatho-Rusyns and Their Descendants in North America, 22. 
held on to their Eastern Christian traditions and continued to observe the calendar of their faith. ${ }^{140}$

\section{Chapter VIII: The Warholas Come to Pittsburgh}

I think prayer really helped [Warhol] through a tough life and religion formed his character.

$$
\text { John Warhola }{ }^{141}
$$

Both Ondrej and Julia came from hard-working peasant families - shepherds and farmers who at times struggled to survive. ${ }^{142}$ The couple married in 1909, and three years later in 1912, before the First World War, Ondrej left Mikova for Pittsburgh, Pennsylvania, to look for work. He soon found employment on construction sites and in industrial centers throughout the eastern United States. Unable to follow until after the war, Julia joined her husband in 1921 and they soon started a family. To help support their three sons, Paul (b. 1922), John (1925-2010), and Andrew (1928-1987), Julia sold her floral handcrafts door-todoor and cleaned houses. The Warholas lived in Soho, a working-class neighborhood of Pittsburgh bordered by Irish factory workers who openly expressed their hostility towards their Ruthenian neighbors for "stealing their jobs." 143 Though cultural tensions and financial hardships complicated their lives, the family found solace at St. John Chrysostom Eastern Rite Russian Greek Catholic Church, now St. John Chrysostom Byzantine Catholic Church, in Pittsburgh's Ruska Dolina (Rusyn Valley), where they participated in the Eastern Rite Mass said in Church Slavonic. ${ }^{144}$

\footnotetext{
${ }^{140}$ The Warholas were devout Byzantine Catholics who followed the dictates of the Julian Calendar, such as celebrating Christmas on January 6 rather than December 25. See Victor Bockris, Warhol: The Biography (London: Da Capo Press, 1989), 16.

${ }^{141}$ As quoted by Warhol's older brother, John Warhola. See Bockris, Warhol: The Biography, 29.

${ }^{142}$ Bockris, Warhol: The Biography, 25.

${ }^{143}$ Bob Colacello, Holy Terror: Andy Warhol Close Up (New York: Cooper Square Press, 1990), 14.

${ }^{144}$ Bourdon, Warhol, 16-17.
} 
Throughout his life, Warhol was particularly close to his mother. Although difficult to understand (she never mastered English), Julia was an excellent storyteller and frequently talked to her son about her life in Mikova, and the Bible. When the family moved from Soho to the South Oakland section of Pittsburgh in 1934, Julia's broken English, religion, and dress alienated her from some of her neighbors. Despite these challenges, Julia's commitment to her faith was unwavering; she attended Mass daily, often accompanied by her youngest son, Andy. ${ }^{145}$ Registered in Warhol's memory were the countless hours he spent in church, sitting before the monumental grid of icons on the iconostasis (figure 6). While the priests and deacons performed their sacred rites behind the screen, out of the congregation's view, Warhol contemplated the isolated figures of saints floating before gilded gold grounds stacked repeatedly across the screen, and the Last Supper icon prominently displayed over the central Royal Doors.

Catholicism has traditionally relied upon the allure of images, unlike Protestantism, which harbors a deep suspicion of the power of art and artifice. ${ }^{146}$ In Protestant culture, the ability to read the printed word takes precedence over the religious imagery that is such an intrinsic part of Catholicism. ${ }^{147}$ "I never read,” Warhol once said, "I just look at pictures.",148 In several of his early comic-strip and product paintings, the artist showed little regard for the textual elements of his appropriated newspaper sources. In Dick Tracy (1960, figure 7) and TV\$199 (1960, figure 8), Warhol intentionally chose which details to copy and blurred the

\footnotetext{
${ }^{145}$ In America, Julia continued to wear long peasant dresses and babushkas. She refused to learn English, and spoke to her family only in their native tongue, Po nasemu (in our own manner), a mixture of Hungarian and Ukrainian. See Bockris, Warhol: The Biography, 16-24.

${ }^{146}$ Paul Gilles, American Catholic Arts and Fictions: Culture, Ideology, Aesthetics (Cambridge: Cambridge University Press, 1992), 90.

${ }^{147}$ Svetlana Alpers, The Art of Describing: Dutch Art in the Seventeenth Century (Chicago: University of Chicago Press, 1983), 169.

${ }^{148}$ As quoted in Andy Warhol "Giant” Size, ed. Phaidon (London: Phaidon Press Limited, 2006), 99.
} 
visual information that seemed less important - the text. Formal decisions such as these were informed by more than fragmented images in the comic and classified sections of the newspaper. The Ruska Dolina of Warhol's childhood was steeped in a culture whose veneration for its saints was not expressed in the written word, but rather in icons. ${ }^{149}$

Icons are a visual language; they are created by traditionally-trained iconographers through a sacred process that is highly valued and respected by the faithful. For Byzantine Catholics, the Church is the body of Christ, composed of all its members, both living and dead. All are present, but it is to the saints depicted in icons, including the Virgin Mary, that prayers for intercession are directed. ${ }^{150}$ Icons exist beyond time and space because they are believed to be doors or windows into the eternal realm. ${ }^{151}$ These "channels of grace" are fixed in the mind of the believer and the emotional response elicited by their spiritual presence is never absent from memory; this is how Warhol experienced the visual image.

It was not until his death in 1987 that the public learned what lay beneath the surface of Warhol's ambiguous façade. In his eulogy for Warhol at a memorial service just after the artist's death, art historian John Richardson stated:

Never forget that Andy was born into a fervently Catholic family and brought up in the fervently Catholic Ruska Dolina, the Ruthenian section of Pittsburgh. As a youth, he was withdrawn and reclusive, devout and celibate; and beneath the disingenuous public mask that is how he at heart remained. Thanks to his adored mother, Julia, Andy never lost the habit of going to Mass more than was obligatory. As fellow parishioners will remember, he made a point of dropping in on his local church, St. Vincent Ferrer, several days a week until shortly before he died. ${ }^{152}$

${ }^{149}$ Tony Scherman and David Dalton, Pop: The Genius of Andy Warhol (New York: HarperCollins Press, 2009), 4.

${ }^{150}$ Zelensky and Gilbert, Windows to Heaven/Introducing Icons to Protestants and Catholics, 29.

${ }^{151}$ Zelensky and Gilbert, Windows to Heaven/Introducing Icons to Protestants and Catholics, 30.

152 Eleanor Heartney, Postmodern Heretics: The Catholic Imagination in Contemporary Art (New York: Midmarch Arts Press, 2004), 27-28. 
Though Catholicism remained a powerful influence up until the end of his life, few knew about the well-concealed religious and cultural background that so deeply shaped the artist's psyche and his art. ${ }^{153}$

Recognizing his youngest son's potential, Ondrej made it clear shortly before his death in 1942 that Andy would have a college education. A large portion of Ondrej's hard-earned savings was set aside for Andy to attend Carnegie Institute of Technology, now CarnegieMellon University, in September of 1945. After graduation, Warhol moved to New York with classmate and artist Philip Pearlstein (b. 1924). ${ }^{154}$ New York must have seemed worlds away from Pittsburgh. Warhol relished the opportunity to leave Steel City behind and explore the more glamorous industries of advertising, music, and fashion - the mechanisms of popular culture.

\section{Chapter IX: American Pop}

When I first saw Warhol, Lichtenstein, Rosenquist, Oldenburg, and Wesselmann within a four-month period, I had a sitting-up-in-bed kind of thing, thinking something very strange was going on in the art world.

$$
\text { Ivan C. Karp }{ }^{155}
$$

In the waning days of Abstract Expressionism, the sensibilities of a 1960s audience accustomed to thinking of art as an intimate medium for conveying emotion were shaken by the appearance of a strange new phenomenon: Pop art. Originating in late 1940s England, Pop later emerged in New York as a result of the dramatic cultural changes that occurred in America after the Second World War. ${ }^{156}$ By the mid-1950s, the armed forces had been

\footnotetext{
${ }^{153}$ Gilles, American Catholic Arts and Fictions: Culture, Ideology, Aesthetics, 280. See also Charles Stuckey et al., Andy Warhol: Heaven and Hell Are Just One Breath Away! (New York: Rizzoli, 1992), 140.

${ }^{154}$ Bourdon, Warhol, 7-25.

${ }^{155}$ As quoted in Rosalind Constable, "New York's Avant Garde and How It Got There." New York Herald Tribune (May 17, 1964): 10.

${ }^{156}$ Lucy Lippard, Pop Art (London: Thames \& Hudson Ltd., 1966), 9.
} 
demobilized and the Cold War with the Soviet Union had commenced. A booming postwar economy emerged in which money was freely spent on new tract homes, big shiny cars, and a tantalizing assortment of consumer goods. Advertisements saturated the mass media, which was becoming a ubiquitous presence in people's lives. Until this time, long-held American values such as thrift and frugality dictated that money be saved or invested. After the paralyzing poverty of the Great Depression and the deprivations of the Second World War, the middle class eagerly began to pay for goods and services that promised pleasure, convenience, and excitement. ${ }^{157}$ This is the socio-economic climate in which Warhol's career began.

Though Warhol's family had emigrated from an area of east-central Europe that was impacted by communism more than consumerism, the artist grew up in the heart of industrial America and became an enthusiastic capitalist. ${ }^{158}$ Throughout his career, Warhol viewed his paintings as commodities produced in a factory rather than unique, hand-crafted works of art. "Business is the step that comes after art," he once said, "I started as a commercial artist. I want to finish as a business artist." 159 An award-winning illustrator in the 1950s, Warhol transitioned from commercial art to fine art during the following decade and dared to make the production of art inseparable from its marketing. ${ }^{160}$ Regardless of the theme, Warhol's work reflected the omnipresent mass media that served consumerism. ${ }^{161}$

\footnotetext{
${ }^{157}$ Joseph R. Conlin, The American Past: A Survey of American History (Bellmont: Thomson Wadsworth, 2009), 748-749.

${ }^{158}$ Journalist H.L. Menchen referred to Pittsburgh as "the very heart of industrial America." See Bockris, Warhol: The Biography, 12-19.

${ }^{159}$ Warhol called his studio "The Factory."

${ }^{160}$ Sebastian Smee, "Debating the political artistry of a Pop icon," The Boston Globe, October 7, 2008, accessed November 9, 2009, http://www.boston.com.

${ }^{161}$ Stuckey et al., Andy Warhol: Heaven and Hell Are Just One Breath Away!, 140.
} 
In the summer of 1963, Warhol and three companions embarked on a 3,000 mile road trip from New York to California. As he traveled west for the first time, the artist marveled at the increasing number of billboard advertisements strewn along the nation's highways. After the trip, Warhol realized that “once you 'got' Pop, you could never see a sign the same way again. And once you thought Pop, you could never see America the same way again." ${ }^{162}$ From childhood and into adulthood, ever-present mass media images newspapers, films, pulp magazines, and billboard advertisements - profoundly shaped the artist's perception.

Historian Paul Giles observes that Warhol's iconography pursues the psychological effects of popular culture, and the implications of a Catholic spirit in American art. He argues that economically-impoverished classes tend to value popular art over high culture, and since mid-twentieth century Catholic Americans were usually less affluent, they found themselves surrounded by the more accessible icons of a mass consumer market. Justifying his own obsession with cinema rather than literature, filmmaker Martin Scorsese (b. 1942), a Roman Catholic, recalled that "I grew up in a house without books, and basically everything I learned was visual." ${ }^{163}$ Although Warhol always maintained control of his work, he refrained from writing. Not only did he not write the dialogue in his films, the text in his published books and diaries was penned by friend and writing collaborator Pat Hackett. ${ }^{164}$

Like Scorsese, Warhol's relationship with the visual image was shaped by his experience as a

${ }^{162}$ Bourdon, Warhol, 169.

${ }^{163}$ Gilles, American Catholic Arts and Fictions: Culture, Ideology, Aesthetics, 278.

${ }^{164}$ Paul Morrissey, Jed Johnson, and Pat Hackett wrote Warhol's films in the 1970s, including Frankenstein and Dracula. According to Interview editor and colleague Bob Colacello, Hackett often complained during filming and "felt she was being treated like a secretary, when she was not only writing a large portion of the dialogue but also coaching the actors after hours." See Colacello, Holy Terror: Andy Warhol Close Up, 145-146. Although she is credited as the editor, the book The Warhol Diaries was technically written by Hackett. Every morning beginning in 1976, Warhol telephoned Hackett and related the events of the previous twenty-four hours. Hackett would then record their discourse in writing, which resulted in the publication of The Warhol Diaries. See Pat Hackett, ed., The Warhol Diaries (New York: Warner Books, 1989). Warhol's book Popism: The Warhol Sixties was produced by Hackett taking dictation from Warhol. Warhol, Andy and Hackett, Pat, Popism: The Warhol Sixties (New York: HarcourtBooks, 1980). 
Catholic coming of age in 1950s America. In order to achieve his artistic goals, Warhol hid his background and manufactured a public persona that removed all traces of his religious and cultural identity.

In addition to a calculated air of detachment, Warhol had a seemingly cold, mechanical method of working that debunked Modernist protocols and infuriated the art critics of the post-Abstract Expressionist era. By overseeing the production of large numbers of paintings like the foreman of a factory, Warhol was mimicking the methods of mass icon production according to a fixed pattern by East Slavic masters and their assistants.

\section{Chapter X: Like a Machine}

The reason I'm painting this way is that I want to be a machine, and I feel that whatever I do and do Machine-like is what I want to do. Andy Warhol ${ }^{165}$

From the beginning of his career, Warhol recruited the help of assistants to expedite his numerous studio projects. Later, in Warhol's "Factory," paintings were produced in an almost assembly line method of mass production. ${ }^{166}$ Participation was essential to Warhol's artistic process; he hated working alone and depended on friends and colleagues to paint backgrounds, fill in details, and suggest ideas for future projects. Rather than painting images by hand, Warhol used and reused stencils in the early years, before he turned to silkscreens, with the help of assistant Nathan Gluck (1918-2008) in $1962 .{ }^{167}$ Warhol's factory system was not by any means new; in the centuries-old tradition of East Slavic icon

\footnotetext{
${ }^{165}$ As quoted in G.R. Swenson, "What is Pop Art?: Answers from Painters, Part I" ARTnews (November, 1963): 26.

${ }^{166}$ Warhol was so attracted to shiny silver and gold surfaces that he asked Billy Name, a hairdresser and lighting man with whom he worked, to cover every surface of his Factory with silver paint and tinfoil. See Bockris, Warhol: The Biography, 25.

${ }^{167}$ Nathan Gluck worked as Warhol's assistant from 1955 through the early 1960s.
} 
painting a version of a factory system was used even before the masters of the Renaissance (see page 15). ${ }^{168}$

Traditional icon painting is a communal enterprise, and relies on the use of stencils for drawing repetitive shapes. Saints are often depicted wearing robes decorated with precisely repeated patterns, as though they had been cut from wallpaper. ${ }^{169}$ Warhol and his assistants created actual wallpaper in 1966 by repeatedly printing a pattern of pink cow heads on a bright gold ground (figure 9). With its domestic connotations and decorative "kitsch" appearance, Cow Wallpaper (1966) was seen as an expression of Warhol's dissatisfaction with conventional painting at the time but, taking the artist's relationship with Byzantine icons into account, he was simulating the precisely repeated patterns of the imagery with which he was so familiar.

When iconographer and theologian Pavel Florensky (1882-1937) was questioned about the mechanical, mass production of Byzantine icons, he replied:

[A] 'first appeared' icon is never conceived as an act of solitary creativity; rather, every icon belongs in essence to the collective work of the Church; and even if, by chance, a particular icon is fashioned entirely by one single master, some ideal participation of other iconpainters is always implied... In fine arts, an artist's stylistic uniqueness demands the absence of other people; in iconpainting, the primary goal is always the clarity of a collectively carried and transmitted truth. ${ }^{170}$

Warhol seldom signed his works; perhaps the artist was aware that in the Byzantine tradition, works are generally unsigned since icon painters are but insignificant "machines of God."171 Warhol's desire to produce mechanically-made paintings - to "be a machine" - was expressed throughout his career. The artist had an "untouched by human hands" method of

\footnotetext{
${ }^{168}$ Raymond M. Herbenick, Andy Warhol's Religious and Ethnic Roots: The Carpatho-Rusyn Influence on His Art (New York, Ontario, United Kingdom: The Edwin Mellen Press, 1997), 47.

${ }^{169}$ Martin, Sacred Doorways: A Beginner's Guide to Icons, 61.

${ }^{170}$ Pavel Florensky, Iconostasis (United States: St. Vladimir's Seminary Press, 1996), 134-135.

${ }^{171}$ Herbenick, Andy Warhol's Religious and Ethnic Roots: The Carpatho-Rusyn Influence on His Art, 65.
} 
painting; he thought his art magically materialized and wanted it to look that way. In order to achieve this effect, Warhol had to eliminate the sign of the artist's hand. Like a modern-day iconographer, Warhol traced and used opaque projectors, Photostats, stencils, gum-eraser stamps, and silkscreens. ${ }^{172}$

What remained constant throughout Warhol's career, whether in drawings, paintings, or silkscreens, was his fascination with simulacrum and the copied image. ${ }^{173}$ Once the artist discovered the silkscreen technique in late 1962, he ceaselessly recreated the same painting over and over again. ${ }^{174}$ Interestingly, before icon artists had the technology available to them for mechanical reproduction, icons were copied by setting up a prepared panel on an adjoining easel and painting another icon. When it was finished, there would be two "originals." Today, some churches in Russia have photographic reproductions of icons on the walls, blessed, venerated, and loved as though they are originals. Some Orthodox churches sell color reproductions to those who cannot afford original works. ${ }^{175}$ Although Warhol's affinity for simulacrum was highly criticized by those who saw the art object as a precious and unique relic, it would have been surprising if Warhol did not reproduce his work, considering his cultural background.

As a Byzantine Catholic, Warhol was well acquainted with icons of The Holy Face (figure 2). According to one legend, King Abgar of Edessa sent a message to Christ, asking him to come and heal him (see page 15). Rather than go to him in person, Christ pressed a cloth to his face - miraculously imprinting his image on it - and sent it to the King, who was healed by the sight of his countenance. The outline of the face remained on the cloth as the

\footnotetext{
${ }^{172}$ David Dalton, “America the Beautiful," in Andy Warhol "Giant” Size, ed. Phaidon (London: Phaidon Press Limited, 2006), 126.

${ }^{173}$ Scherman and Dalton, Pop: The Genius of Andy Warhol, 17.

${ }^{174}$ David Dalton, “Matinee Idols," in Andy Warhol "Giant” Size, ed. Phaidon (London: Phaidon Press Limited, 2006), 174.

${ }^{175}$ Martin, Sacred Doorways: A Beginner's Guide to Icons, 55.
} 
"image not made with hands" (archeiropoietos); it became the prototype of all icons of The Holy Face. What makes this portrait so striking is that the face is shown with no neck, as if it is an image taken from a cloth pressed to a person's face, unlike a man-made portrait which contains a face, neck, and shoulders. ${ }^{176}$

Warhol's last self-portraits of 1986 differ greatly from those he had created earlier in his career. Known as the fright-wig Self-Portraits, the haunting visage of the artist is depicted with no neck or shoulders on a 108-inch square canvas. In one version, Warhol's disembodied head - covered in a camouflage pattern - appears to float in a dark void (figure 10). Camouflage became a favorite motif in the last year of Warhol's life, appearing on selfportraits as well as a version of The Last Supper which will be discussed later. The device served as a metaphor for not only his deceptive painting practices, but a mask that conceals the private Warhol from his public persona. ${ }^{177}$ In the words of theologian Gennadios Limouris:

[T] he icon helps us to decipher every human face as an icon. For every human face is an icon. Beneath all the masks, all the ashes, every human being, however ravaged he or she may be by his or her destiny, by the destiny of history and of civilization, carries within him or her the pearl of great price, this hidden face. ${ }^{178}$

In another self-portrait created in 1986, Warhol depicted his face as a charcoal mask on a gleaming golden surface (figure 11). More than any of his paintings, this shroud-like selfportrait may suggest that Warhol was reflecting on his mortality during what ended up being the final year of his life. Moreover, it is evocative of the prototype of all Byzantine icons, The Holy Face - "the image not made with hands." Byzantine icons of this type informed Warhol's earliest celebrity portraits.

\footnotetext{
${ }^{176}$ Martin, Sacred Doorways: A Beginner's Guide to Icons, 151-152.

${ }^{177}$ Joseph D. Ketner, ed., Andy Warhol: The Last Decade (New York: Prestel Publishing, 2009), 36-37.

${ }^{178}$ Gennadios Limouris, ed., Icons: Windows on Eternity (Geneva: WCC Publications, 1990), 118.
} 
Early in his childhood, Warhol discovered the glamorous world of celebrity, wealth, and beauty in the movie magazines he collected. ${ }^{179}$ A few days after hearing of Marilyn Monroe's death in 1962, Warhol purchased a photograph taken for publicity purposes for the 1953 film Niagra and, after cropping it below her chin, had it converted without any further alteration into a silkscreen. ${ }^{180}$ Warhol produced twenty-three Marilyn portraits, including Gold Marilyn Monroe - a small image on an expansive gold field (figure 12). Most of the series was printed in black ink and hand-painted with startling bright, acidic colors rather than the somber, muted tones that one would ordinarily expect for such a somber subject.

Those who venerate icons believe that the pictures themselves have become holy, in a similar manner to the transubstantiation of bread and wine into Christ's body and blood in the Catholic celebration of the Eucharist. It was the practice of venerating pictures as sacred icons that prompted the iconoclasts to reject religious imagery, which led to the split between the Eastern and Western Churches 1,000 years ago. When asked about the influence of Byzantine iconography on Warhol's work, nephew James Warhola observed to this author that:

$[\mathrm{M}] \mathrm{y}$ uncle was highly influenced by it visually. Not just the impact of large faces on gold but the fact that the art was stylized and not realistic making the point that an interpretation of the real world by an artist supersedes trying to replicate reality which my uncle was never really into. ${ }^{181}$

In traditional icon painting, the icon must resemble its prototype since it is through this quality that the divine grace of the subject represented is transmitted, but it must also be nonrepresentational, for what it depicts is an image that is both of this world and of

\footnotetext{
${ }^{179}$ Bockris, Warhol: The Biography, 38.

${ }^{180}$ Bourdon, Warhol, 124.

${ }^{181}$ As quoted by Warhol's nephew James Warhola in an e mail interview with the author, February 25,
} 2008. 
another. ${ }^{182}$ Clearly, Warhol was not attempting to create a realistic portrait when he produced Gold Marilyn Monroe. In an apotheosis of Marilyn Monroe, the movie star's face is so abstracted that it resembles a mask, reproduced to the point that in this painting it is impossible to determine where the mask ends and where the person begins. ${ }^{183}$

What the icon painter seeks to represent is not human nature, but the sanctified human person. An earthly portrait signifies absence - a reminder of someone who has departed. An icon represents the transfigured person; a presence in the new world, a "present-ness" of those who remain living in the light of God. ${ }^{184}$ Gold Marilyn Monroe possesses a striking visual presence; the pictorial space that surrounds the movie star is profoundly deep, spraypainted in metallic gold. In Byzantine art, gold indicates a radiance of heavenly light. ${ }^{185}$ Many icons depict a solitary holy figure before a flat sheet of gold (figure 13), because the being represented is living in God's eternal light. ${ }^{186}$ In Warhol's silkscreen portrait of Monroe, the glamorous movie star has been transfigured into a new presence in a heavenly realm.

The pictorial space in Gold Marilyn Monroe makes the figure appear as if it is floating in space. Although Byzantine art is often perceived as being flat and lacking in depth, Byzantine iconographers do not intend to capture those who habitually limit themselves to the surface of things. They do not seek to make a momentary or passing impression, but to produce a permanent and continuous impact on the soul. Therefore, the representation of sacred forms according to their natural appearance is avoided. Through the use of

\footnotetext{
${ }^{182}$ Margaret Kenna, "Icons in Theory and Practice: An Orthodox Christian Example," History of Religions 24 (May, 1985): 349.

${ }^{183}$ Bockris, Warhol: The Biography, 152.

${ }^{184}$ Limouris, Icons: Windows on Eternity, 99-100.

${ }^{185}$ Martin, Sacred Doorways: A Beginner's Guide to Icons, 48.

${ }^{186}$ Martin, Sacred Doorways: A Beginner's Guide to Icons, 216.
} 
abstraction, Byzantine iconographers sought to express the spiritual reality which constitutes the highest truth. Whereas in Western art abstraction constituted an end in itself and was sought as an artistic ideal, in Byzantine art it served another purpose: the necessity to completely subordinate reality to a higher spirituality. Christ "being formed in likeness to us, deified what He received;" this deification, a theosis of human nature, is made perceptible by the iconography in Byzantine art - and is reflected throughout all of Warhol's work. ${ }^{187}$

Warhol rarely created a work of art without depicting a figure or object; an exception was the helium-filled Mylar pillows known as Silver Clouds (1966, figure 14). Warhol has been continually accused by postmodern theorists of being "a mirror" who incessantly produced media-reflexive images signifying nothing. "People are always calling me a mirror," the artist said, "and if a mirror looks into a mirror, what is there to see?", 188 A Silver Cloud represents more than a buoyant, vacuous shell; on its shiny surface is the reflection of the viewer. Because every human being is created in the image of God, according to Christian theology, the mirror-like surface of Warhol's Silver Clouds transforms the image of the viewer into a holy image.

In 1966, just four years after his first solo exhibition, the artist publically announced his retirement from painting while releasing several Silver Clouds from his studio rooftop into the New York City skyline. These floating icons possessed a spiritual reality that foreshadowed the most complex and meaningful artwork of his career; the work he produced from 1976 to 1986. Evocative paintings such as Skull (1976), Oxidation (1978), Shadows (1978), Raphael I-6.99 (1985), and The Last Supper (1986) debunk the erroneous belief that after the 1960s his work failed to resonate in the same compelling manner. Throughout

\footnotetext{
${ }^{187}$ Limouris, Icons: Windows on Eternity, 99-100.

${ }^{188}$ As quoted in Matthew Baigell, Artist and Identity in Twentieth-Century America (Cambridge: Cambridge University Press, 2001), 165.
} 
Warhol's entire body of work his style and technique reveal his lifelong connection with the beliefs and customs of Byzantine Catholicism.

\section{Chapter XI: Skulls and other Precious Relics}

Andy came back from Paris in 1976 and handed me a skull. He said 'Shoot this, do pictures. I want to do this. Do you like the idea?' I said 'Yeah, it's like the classic still life; only there won't be anything else, there will just be this big skull - and it's everybody's portrait in the world.

$$
\text { Ronnie Cutrone }{ }^{189}
$$

Warhol spent much of the 1970 s relentlessly pursuing commissioned portraits of the rich and famous, drawing significant criticism for debasing his art and "selling out." Warhol's assistant in this decade, Ronnie Cutrone (b. 1948), recalled "There were always a number of portraits to do. That was work. But then there were other times when Andy would say 'OK, now what are we going to do for art?"190 Warhol's love of traditional subjects such as still-lifes, mixed with his passion for dramatic overtones like shadows, inspired much of his work in the 1970s. ${ }^{191}$ In 1976, the artist created a remarkable series known as the Skull paintings (figure 15). Although the composition of Skull is similar to Warhol's iconic paintings of the 1960s such as the Campbell's Soup Can paintings (figure 16), the addition of a ground line in this piece points out that the skull is resting on a surface, perhaps a table. Since ground lines are uncharacteristic for Warhol, it seems clear that his intention was to produce a Pop rendition of a classic still-life painting.

Whether depicted in the hand of a contemplative saint or at the foot of a cross, the human skull was a common element of religious painting in Roman Catholic countries before

\footnotetext{
${ }^{189}$ As quoted in John O’Connor and Benjamin Liu, Unseen Warhol (New York: Rizzoli International Publications, Inc.), 63.

${ }^{190}$ Bockris, Warhol: The Biography, 380.

${ }^{191}$ Ronnie Cutrone, "Still Life and Abstraction," in Andy Warhol "Giant” Size, ed. Phaidon (London: Phaidon Press Limited, 2006), 522.
} 
and after the Reformation. Early in the seventeenth-century, artists in the religiously-divided Netherlands developed a new genre known as still-life - secular works in which the transience of human life on earth is symbolically represented. The objects of a traditional still-life often convey allegorically the transience of worldly possessions and the inevitability of death - the vanitas theme. ${ }^{192}$ The concept of transience resonated deeply within Dutch culture, but in the aftermath of Calvinist iconoclasm it could only be conveyed in a symbolic language rather than with the explicitly Catholic iconography of saints or the Crucifixion. In vanitas still-life paintings, artists utilized images of the skull as a subtle yet poignant reminder of the transience of life on earth.

The combination of portraiture and still-life is considered by many art historians to be Dutch artist David Bailly's (1584-1657) most original contribution to seventeenth-century art. ${ }^{193}$ Bailly spent much of his career in the northern city of Leiden, where vanitas still-life painting was particularly prevalent. Historians have noted that the strict Calvinist university in Leiden fostered an intellectual climate conducive to this genre. ${ }^{194}$ In Vanitas Still-life with a Portrait of a Young Painter (1651, figure 17), Bailly depicts himself as a young man sitting at a table on which an elaborate still-life is arranged. By depicting himself surrounded by vanitas elements, including a skull, Bailly was able to demonstrate in a secular manner the transitory nature of earthly life and face his own mortality. The same may be said of Warhol's Self-Portrait with Skull (1978, figure 18).

Warhol developed through Pop art a visual language with which to convey his spirituality in a largely Protestant culture. On the surface, the iconography in Skull and Self-

192 James Hall, Hall's Dictionary of Subjects and Symbols in Art (London: John Murray, 1974), 291.

${ }^{193}$ Walter Liedtke, Dutch Paintings in the Metropolitan Museum of Art (New York: The Metropolitan Museum of Art, 2007), 14.

${ }^{194}$ Scott A. Sullivan, “A Banquet-Piece with Vanitas Implications,” The Bulletin of the Cleveland Museum of Art 61 (October, 1974): 280. 
Portrait with Skull may easily be interpreted as a reminder of the transience of life and the certainty of death. Considering Warhol's relationship with Christian iconography, however, these seemingly secular paintings surpass conventional notions like memento mori and suggest concepts which are unique to the Byzantine Catholic faith. The skull in this context may represent a combination of religious characters: Adam (the first man) and St. John Chrysostom (349-407 CE), the saint for whom the Warhola family church was named.

In Byzantine icons, crucifixion scenes often depict a skull in a tiny cave at the foot of the cross (figure 19). The skull of Adam was buried at Golgotha, or "Place of the Skull," where the crucifixion of Jesus took place. ${ }^{195}$ According to Christian tradition, the skull has two meanings: it identifies the location of the event and it represents the first Adam, dead in sin. Chrysostom suggested that Golgotha's skull was that of Adam and by a century after Chrysostom, the idea of Golgotha as Adam's skull emerged in iconography of the Crucifixion in keeping with St. Paul's teaching that

For since by man came death, by man came also the resurrection of the dead. For as in Adam all die, even so in Christ shall all be made alive...And so it is written, The first man Adam was made a living soul; the last Adam was made a quickening spirit. ${ }^{196}$

Perhaps the strongest reference to "The first man" in Skull is the peculiar shadow in the painting (figure 15). Cutrone began the project by photographing a skull lit with a strong directional light. After the photograph was developed, he was surprised by the unusual appearance of the cast shadow to the left of the skull. Amazingly, the shadow resembled the profile of an infant's face; "a big bald cranium, little nose, and healthy cheeks." According to Cutrone, Warhol's response to the phenomenon was typically unemotional; "Oh, yeah,

\footnotetext{
${ }^{195}$ Hall, Hall's Dictionary of Subjects and Symbols in Art, 81.

${ }^{196}$ I Corinthians 15:21-45 (KJV). See also Martin, Sacred Doorways: A Beginner's Guide to Icons, 143.
} 
that's really wild." ${ }^{\text {197 }}$ Considering his familiarity with biblical stories, the strange phantomlike image in the photograph must have pleased Warhol; the shadow was the perfect accompaniment to the skull as a descendent of the first man, representing all of humanity.

As was customary for Warhol, both Skull and Self-Portrait with Skull were produced in a variety of vivid colors. The red versions may be seen as a reference to the blood of Christ which trickles down directly onto the skull in some icon paintings (figure 20). For Christians, blood on the skull of Adam, the first man, signifies human sin, and the need for the redemption of the entire human race through Christ's atonement on the cross. ${ }^{198}$ When one mourns the loss of a loved one, he or she may be drawn to a certain area of the nave in order to be close to an icon of Christ at Golgotha, and find comfort in its presence. Since icons dwell within the mind of the believer, the image may be called upon outside of the church - in a hospital - at the bedside of a dying patient. It is said that living with this icon aids in the understanding of death, dying and bereavement; it is a reassuring presence that overcomes fear. ${ }^{199}$ Although the image of a skull with allusions to blood may signify the end of life to some, for a Byzantine Catholic like Warhol, it likely suggested spiritual transcendence, perseverance, and hope.

Skull also brings to mind the Byzantine practice of venerating sacred relics. In the Byzantine tradition, kissing the skull of a holy person is believed to be the context for contact with the divine. In some versions of Skull, the central object in the composition is painted in metallic gold, lending it the appearance of a relic that is precious and meant for veneration (figure 21). Warhol was well acquainted with stories of the patron saint of his church, St.

${ }^{197}$ According to Cutrone, the shadow in Skull was "one of those art mistakes that happens when you're working and working and you come across something that you didn't know was there." See O'Connor and Liu, Unseen Warhol, 63.

${ }^{198}$ Martin, Sacred Doorways: A Beginner's Guide to Icons, 143-144.

${ }^{199}$ Ed Horvat, interview with author, December 9, 2009. 
John Chrysostom, the Archbishop of Constantinople. After his death in the fifth-century, the saint's skull was displayed in an elegant silver box in a monastery on Mount Athos, the center of Orthodox Monasticism, on the northeast coast of Greece. Chrysostom's skull was kissed and venerated by the faithful; it was said to have been one of the holiest relics of Mount Athos. The gold version of Skull may be viewed as homage to the Saint who is commonly referred to as "the golden mouthed" for his oratorical skills. ${ }^{200}$ Throughout his life, Warhol held onto the belief that the image can act as a spiritual doorway - a connection between the physical and spiritual worlds.

To locate the spiritual content of his work, it is essential to look beyond Warhol's subject matter and consider his choice of medium. Skull and Self-Portrait with Skull were produced utilizing commercial methods of mechanical reproduction that seemed to preclude any suggestion of gestural expression. In 1978, Warhol unexpectedly abandoned his customary silkscreen technique, which he had employed since 1962, and took up a startlingly unconventional medium.

\section{Chapter XII: Finding the Sacred in the Profane: Oxidation}

When I showed [the Oxidation Paintings] in Paris, the hot lights made them melt again; it's very weird when they drip down. They looked like real drippy paintings; they never stopped dripping because the lights were so hot. Then you can understand why those holy pictures cry all the time - it must have something to do with the material that they were painted on, or something like that.

$$
\text { Andy Warhol }{ }^{201}
$$

In an intriguing series of works titled Oxidation (1978, figure 22), or the "Piss Paintings," as they were originally called, Warhol ventured into pure abstraction. To initiate the project, Warhol and a number of collaborators spread a large canvas primed with copper

\footnotetext{
${ }^{200}$ Carey, "Chrysostom, John, Saint, Patriarch of Constantinople” (accessed March 18, 2008), http://vnweb.hwwilsonweb.com.

201 As quoted in Andy Warhol “Giant” Size, ed. Phaidon (London: Phaidon Press Limited, 2006), 532.
} 
pigment across the studio floor and then, with a nod to Yves Klein (1928-1962) and his Anthropométrie paintings, became "living brushes" as they urinated across the shimmering surface. Over time, as the uric acid and copper sulfate oxidized, mysterious pools and splatters of malachite green and glistening gold foam magically appeared. ${ }^{202}$ Warhol produced several versions in a range of formats, from a Warholian grid of twelve small panels (figure 23) to a single large canvas more than seventeen feet long (figure 22).

As unorthodox as these alchemical experiments must have seemed at the time, they foreshadowed what would become a defining characteristic of contemporary art in the 1980s, when style and medium became merely consequences of the artistic concept. ${ }^{203}$ Though Pop art was the heir to an abstract rather than a figurative tradition, the Oxidation paintings represent a dramatic departure for Warhol; their metallic grounds are the only basis for comparison to his earlier work. Shiny, iridescent surfaces are the foundation of much of Warhol's work, such as the gold leaf drawings of the 1950s (figure 25) and the portraits of Elvis Presley (figure 24) and Marilyn Monroe (figure 12) of the 1960s. When he embarked on the path of abstraction, Warhol lunged into the physical action and performance of painting, thereby revealing the essentially carnal nature of his imagination guided by the religion he practiced throughout his life. ${ }^{204}$

In the 1970 s, many except a few despondent formalists came to the sobering conclusion that the art of painting was at long last dead. ${ }^{205}$ Despite the fact that he coolly dismissed painting as "so old-fashioned" in the 1960s, Warhol admired abstract painting and secretly

\footnotetext{
${ }^{202}$ Bourdon, Warhol, 371.

${ }^{203}$ Ketner, Andy Warhol: The Last Decade, 15.

${ }^{204}$ Ketner, Andy Warhol: The Last Decade, 15.

${ }^{205}$ Eleanor Heartney, Critical Condition: American Culture at the Crossroads (Cambridge: Cambridge University Press, 1997), 32.
} 
believed that abstraction was "real art," according to Cutrone. ${ }^{206}$ The streams of urine in these alchemical experiments are evocative of the rich, flowing colors that surged across the canvases of several painters of the modern era; many achieve a psychological effect similar to that of Helen Frankenthaler's stain paintings, or Morris Louis' poured acrylic works. Associations with Jackson Pollock's drip paintings and his rumored antics are irresistible, such as his custom of urinating on a canvas before delivering it to a client he disliked, or his legendary emission into Peggy Guggenheim’s fireplace. ${ }^{207}$

As much as he liked his work to contain art historical references, Warhol's true gift was his ability to sense changes in popular culture as they happened. In the 1970s, New York was a "Sexed-Up, Doped-Up, Hedonistic Heaven," to quote a 1977 article by author Tom Wolfe (b. 1931). Gay bath houses in Manhattan and backroom bars of the West Village such as The Anvil and The Toilet thrived, providing an outlet for a variety of sexual eccentricities and fetishes. Warhol's Interview editor and colleague Bob Colacello attributes the Oxidation paintings to stories Warhol had heard about The Toilet, possibly reinforced by events at the opening of his 1977 Hammer \& Sickle exhibit in Paris. Colacello recalls the artist spending much of the evening in another room, oblivious to the Chablis-guzzling, leather-clad punks urinating on the gallery floor. When Warhol was alerted about the situation, he laughed softly and simply said, "Pee is getting big, Bob."208

Despite the fact that much of the literature concerning Warhol's sexuality portrays him as asexual, some see overtly gay overtones in his "hands free" approach to painting in Oxidation. ${ }^{209}$ Queer theorists Simon Watney and Jennifer Doyle have noted the persistence

\footnotetext{
${ }^{206}$ Ketner, Andy Warhol: The Last Decade, 15. See also Hickey et al, Andy Warhol “Giant” Size, 522.

${ }^{207}$ Colacello, Holy Terror: Andy Warhol Close Up, 342. See also Bockris, Warhol: The Biography, 419.

${ }^{208}$ Colacello, Holy Terror: Andy Warhol Close Up, 340-341.

${ }^{209}$ Ketner, Andy Warhol: The Last Decade, 15.
} 
of homosexual references throughout the artist's work - in his films, as well as in the gracefully rendered nude boys in early drawings (figure 25). Although Warhol's public persona appeared as homosexual - his behavior was sometimes described as "swish" - he maintained a certain ambiguity about his sexuality. The artist expected his associates to disclose intimate details about their relationships, yet he left the particulars of his romantic affairs unclear. ${ }^{210}$ Perhaps Warhol's reticence was due to his Catholic upbringing. Although he discreetly attended church several times a week at St. Vincent Ferrer Roman Rite Catholic Church in New York as an adult, he did not go to confession or take communion after the age of twenty-one. The parish priest at St. Vincent Ferrer, perhaps motivated by events surrounding the 1969 Stonewall Riots in Greenwich Village, preached regularly against homosexuality, which may explain Warhol's unwillingness to go to confession and participate in the sacraments. $^{211}$

If Catholic dogma scorned Warhol's homosexuality, it also provided him with images of homoeroticism and male desire; Christianity's central image is a nearly nude male whom people of both genders are urged to love. ${ }^{212}$ Many Catholic artists have observed that Catholicism's imagery and rituals create a climate that is somewhat receptive to homoeroticism and homosexuality. In some of the most venerated masterpieces of religious art, the male body has been idealized and at times eroticized. Both Michelangelo's masculine representations of women and Leonardo's effeminate saints and angels may be seen as a reflection of the artists' sexual preferences. Saint Sebastian has emerged as a gay

\footnotetext{
${ }^{210}$ Michael Lobel, “Warhol's Closet,” Art Journal 55 (Winter, 1996): 44.

${ }^{211}$ Eleanor Heartney, Postmodern Heretics: The Catholic Imagination in Contemporary Art (New York: Midmarch Arts Press, 2004), 38.

${ }^{212}$ Heartney, Postmodern Heretics: The Catholic Imagination in Contemporary Art, 38.
} 
icon for many contemporary artists, due in large part to his sinuously erotic portrayal by artists such as Mantegna, Botticelli and Bernini. ${ }^{213}$

In 1957, Warhol self-published A Gold Book and exhibited its illustrations along with other drawings at the Bodley Gallery in New York. The artist's homosexuality was fairly explicit in these idealized portraits of attractive young men. The drawing Golden Boy (figure 25), which dates from this period, is a full-length portrait of a nearly nude male in threequarter view. $^{214}$ The pictorial space in traditional iconography makes the figure appear as if it were floating on a shallow stage (figure 26). The shallow, forward-thrusting pictorial space encourages the viewer to relate to the subject personally. ${ }^{215}$ Similarly, the pictorial space in Golden Boy pushes the object of Warhol's desire before the viewer.

In the late silkscreen series Sex Parts (1978, figure 27), Warhol depicts enlarged views of male sexual organs and explicit homosexual acts. These little-known works were created during the same year as Oxidation, as were artist Robert Mapplethorpe's (1946-1989) photographs for his notorious $X$ Portfolio. ${ }^{216}$ Some commentators argue that Mapplethorpe's work speaks of a personal struggle between his homosexual identity and his Catholic upbringing; the same might be said of Warhol's art. ${ }^{217}$ In Stanislaw Mucha's 2001 documentary Absolut Warhola, revealing interviews with Warhol's relatives in Mikova expose their struggles with crippling poverty, strong religious faith, and resolute homophobia. Warhol was not a "you-know-what," they claimed; in fact, "no homosexual

\footnotetext{
${ }^{213}$ Heartney, Postmodern Heretics: The Catholic Imagination in Contemporary Art, 65-75.

${ }^{214}$ Bourdon, Warhol, 47-51.

${ }^{215}$ Martin, Sacred Doorways: A Beginner's Guide to Icons, 134.

${ }^{216}$ Artist Robert Mapplethorpe's X Portfolio featured explicit images of sadomasochistic homosexual acts. The photographs, which were part of the 1988 traveling retrospective "The Perfect Moment," sparked a firestorm of controversy that set off a congressional battle to eliminate the NEA for contributing money to the exhibition. See Heartney, Postmodern Heretics: The Catholic Imagination in Contemporary Art, 82.

${ }^{217}$ Heartney, Postmodern Heretics: The Catholic Imagination in Contemporary Art, 80-81.
} 
ever came from Mikova., ${ }^{218}$ Not surprisingly, Warhol maintained an ambiguity about his sexuality in public; the artist once famously quipped: "fantasy love is much better than real love ... the most exciting attractions are between two people who never meet." ${ }^{219}$

Contradicting his supposed lack of interest in carnal activity are other published statements in which Warhol professes his love of pornography: "Personally, I loved porno and bought lots of it all the time - the real dirty, exciting stuff."220 Art critic Eleanor Heartney observes that because pornography sheds light on those dark corners of human experience that most would rather keep hidden, it can provide artists with the opportunity to explore the limits of the possible. Pornography's outsider status offers marginalized groups a forum through which to challenge the prevailing norms of a system from which they are excluded. In the pre-AIDS era of the 1970s, backroom establishments such as The Toilet provided male homosexuals a venue for expressing their so-called "deviant" sexuality in a largely heterosexual culture. ${ }^{221}$

The act of urinating on canvas may easily be seen as an outlet for forbidden sexual impulses and desires, but as art historian David Bourdon noted in his 1989 biography of Warhol, with Oxidation, the artist was "far more interested in the alchemical implications, converting bodily fluids into something aesthetic and valuable.”222 Warhol's artistic experiments with urine went largely unnoticed in the 1970s, unlike those of photographer Andres Serrano in the late 1980s. In 1989, the photographer fueled a firestorm of controversy with Piss Christ (figure 28), a photograph immortalized in the media as "the

\footnotetext{
${ }^{218}$ Scherman and Dalton, Pop: The Genius of Andy Warhol, 2.

${ }^{219}$ Heartney, Postmodern Heretics: The Catholic Imagination in Contemporary Art, 36-37.

${ }^{220}$ Heartney, Postmodern Heretics: The Catholic Imagination in Contemporary Art, 36-37.

${ }^{221}$ Heartney, Critical Condition: American Culture at the Crossroads, 116.

${ }^{222}$ Bourdon, Warhol, 371.
} 
crucifix dipped in urine." Piss Christ was interpreted by its critics to mean "piss on Christ," but Serrano, a Roman Catholic, intended it to be a celebration of the human body. ${ }^{223}$

In Serrano's photograph, a yellow-orange glow surrounds an inexpensive wood and plastic crucifix; its radiance derives from light shining through urine. Catholicism's emphasis on transformation, transfiguration and transubstantiation inspire works such as this. Just as the substances of bread and wine become the body and blood of Christ in the Catholic Mass, so Serrano takes material normally considered vile, and consecrates it into a work of art with an almost sacramental quality. The artist once told an interviewer: "I've completely aestheticized this very base material and in my pictures, piss is not something repugnant, it's something very beautiful, it's a beautiful glowing light." In another interview, Serrano said “you can't have the sacred without the profane. What is wrong is to make something that isn't beautiful.,"224

The Oxidation paintings may be viewed in a similar light. With their provocative fusion of the sacred and the profane, they are beautiful - luminously otherworldly and at the same time, this worldly. Although they bear little resemblance to his Pop icons and society portraits, these mysterious images are imbued with a similar physical presence; they recall Warhol's early aspirations for painting: "The situation, physical ideas. Physical presence - I feel this is the comment." 225 This unusually candid remark from Warhol is enlightening, especially when one considers his Byzantine Catholic upbringing and his regular attendance at Mass. $^{226}$

\footnotetext{
${ }^{223}$ Heartney, Postmodern Heretics: The Catholic Imagination in Contemporary Art, 112-117.

${ }^{224}$ Heartney, Postmodern Heretics: The Catholic Imagination in Contemporary Art, 112-117.

${ }^{225}$ Ketner, Andy Warhol: The Last Decade, 71.

${ }^{226}$ Peter Kattenberg, Andy Warhol, Priest: The Last Supper Comes in Small, Medium and Large (Boston:
} Brill, 2001), 3. 
The Mass, or the Divine Liturgy, is the essential component of worship in Byzantine Catholicism (see page 20). ${ }^{227}$ An understanding of the relation of spirit and matter in the Eucharist may be compared to the mystery of art. According to art historian Peter Kattenberg, whenever a work of art appears to be both spiritual and material, it plays the same role as the Eucharist bread does. In the Eucharistic celebration, what is presented to the attendant is not what it seems to be, but to a faithful Catholic, there is no question that a transformation did take place. ${ }^{228}$ Belief in the true presence of Christ in the Eucharist in the East differs from the West; "matter," "form," "substance," and "accidents" are rarely mentioned, and the word "transubstantiation" is only used in dialogue with the West. For Byzantine Catholics, the wonder of the Eucharist comes about by the power of the Holy Spirit, and the "how" of the real presence is not important. ${ }^{229}$

Similarly, there is often a notion of the supernatural associated with art, and an artist is thought to have the power to make an object seem both material and spiritual like the elements of the Eucharist. ${ }^{230}$ In the 1960 s, a time when people were threatened by the trend towards de-personalization in the arts and the implications of a technological society, Warhol metaphorically disappeared into a "machine," miraculously transforming the banal and commonplace into high art. ${ }^{231}$ After Oxidation and until his death in 1987, Warhol continued to experiment with abstraction in monumental works such as Shadows (1978, figure 29),

${ }^{227}$ Lawrence Cross, Eastern Christianity: The Byzantine Tradition (Philadelphia: E.J. Dwyer, 1991), 58.

${ }^{228}$ Kattenberg, Andy Warhol, Priest: The Last Supper Comes in Small, Medium and Large, 4-6.

${ }^{229}$ Lawrence Cross, Eastern Christianity: The Byzantine Tradition, 58.

${ }^{230}$ Kattenberg, Andy Warhol, Priest: The Last Supper Comes in Small, Medium and Large, 46.

${ }^{231}$ Kattenberg, Andy Warhol, Priest: The Last Supper Comes in Small, Medium and Large, 14. See also Lippard, Pop Art, 10. 
Yarn (1983), and Rorschach (1984). The artist continually sought subjects that not only functioned as formal abstractions, but were also replete with meaning. ${ }^{232}$

In the expressionistic The Last Supper (Be Somebody with a Body) (1985, figure 30), the slogan from a body building advertisement overlaps an image of a body builder who resembles a young Warhol. Surrounded by a halo-like aura, the figure and text are superimposed by a line drawing of Christ depicting the moment from the Last Supper when he says "This is my body," thereby transforming the bread of the Eucharist into his flesh. The halo visually suggests that the body builder has been transformed and, acknowledging Warhol's background, "be somebody with a body" becomes an expression of his carnal consciousness - a celebration of the physical impulses that were kept hidden because they were in conflict with his cultural and religious identity. ${ }^{233}$

Early Church fathers such as John of Damascus felt no need to divide history and art into secular and sacred as happened after the Protestant Reformation. Since God is the creator of all, there is no sharp distinction between the sacred and the profane, between the physical and the metaphysical. "Let us search the wisdom of the profane," John of Damascus wrote. "Perhaps we can find something useful from there, and we may profit by finding therein something edifying for our souls. ${ }^{234}$ According to Kattenberg, the significance of Warhol's art centers on the mystery of transformation, and his ability to find the sacred in the profane. ${ }^{235}$ By utilizing a bodily fluid normally perceived as vile and

${ }^{232}$ Ketner, Andy Warhol: The Last Decade, 27.

${ }^{233}$ In her analysis of Warhol's The Last Supper (Be Somebody with a Body), art critic Eleanor Heartney sees the combination of Christ's outstretched hand and haloed body builder as "an advertisement for our Incarnational consciousness." Heartney, Postmodern Heretics: The Catholic Imagination in Contemporary Art, 38.

\footnotetext{
${ }^{234}$ Limouris, Icons: Windows on Eternity, 115.

${ }^{235}$ Kattenberg, Andy Warhol, Priest: The Last Supper Comes in Small, Medium and Large, 4.
} 
participating in what might be viewed as an act of sexual depravity, Warhol explored the profane and created a work of art imbued with a sacred, transcendental quality.

Although Warhol continually experimented with abstraction, he did not fully embrace it until late in his career. In the 1960s, the Pop artist defied Abstract Expressionism's painterly, non-objective explorations of the subconscious with mechanically reproduced, purely objective machinations of consumer society. No matter how humble the can of soup or glamorous the celebrity, an undercurrent of death often loomed beneath the surface of Warhol's serially-repeated images. When his dramatic installation of Shadows (1978, figure 29) was first exhibited in New York's Heiner Friedrich Gallery in January of 1979, audiences were presented with the same associations, but in an unexpectedly abstract manner. ${ }^{236}$ In Shadows, Warhol was able to further his exploration of transience by utilizing a familiar strategy: repetition.

\section{Chapter XIII: Shadows: Imitate, Replicate, Repeat}

Isn't life a series of images that change as they repeat themselves?

Andy Warhol ${ }^{237}$

Throughout his life, Warhol was so haunted by death that he found it difficult to fall asleep before dawn out of fear that he would die in the night. ${ }^{238}$ After Valerie Solanas shot him in 1968, the artist was pronounced clinically dead on the operating table and resuscitated one minute and a half later. ${ }^{239}$ Years before that traumatic experience, the artist sensed that he was "more half-there than all-there" and after the shooting "knew" that he was "watching

\footnotetext{
${ }^{236}$ Warhol's Shadows series is currently owned by the Dia Foundation and housed in the Dia Beacon Riggio Galleries in Duchess County, New York. See Lynne Cooke, "Andy Warhol: Shadows" (accessed June 10, 2008), http://www.diacenter.org/exhibs/warhol/shadows/essay.html.

${ }^{237}$ As quoted in Victor I. Stoichita, A Short History of the Shadow (London: Reaktion Books Ltd., 1997), 207.

${ }^{238}$ Heartney, Postmodern Heretics: The Catholic Imagination in Contemporary Art, 35.

${ }^{239}$ Bockris, Warhol: The Biography, 302-303.
} 
his life on television."240 Ten years after his brush with death, Warhol found a new approach in his art to exorcise his demons. Although Shadows may seem to be an unusual subject for Warhol, shadows are an everyday phenomenon and, in that sense, they align with the familiar, ordinary subjects of Pop art. ${ }^{241}$ Cutrone recalls that the artist was thrilled at his suggestion to paint shadows "because shadows were not only abstract but also abstractions of something figurative - reflections of something real and therefore conceptual by nature."242

The project began with Cutrone photographing shadows produced by cardboard props expressly devised to create abstract forms. The images were silkscreened onto 102 canvases, each measuring $76 \times 52$ in. $^{243}$ Shadows consists of two compositional formats: one is often referred to as "the peak," which always appears as a positive, in black on a colored ground, and the other is "the cap," which always appears as a negative with a black background. On the left half of each "peak" canvas is a tall, jagged tipped form resting on a diagonal base that covers the bottom third of the canvas. On the left side of each "cap" is a smaller, pointed, cone-shaped form floating above a diagonal bar across the ground that covers the bottom third of the canvas. ${ }^{244}$ Two of the canvases have metallic silver grounds and are silkscreened in turquoise. The remaining one hundred canvases are painted in a range of hues, some bright and acidic, others deep and somber; all are silkscreened in black. ${ }^{245}$ Most of the

\footnotetext{
${ }^{240}$ As quoted in Warhol's book Philosophy. See Hal Foster, "Death in America," October (Winter,
} 1996): 58.

${ }^{241}$ Patrick S. Smith, Andy Warhol's Art and Films (Ann Arbor: UMI Research Press, 1981), 201.

${ }^{242}$ Cutrone, "Still Life and Abstraction," in Andy Warhol "Giant" Size, ed. Phaidon (London: Phaidon Press Limited, 2006), 522.

${ }^{243}$ There are many different accounts of the quantity and arrangement of canvases in the Shadows exhibitions. See Cooke, “Andy Warhol: Shadows” (accessed June 10, 2008), http://www.diacenter.org/exhibs/warhol/shadows/essay.html.

${ }^{244}$ Richard Kalina, “Andy Warhol at the Dia Center,” Art in America 88 (February 1, 2000): 129.

${ }^{245}$ Cooke, “Andy Warhol: Shadows” (accessed June 10, 2008), http://www.diacenter.org/exhibs/warhol/shadows/essay.html. 
colored surfaces are flat and matte in texture, while a few feature expressively broad, sweeping brushstrokes with thick impasto. ${ }^{246}$

Shadows embodies Warhol's innovative and often provocative approach to installation. ${ }^{247}$ The artist took great care in arranging the plethora of canvases, which were installed in both the main room and the back room of the Heiner Friedrich Gallery. The paintings were pressed together and presented as a singular, continuous painting in a wraparound installation. ${ }^{248}$ Since there are no breaks, the viewer is able to focus on the dark landscape of paintings without the reminder of white gallery walls. Shadows engulfs the viewer in a seemingly endless panorama of repeated images that are as mentally engaging as watching a film in a dark movie theater. In a review which appeared in the April 1979 issue of Artforum after the first Shadows exhibition, art critic Carrie Richey observed:

[T] he installation suggests these images be read sequentially, like movie frames. Very cinematic. Examining the canvases for a possible narrative, I realize that, reading clockwise, the acid colors of the first sixty are replaced by silvers and black and white in the last half dozen. A fade-out? ${ }^{249}$

As an installation, Shadows is as dramatic and film-like as Warhol's 1963 Elvis 11 Times (figure 24). The connotation of death is palpable in this single, monumental painting featuring eleven identical photograph screens of a gun-slinging Elvis Presley. As the viewer stands before the nearly thirty-seven foot long canvas, the composition suggests that there are more menacing figures beyond the frame; the implied repetition, exterior to the painting,

${ }^{246}$ Kalina, “Andy Warhol at the Dia Center,” 129.

${ }^{247}$ Unknown author, "Painter Hangs His Own Paintings,” New York Magazine 5 (February, 1979): n.p.

${ }^{248}$ Excerpt from Bourdon's description of the 1979 installation of Shadows at the Heiner Friedrich Gallery. See Bourdon, Warhol, 372.

${ }^{249}$ From an Artforum review of the original exhibition of Shadows in 1979, in which art critic Carrie Richey lists sixty-six canvases. See Stoichita, A Short History of the Shadow, 205. 
takes place in the imagination. ${ }^{250}$ In Shadows, there is no implication that there are images beyond the picture plane as the eye endlessly circles around the room. Like many of Warhol's films, the ceaseless repetition keeps the viewer absorbed in the image and the internal associations that it brings to mind. The somber and majestic processional of the Mass inspired Warhol and many other Catholic artists to create this kind of imagery.

Several Catholic writers of the twentieth-century, such as Frank O’Hara (1926-1966), were fascinated with the film industry. In much of his work, O'Hara imagines the cinematic immortality of the silver screen as a secular equivalent to the eternity of Christian Heaven. In his poem Ave Maria (1964), film mimics the atmosphere of the Catholic liturgy: "the soul that grows in darkness" is "embossed by silvery images" from the movies. ${ }^{251}$ Perhaps the reflective silver walls of Warhol's Factory may be viewed in a similar light. ${ }^{252}$ The artist compared the silver-lined walls of the Factory to the "silver screen" of the cinema but, considering Warhol's religious upbringing, they may also have been an expression of his desire to surround himself with one immense icon that would simulate the heavenly ambiance of his family church in Pittsburgh.

Warhol had been an avid movie-goer in Pittsburgh and, as an adult he spent countless hours watching films in New York cinemas. According to historian Paul Gilles, the power of the Catholic liturgy, like the power of cinema, resides in its ceaseless aspiration, which is never fully resolved, to transform the irony of difference between perception and reality. ${ }^{253}$ There is also an irony of difference in Warhol's work; although his silkscreened paintings are

${ }^{250}$ Ganis, “Andy Warhol's Iconophilia,” In Visible Culture / An Electronic Journal for Visual Studies (2000): 1-14. (accessed June 24, 2006), http://www.rochester.edu/in_visible_culture/issue3/ganis.htm.

${ }^{251}$ Gilles, American Catholic Arts and Fictions: Culture, Ideology, Aesthetics, 260-275.

${ }^{252}$ When hairdresser and lighting technician Billy Linich (b. 1940) covered the walls of a friend's apartment with silver paint and tinfoil, it made a big impression on Warhol. In 1964, Warhol asked Linich to decorate his studio, "The Factory," the same way. See Bockris, Warhol: The Biography, 191.

${ }^{253}$ Gilles, American Catholic Arts and Fictions: Culture, Ideology, Aesthetics, 260-275. 
perceived as anti-gestural, impersonal, mechanical reproductions, they are in fact a set of variations, as Warhol acknowledged when he described the process as the "same image but slightly different each time." ${ }^{254}$ The duplication of the image is not mechanical; it only looks mechanical. The clogging of Warhol's silkscreen, the off-register impressions, the faded imprints, the image disappearing as the gummed screen blackens the image are his version of expressionistic drips, jabs, and swirls. ${ }^{255}$

The use of the silkscreen process would seem to preclude the spontaneity and risk of Abstract Expressionism; ironically, Shadows is evocative of color field painter Barnett Newman's (1905-1970) Stations of the Cross (1966, figure 31), which was first installed in New York's Guggenheim Museum in $1966 .{ }^{256}$ The Stations of the Cross: Lema Sabachthani (“My God, my God, why hast thou forsaken me?") is a series of fourteen abstract paintings which, as the title suggests, Newman associated with the intensity of Christ's passion. ${ }^{257}$ During the season of Lent, some Roman Catholics meditate before a cycle of fourteen compositions known as The Stations of the Cross, each one depicting a different event that occurred during the final hours of the life of Christ. The paintings represent the various locations that medieval believers visited during their pilgrimages to Jerusalem. The son of Jewish immigrants from Poland, Newman titled his series The Stations of the Cross not in reference to their iconography, but to their psychological effect. Believing that "the visual experience of the painting [should be] a single experience," Newman intended his Stations to

${ }^{254}$ Dalton, "Matinee Idols," in Andy Warhol "Giant" Size, ed. Phaidon (London: Phaidon Press Limited, 2006), 174.

${ }^{255}$ Dalton, "Matinee Idols," in Andy Warhol "Giant” Size, ed. Phaidon (London: Phaidon Press Limited, 2006), 174.

${ }^{256}$ Art historian Jane Daggett Dillenberger argues that Warhol's Shadows series "belong[s] in the company of Newman's Stations of the Cross." See Dillenberger, The Religious Art of Andy Warhol, 63.

${ }^{257}$ A biblical account of Christ's passion reads, “And about the ninth hour Jesus cried with a loud voice, saying, Eli, Eli, lama sabachthani? that is to say, My God, my God, why hast thou forsaken me?" See Matthew 27:46 (KJV). 
be exhibited as one painting. ${ }^{258}$ As an artist working in New York during that time, Warhol was surely aware of this ground-breaking exhibit by one of the most formidable figures of Abstract Expressionism. More importantly, the artist was also surrounded by The Stations of the Cross paintings on the walls of the nave of his neighborhood church in New York, St. Vincent Ferrer. Although it is not a Byzantine Catholic tradition, the gilded surfaces of The Stations of the Cross paintings in St. Vincent Ferrer resemble the Byzantine icons with which Warhol grew up. ${ }^{259}$

As each "station" is passed in Newman's installation, spectators attend to the unfolding of differences through repetition as if they are viewing frames in a reel of film. ${ }^{260}$ Most of the canvases feature a variety of black and white lines; some vertical, some horizontal. White paint takes the place of black in some, while in others the color contrast of black and white is replaced by the tonal contrast of white and raw canvas. Some of the canvases contain smeared black paint, repetitive dabs, and splatters along each line, while others are crisply painted. The surface of the Thirteenth Station is mostly black, while the Fourteenth Station is free of all brush marks and value contrasts (figure 32). As the viewer approaches this surprisingly vacant station, the previous one is recalled, activating memories and evoking the feelings of emptiness and loss which resonate in Christ's expression of despair: "My God, my God, why hast thou forsaken me?"261

The emotional effect of Shadows (figure 29) is strikingly similar to that of Newman's The Stations of the Cross. The dark, indistinguishable scene directs the viewer along the perimeter of the gallery, and as each painting is passed the abrupt changes in color and form

${ }^{258}$ Ann Temkin, ed., Barnett Newman (Philadelphia: Philadelphia Museum of Art, 2002), 78.

${ }^{259}$ In 2011, this author attended Mass at Warhol's neighborhood church in New York, St. Vincent Ferrer. Several of The Stations of the Cross paintings displayed there stylistically resemble Byzantine icons.

${ }^{260}$ Melissa Ho, ed., Reconsidering Barnett Newman (New Haven, London: Yale University Press, 2005), 48.

${ }^{261}$ Ho, ed., Reconsidering Barnett Newman, 54-56. 
stir intense feelings that alternate between presence and loss, joy and grief. Like Newman, Warhol presents a continuous cycle of repetitive abstract images that fluctuate between positive and negative, bright and somber, flat and expressive. The two silver and turquoise canvases in Shadows, like Newman's Fourteenth Station, are startlingly different from the otherwise overwhelmingly black setting. They are two intermittent flashes of light, like the bright flicker of film projected in a dark movie theatre. Warhol never tired of exploring the possibilities of repetition. With Shadows, the artist continued what he began fifteen years earlier with Elvis 11 Times; dealing with the specter of death but in a non-objective, abstract manner.

During the same year he created Elvis 11 Times, Warhol and then-assistant Nathan Gluck produced a series of works based on an image of a modern instrument of death: a photograph of an empty electric chair. In 1963, two executions were carried out in New York's Sing Sing state penitentiary, where the photograph was probably taken. ${ }^{262}$ In Double Silver Disaster (1963, figure 33), Warhol stacked a double image of an electric chair on the left side of the canvas, perhaps in reference to the two highly publicized executions. The Catholic Church's position on the death penalty has always been linked with the respect for human life. All human beings, according to Scripture, are created "in the image and likeness of God," and redeemed by Jesus Christ who lived and died "that they may have life."263 Perhaps commenting on the growing practice of state executions in New York, Warhol transformed the electric chair into a modern day cross. ${ }^{264}$ The Roman Empire - the government that found Jesus of Nazareth guilty of sedition and treason, for which he was executed - tortured to death those criminals convicted of the most heinous crimes by hanging

${ }^{262}$ Dillenberger, The Religious Art of Andy Warhol, 70.

${ }^{263}$ Cardinal Adam Maida, "Life and Dignity of the Human Person" (accessed April 8, 2008), http://www.micatholicconference.org.

${ }^{264}$ Dillenberger, The Religious Art of Andy Warhol, 71. 
them on a cross until they died from gradual asphyxiation, usually several days later. It was a particularly horrific way to die. ${ }^{265}$ The cross on which Christ was crucified is commonly seen in religious art as a symbol of salvation. Although the electric chair in Double Silver Disaster evokes the barbarism of capital punishment, it may also signify redemption.

The canvas of Double Silver Disaster was painted with the same allover hue, and an image was silkscreened in black ink on only one side, leaving the other side a plain monochrome. "Wouldn't it be a good idea to add a blank panel?" he once asked friends. "It would make the painting twice as big and twice as expensive. ${ }^{266}$ As is so often the case with Warhol, formal choices such as these were not made as carelessly as he would have liked everyone to believe. The emotional impact of this blank panel is similar to that of Newman's Fourteenth Station (figure 32); as the viewer contemplates the empty electric chair on the left, the void in the right panel evokes the feelings of emptiness and loss which resonate in Christ's words: "My God, my God, why hast thou forsaken me?" Warhol's obsession with death seems to inform paintings such as Double Silver Disaster; like The Stations of the Cross, these evocative paintings invite the viewer to reflect on the transience of life and the hope of redemption.

A sign to the right of the electric chair in Double Silver Disaster admonishes "silence" (figure 33). The silent veneration of holy icons lies at the heart of Warhol's voyeuristic tendencies; his love of "looking" was clearly exhibited when he became a filmmaker during the summer of 1963. His early silent films Eat (1963), Sleep (1963), and Haircut (1963) were characterized as "underground," a term ripe with negative connotations of seediness and corruption. The concept behind these alternative films is what made them so provocative. Instructing his performers to move as little and slowly as possible, Warhol

\footnotetext{
${ }^{265}$ Josette M. Bassler, "Cross," in Harper Collins Bible Dictionary, ed. Paul J. Achtemeier (New York: HarperCollins Press, 1996), 211-212.

${ }^{266}$ See Bourdon, Warhol, 158.
} 
filmed friends and associates engaging in activities as mundane as eating a mushroom, getting a haircut, and sleeping for, in some instances, several hours at a time. Filmed at a leisurely twenty-four frames per second, Warhol's essentially "motionless" films evoke the stillness of Byzantine icons. ${ }^{267}$ Throughout his life, Warhol experienced icons as sacred images that posses an innate quality of stillness that summon the viewer to quiet contemplation. ${ }^{268}$ It is said that when one is before an icon, stillness is tangibly felt; the same may be said of Warhol's films, and transcendental paintings such as Shadows and Double

\section{Silver Disaster.}

In the final years of his life, the content of Warhol's work expanded to include subjects which were explicitly religious. In 1985, Warhol turned to a Renaissance masterpiece for his first overtly religious painting: Raphael's Sistine Madonna (1513-1514, figure 34). Although Raphael I-6.99 (1985, figure 35) and other late paintings have been carelessly dismissed by critics as "failures of some sort," they provide undeniable proof that Warhol's work was inspired by one of the earliest form of Christian art - the Byzantine icon. ${ }^{269}$

\section{Chapter XIV: For What it's Worth: Warhol's Madonna}

Ijust think people should be doing two things at one time, you know...I think the people who do news should also be having breakfast or getting their nails done or something.

Andy Warhol ${ }^{270}$

${ }^{267}$ According to art historian David Bourdon, Warhol instructed his performers to move as little and as slowly as possible, and then filmed his scenes at sound speed (twenty-four frames per second). "When he later projected the films at silent speed (sixteen frames per second), he turned the initially sluggish movement into an even more trancelike slow motion." See Bourdon, Warhol, 169.

${ }^{268}$ Martin, Sacred Doorways: A Beginner's Guide to Icons, 217.

${ }^{269}$ In a book published in 1992, art historian Arthur C. Danto examines Warhol's Raphael I-6.99 and The Last Supper (Dove), and concludes "Perhaps these last paintings are failures of some sort." See Arthur C. Danto, Beyond the Brillo Box: The Visual Arts in Post-Historical Perspective (New York: Farrah, Straus, Giroux, 1992), 144.

${ }^{270}$ As quoted in Andy Warhol “Giant” Size, ed. Phaidon (London: Phaidon Press Limited, 2006), 448. 
In Raphael I-6.99 Warhol adapted, varied, and transformed Raphael's Sistine Madonna. Warhol's composition includes not one but two Mary figures and two Christ figures in the center of an uninflected white canvas. Often overlooked beneath the left foot of Mary is a rosary, a strand of prayer beads often used by Catholics for the practice of Marian devotion. The only colors in the painting are the blue of the Virgin's robe, the pink flesh of the Christ Child, and the large red and yellow price tag which is superimposed over the sacred image. Warhol made several omissions to Raphael's composition; absent are the fluffy clouds, the vaporous cherubim, the curtain rod, the halo over the pope's head, and the crown and ledge on which two putti are leaning at the bottom of the canvas. The compositional clarity of Raphael I demonstrates how Warhol used the visual language of his time to reflect the postmodern age in which he lived, and the religious iconography that was embedded in his psyche.

Artists of the Byzantine era created numerous iconic types of Madonna and Child, such as the Virgin Hodegitria, which is still repeated (see page 14). Although Byzantine icons must resemble their prototype, they must also be abstract in order to emphasize Mary's spirituality over her humanity. ${ }^{271}$ Artists of the Italian Renaissance, particularly Raphael, preserved some of the earlier poses, but created highly illusionistic renderings of the Virgin which mirror that era's interest in humanism and idealized notions of feminine beauty and grace. Given Warhol's background, it is not surprising that his characteristically nonillusionistic, abstract portrayal of the Madonna resonates more with Byzantine ideology than it does with that of the Renaissance.

Warhol was well acquainted with iconic images of the Virgin; she is one of the most frequently represented figures in Byzantine art. Mary is represented by several iconographic types with specific differences, but she is always depicted as the Mother of God; beautiful

${ }^{271}$ Kenna, "Icons in Theory and Practice: An Orthodox Christian Example," 345-349. 
and sacred, the definitive model of womanhood. ${ }^{272}$ In the nineteenth-century, the Virgin Mary in Raphael's allegory of the pope's entry into Paradise became a popular representation of ideal motherhood, and Catholics began purchasing reproductions of Raphael's numerous Mother and Child paintings to display in their homes. ${ }^{273}$ By the twentieth-century, an extraordinary explosion in the reproduction of products occurred, which included works of art. Many cultural theorists, from Walter Benjamin (1892-1940) to Jean Baudrillard (19292007) have seen a diminution in the authority of originality. Benjamin argued that the "aura" of the original work of art is lost with the proliferation of mechanical reproduction. Similarly, Baudrillard proclaimed that the very opposition between original and copy has been lost in an age of simulacra, or repetitions without originals. ${ }^{274}$ Art historian Jane Daggett Dillenberger questioned whether the price tag in Raphael I is a jolting reminder of the commercial marketing world that has reproduced Raphael's religious masterpiece in cheapened and distorted copies, making it "ubiquitous and finally boring." 275

Raphael's Sistine Madonna has been mass-produced and duplicated over the years until it has become a cliché; its aura has been lost, and its religious meaning has diminished. Though some have viewed Raphael's painting in person, the Sistine Madonna is largely known from postcards, calendars, and posters - mechanically and digitally-reproduced sources. Rather than title his painting of the Virgin Sistine Madonna I, Warhol refers to the artist - and a price - in the title Raphael I-6.99. This gesture is significant; it is a reminder of the stark reality of capitalist culture. Raphael I reminds the viewer that art is a commodity,

${ }^{272}$ Cormak, Icons, 63-105.

${ }^{273}$ Frederick Hartt and David G. Wilkins, History of Italian Renaissance Art (Upper Saddle River, New Jersey: Prentice Hall, 2007), 530. See also Colleen McDannell, Material Christianity: Religion and Popular Culture in America (New Haven: Yale University Press, 1998), 62.

${ }^{274}$ Steven Connor, Postmodern Culture: An Introduction to Theories of the Contemporary (Oxford: Blackwell Publishers, 1989), 151.

${ }^{275}$ Dillenberger, The Religious Art of Andy Warhol, 56. 
and there are many more repeated images that exist beyond the picture frame. Throughout his mechanically-duplicated and appropriated imagery, Warhol reminds his audience that in the postmodern era, there can no longer be one unique work of art.

Before and after iconographers had the technology to mechanically reproduce their work, icon paintings were duplicated by hand, and the copies were venerated as if they were originals. Considering his relationship with Byzantine icons, is it any wonder that Warhol did not feel the need to have contact with the original subject of his work? The basis of Raphael I is not the original which hangs in The Old Masters Picture Gallery in Dresden, but rather an appropriated illustration from a late-nineteenth century encyclopedia of art (figure 36). Warhol projected the drawing onto a massive thirteen-foot high white canvas, and traced over it in black acrylic. In contrast to Raphael's illusions of relief, perspective, and spatial and psychological depth, the smooth white surface of Raphael I resembles that of newspaper advertisements - illustrative and flat. Cultural critic Fredric Jameson (b. 1934) uses Warhol's work to argue that there is a loss of "depth" within postmodernity: ${ }^{276}$

$[\mathrm{I}] \mathrm{t}$ is as though the external and coloured surface of things - debased and contaminated in advance by their assimilation to glossy advertising images - has been stripped away to reveal the deathly black and white substratum of the photographic negative which subtends them. Although this death of the world of appearance becomes thematized in certain of Warhol's pieces . . . this is not, I think, a matter of content any longer but of some more fundamental mutation both in the object world itself - now become a set of texts or simulacra - and in the disposition of the subject. ${ }^{277}$

The result of Warhol's distant postmodernist stance from Raphael's original is a contemporary Virgin Mary that resembles a mass-produced mannequin for a department

${ }^{276}$ Fredric Jameson, Postmodernism, Or, The Cultural Logic of Late Capitalism (Durham: Duke University Press, 1991), 9. See also Anders Stephanson, "Regarding Postmodernism - A Converstion with Fredric Jameson," in Universal Abandon?: The Politics of Postmodernism, ed. Andrew Ross (Minneapolis: University of Minnesota Press, 1998), 4.

${ }^{277}$ Fredric Jameson, “The Deconstruction of Expression," in Art in Theory, eds. Charles Harrison and Paul Wood (Oxford: Blackwell Publishing, 2003), 1048. 
store newspaper promotion more than it does a "real" person. Beneath the flat surface of Warhol's Madonna, however, are formal strategies that go beyond "a set of texts or simulacra;" Raphael I is reminiscent of Byzantine icons of the Virgin Mary.

The Assumption of the Virgin is a scene that is often combined with Mary's Dormition in Byzantine art. ${ }^{278}$ In an icon painted in the fifteenth century by Andreas Ritzos, both of these episodes occur at the same time (figure 37). After falling asleep (Dormition), the Virgin Mary's body and soul are taken into Heaven (Assumption). ${ }^{279}$ In Raphael's Sistine Madonna, the illusionistic rendering of the Virgin's windswept clothing makes her appear as if she is being transported into a heavenly realm. If Warhol's Madonna is rising while her duplicated image below lies in repose, this arrangement of figures may be interpreted as a contemporary icon of Mary's Assumption and Dormition. In Catholicism, Mary's Assumption into Heaven is considered infallible doctrine. No longer a historical figure, after the Assumption Mary exists in a transcendent realm where she is available to receive prayer and devotion. ${ }^{280}$

The Ritzos icon is not based solely on scripture; it portrays a legend carried from early times in combination with tradition that developed over the centuries of Christian belief. As Mary lies on her death bed, she is surrounded by angels and saints, church leaders, bishops, et alia. Around the entire icon there is a glow of gold and red - representing the burst of the heavenly kingdom and the surge of life. The scene is crowded with both earthly and

${ }^{278}$ The Dormition of Mary is literally the falling asleep of Mary, or Mary's death. Although a fifthcentury feast is still celebrated in the East, contemporary theology, particularly in the West, emphasizes the glorification of Mary's body in the Assumption rather than the circumstances surrounding her death. See McBrien, The Harpercollins Encyclopedia of Catholicism, 432. See also Hall, Hall's Dictionary of Subjects and Symbols in Art, 94.

${ }^{279}$ McBrien, The Harpercollins Encyclopedia of Catholicism, 104, 432.

${ }^{280}$ Rosemary Radford Ruether, Mary - The Feminine Face of the Church (Philadelphia: The Westminster Press, 1977), 61. 
heavenly creatures gathered to experience the fulfillment of Christ's word. ${ }^{281}$ In Raphael I, there is also a radiance of gold and red - in the form of an emblazoned price tag. The earthly and heavenly members of creation, the pope and St. Barbara, who gazes down at the two putti in Raphael's painting, may now be seen as witnesses to the Virgin's Dormition as she rests across the bottom of the canvas, and her Assumption as she appears to rise up into the heavens.

In the Ritzos icon, the bed, lined with a brilliant red mattress upon which the Virgin Mary lies, is similar to the bed in icons of the birth of Christ known as the Nativity of Christ (figure 38). Like scenes of Mary's Dormition and Assumption, the Nativity of Christ is shown in a landscape setting. ${ }^{282}$ In icons of this type, Mary is sometimes shown reclining in a manner similar to her Dormition, which suggests that she is resting after the birth. In both Dormition and Nativity icons, the bed is tipped slightly toward the viewer as if it is on a stage, so that Mary may be seen in a frontal view. ${ }^{283}$ Similarly, the resting Virgin in Raphael $I$ (figure 35) does not appear to be reclining in a natural position; she is frontally facing the viewer.

In addition to these similar compositional strategies, Warhol's color choices appear to have been informed by Byzantine traditions. The Madonna and Child, who appear as if they are being raised up into the heavens, are noticeably white. In Byzantine iconography, white represents purity, and those who are filled with divine light. Perhaps Warhol chose to clothe the rising Madonna in blue because in Byzantine iconography, blue and white are the colors of the Virgin Mary, who is detached from this world and centered on the divine. ${ }^{284}$ While the

\footnotetext{
${ }^{281}$ Virginia M. Kimball, "A Reflection on the Feast of the Assumption" (accessed March 19, 2009), http://campus.udayton.edu/mary/images/icons/maria/jpg. 
reclining Madonna, who appears as if she is in Dormition, is completely white, the Christ child in her arms is painted in a bright shade of pink. This calculated placement of color supports a reference to the Nativity in Raphael I; pink is a Rusyn color symbolizing peace, the central theme of Christ's message to the world. ${ }^{285}$ Considering all of these carefully planned compositional and color choices, Raphael I may be viewed as a parallel image of life and death.

In early Christian iconography, simultaneous narration was a way of telescoping subsequent events within the written narrative into a single composition. By the sixteenthcentury in the West, when Raphael painted the Sistine Madonna, simultaneous narration had been largely abandoned. The picture was no longer a showing-forth of the event and its significance; it became more like a single moment frozen in time. ${ }^{286}$ The fact that Warhol chose to omit the wooden ledge which is visible in both Raphael's painting and the encyclopedia illustration is an important indication of the imagery on which he based his interpretation. Byzantine icons avoid any kind of Renaissance illusionistic picture-box, which may explain why the artist excluded this element from his image. ${ }^{287}$ In contrast to the Sistine Madonna, the pictorial space in Raphael I is shallow; this pushes the figures forward toward the viewer. Likewise, the pictorial space in traditional icon painting makes the figures appear as if they are floating in an otherworldly realm. The shallow pictorial space brings the holy being in the viewer's presence. ${ }^{288}$ Utilizing the visual strategies of Byzantine iconographers, Warhol produced a multi-faceted narrative that encapsulated the Virgin's Dormition, Assumption, and the Nativity of Christ into a single composition.

${ }^{285}$ Herbenick, Andy Warhol's Religious and Ethnic Roots: The Carpatho-Rusyn Influence on His Art, 168.

\footnotetext{
${ }^{286}$ Martin, Sacred Doorways: A Beginner's Guide to Icons, 141.

${ }^{287}$ Martin, Sacred Doorways: A Beginner's Guide to Icons, 100.

${ }^{288}$ Martin, Sacred Doorways: A Beginner's Guide to Icons, 134.
} 
In Raphael I, Warhol combines seemingly disparate images: The highest sacred art and the lowliest commercial design. Without taking Warhol's religious background into account, this hybridization would seem to be an irreverent gesture, but as art critic Charles Stuckey observed, by combining the sacred and the profane, Raphael I seems "to suggest that, for a Pop god, the meek and the poor in spirit among artists are no less important than Raphael." 289 Raphael I portrays a whimsical sensibility that does not seem irreverent to Raphael's famous painting or its religious content. ${ }^{290}$ Warhol appropriated the price tag in Raphael I from a retail advertisement for a blouse. ${ }^{291}$ To what is this symbol of mass marketing now referring? Perhaps its placement may provide a clue; the price tag is located in the far top left corner of the canvas, directly behind the head of the pope. This mark of modern consumer culture is placed where the pope's halo should be. A halo is a round glory which traditionally represents a heavenly sphere. Warhol seldom chose an object, image, or logo randomly; the price tag jarringly brings the paternal Holy Father from a heavenly realm into the earthly present. ${ }^{292}$ The strategic placement of this monetary symbol may refer to the financial demands of the Church, and a papacy in which artists like Raphael were commissioned to adorn luxurious papal residences and cathedrals. When Raphael painted the Sistine Madonna, the sale of indulgences paid for the construction of St. Peter's Cathedral in Rome. More significantly, the price tag is to the right of the Madonna and Child, slightly overlapping the figures. This placement may be seen as a reference to the marketing of religious images as decorative objects.

\footnotetext{
${ }^{289}$ Stuckey et al., Andy Warhol: Heaven and Hell Are Just One Breath Away!, 28.

${ }^{290}$ Dillenberger, The Religious Art of Andy Warhol, 57-58.

${ }^{291}$ Stuckey et al., Andy Warhol: Heaven and Hell Are Just One Breath Away!, 28.

292 Dillenberger, The Religious Art of Andy Warhol, 92.
} 
In the mid-1960s, manufacturers detached Catholic objects from their devotional function and marketed them as household decorations. Some Americans began buying Catholic objects such as statues, rosaries, and religious prints for their decorative "camp" and fashion value. Beginning in the 1980s, sacred Catholic objects served as props in the pop star Madonna's (b. 1958) music videos. In 1984, the year before Warhol created Raphael I, Madonna popularized a new role for the rosary by wearing several as costume jewelry in the music video Like a Virgin (figure 39). Fully utilizing Catholic material culture to achieve her commercial and artistic goals, Madonna did not hold the rosary in her hand in gesture of prayer; she instead wore it fashionably around her neck. ${ }^{293}$ By layering rosaries over a white lace dress, Madonna, named for the Virgin, sells the image of Mary - the definitive model of femininity and motherhood - as a marketable commodity. No rosary appears in the encyclopedia illustration that Warhol used for Raphael $I$, but he added one. This addition to his source is significant; the insertion of a hand-painted object to an appropriated image is a highly unusual gesture for Warhol. Perpetually fascinated with the transformation of cultural objects, the artist likely took note of Madonna's commercialization of the Virgin and her attributes in the 1980s, and presented them along with a garish red price tag.

Is it possible that Raphael I contains all of these meanings at once? Heartney argues that it is precisely this ability "to allow ordinary objects to encompass multiple meanings which recurs again and again in the work of artists raised as Catholics."294 Warhol's deceptively simple images are careful constructions that intentionally obscure a more complex vision. He uses banal references that allow for a myriad of interpretations without denying the clichéd nature of the appropriated image. ${ }^{295}$ In his mechanically-produced

\footnotetext{
${ }^{293}$ McDannell, Material Christianity: Religion and Popular Culture in America, 62-64.

${ }^{294}$ Heartney, Postmodern Heretics: The Catholic Imagination in Contemporary Art, 30.

${ }^{295}$ Heartney, Postmodern Heretics: The Catholic Imagination in Contemporary Art, 30.
} 
paintings, Warhol evokes the spiritual complexity of the sacred icon and relates it to the material culture that is such a significant component of American life.

Less than one year after he created Raphael I, Warhol accepted an unusual request from art dealer Alexandre Iolas: create a series of paintings based on another Renaissance masterpiece, Leonardo da Vinci's The Last Supper (1495-97/98, figure 1). This last major series of Warhol's career clearly illustrates how the imagery, customs and rituals of Byzantine Catholicism affected his thought process, encompassed his issues with death, and motivated his creation of icons imbued with the real presence of what is depicted.

\section{Chapter XV: The Last Supper}

When his Last Supper was displayed in Milan, a kind of citywide twoman show with Leonardo, 30,000 people flocked to see it . . When the final multivolume Popular History of Art is published, ours will be the Age of Warhol - an unlikely giant, but a giant nonetheless.

$$
\text { Arthur Danto } 296
$$

In early 1986, nearly a year before his death, Warhol pursued the most ambitious undertaking of his career - The Last Supper series. The series was exhibited in Iolas' newlypurchased gallery space across from Santa Maria delle Grazie, the site of Leonardo's original. Warhol exceeded the art dealer's expectations and created more than one-hundred versions, thirty of which were monumental in size. The commission must have appealed to Warhol on many levels; he was an artist who consistently devoted himself to subjects that were common, mass-produced, and instantly recognizable. The artist had been well acquainted with early nineteenth-century reproductions of The Last Supper from a very young age; a copy hung in the Warhola kitchen in Pittsburgh. ${ }^{297}$ At the time the commission was offered to Warhol, the original was receiving a significant amount of public attention. In

\footnotetext{
${ }^{296}$ As quoted in Dillenberger, The Religious Art of Andy Warhol, 101.

${ }^{297}$ Dillenberger, The Religious Art of Andy Warhol, 80.
} 
1986, the fading, brittle, and decaying mural was undergoing yet another restoration. The Last Supper had become a popular subject again, frequently appearing in the media. Taking on one of the most commercially-successful historical religious paintings when it was receiving so much publicity must have been an irresistible challenge.

Although the commission allowed the artist to acknowledge his religious beliefs, he publicly denied that the works held any personal significance, insisting, "I'm still a commercial artist. I was always a commercial artist. ${ }^{, 298}$ When the formal decisions and strategies Warhol employed throughout the series are analyzed, however, it is clear that he was quite serious in his approach to one of the most powerful images in the history of Western art, and a scene beloved by Christians. As curator Joseph Kentner observed, "It is a rarity in the history of modern and contemporary art for an avant-garde artist to treat religious subjects with the sincerity of his or her personal convictions." ${ }^{299}$ Warhol's Last Supper series includes some of the largest religious works by any American painter, rivaled only by John Singer Sargent's mural of religious history in the Boston Public Library. ${ }^{300}$

Like his version of Raphael's Sistine Madonna, Warhol's rendition of Leonardo's Last Supper is more evocative of the art of the Byzantine era than that of the Renaissance. Byzantine art is often compared with the religious art of the West and, as a result, it has historically been misunderstood and even dismissed as flawed, primitive, and unnatural. While Western art has been admired for its naturalism, for presenting "real" physiognomies and environments, Byzantine art has been criticized for its weakness in rendering natural reality, natural beauty, grace and variety. ${ }^{301}$ According to theologian Gennadios Limouris:

\footnotetext{
${ }^{298}$ Ketner, Andy Warhol: The Last Decade, 37.

${ }^{299}$ Ketner, Andy Warhol: The Last Decade, 37.

${ }^{300}$ Joshua Delpech-Ramey, “The Idol as Icon: Andy Warhol's Material Faith,” Angelaki, Journal of the Theoretical Humanities 12 (2007): 96.

${ }^{301}$ Limouris, Icons: Windows on Eternity, 96.
} 
In order for the art to express this work of grace which the Church proclaims, it was necessary that even its form be analogous. For this reason, the iconographies which tried to express the holiness of the persons could not have been mere portraits, that is, pictures which direct us to natural people. Rather, they had to have a particular morphological conception so that the onlooker was uplifted from the transience of this world and endowed with the idea of the reborn creation, the transfigurated creation of the eternal world, of the Kingdom of God. ${ }^{302}$

It is in the eternal kingdom of God that the value of Byzantine art lies, and it is this concept of transfiguration which Warhol based not only the last paintings of his career, The Last Supper, but all of his iconic images of the twentieth-century.

One of The Last Supper paintings is in the permanent collection of the Andy Warhol Museum in Pittsburgh, a 9' 8" x 32' 9"' double version entitled The Last Supper (Pink) (1986, figure 40). The grand scale of this canvas is very close to that of Leonardo's, inviting viewers to compare it with the original. Ironically, the large scale of The Last Supper series may be seen as an inheritance of the Abstract Expressionists; it also figures into the contextual games the artist had played since the beginning of his career. For example, Dick Tracy (1960, figure 7) is seven feet high, while Superman (1961) and Peach Halves (1960) stand just under six feet. More than any alteration to their two-or three-inch square sources, it was the painting's large dimensions - the images removed from the comic strip and the classified section and blown-up almost beyond recognition - that make them so striking. Despite his attack on the modernist notion of the spontaneous, original work of art, The Last Supper paintings, like all Warhol's work, must be experienced in person to get the full effect. $^{303}$

For most Americans, Leonardo's masterpiece is not known from the original in Italy; it is recognized from small-scale reproductions such as book illustrations or religious

\footnotetext{
${ }^{302}$ Limouris, Icons: Windows on Eternity, 96-97.

${ }^{303}$ Scherman and Dalton, Pop: The Genious of Andy Warhol, 50.
} 
souvenirs. For Americans familiar with duplications and mass-produced tschotskes, it is surprising to see them transformed back into monumental paintings. ${ }^{304}$ The image that was used for most of the series was a small turn-of-the-century chromolithograph, which Warhol scaled up to dramatic proportions. ${ }^{305}$ In The Last Supper (Pink) (figure 40), two separate images of the same photograph were silkscreened in sections side by side, in black ink over a pink acrylic ground. The coverage of black ink throughout the canvas is inconsistent, making some areas of the painting darker than others. Not only does this tonal variation mimic the condition of Leonardo's famously decaying original, but it also lends a vintage, film-like quality to the piece, giving the impression that this is a depiction of a documented historic event.

The doubled image of Christ may symbolize the two natures of Christ as divine and human, a crucial theological doctrine Warhol would have known from his earliest childhood. The Liturgy of St. John Chrysostom stressed the divinity and the humanity of Christ; which Warhol recited with other worshippers every week. Chrysostom presented the relationship of the two natures as a union and conjunction, but not a confusion. When he distinguished the humanity of Christ from his divinity, he was identifying not a distinct human nature, but rather as the incarnate nature of Christ as both human and divine. ${ }^{306}$ The joining together of two identical images into one painting vividly reinforces this fundamental theological concept.

Another reason for creating a double version may have been that in the biblical account of the story, two crucial events occur simultaneously: Christ is introducing the Eucharist, as well as announcing the presence of a traitor. The apostles react in various ways as they hear

\footnotetext{
${ }^{304}$ Gregory Volk, “The Late, Great Andy Warhol,” in Andy Warhol: The Last Decade, ed. Ketner, 84.

${ }^{305}$ Ketner, Andy Warhol: The Last Decade, 37.

${ }^{306}$ Carey et al, "Chrysostom, John, Saint, Patriarch of Constantinople” (accessed March 18, 2008), http://vnweb.hwwilsonweb.com.
} 
Christ's words: "Verily I say unto you, that one of you shall betray me. And they were exceeding sorrowful, and began every one of them to say unto him, Lord, is it I?"307 By doubling the composition, one of his familiar formal devices, Warhol succeeded in depicting the two elements of communion which are enforced with the words of Christ:

And as they were eating, Jesus took bread, and blessed it, and brake it, and gave $i t$ to the disciples, and said, Take, eat; this is my body. And he took the cup, and gave thanks, and gave it to them, saying, Drink ye all of it; For this is my blood of the new testament, which is shed for many for the remission of sins. ${ }^{308}$

As a Byzantine Catholic, Warhol was likely aware of The Communion of the Apostles (figure 5), an icon that often takes the place of the image of The Last Supper common in western tradition (see page 16). In most icons of this type, Christ is pictured twice, handing the chalice of wine to the group on one side and the bread to the other, an example of simultaneous narration. This particular iconographic representation is one of Christ, the eternal High Priest, offering His Body and Blood to the whole world symbolized by his disciples. $^{309}$

When Warhol attended Mass with his family, he participated in the Anaphora, a Eucharistic prayer (see page 21). During the Anaphora, a call and response dialogue transpires between the congregation and the priest: "Let us lift up our hearts," "We lift them up to the Lord," "Let us thank the Lord," "It is proper and right."," The prayer takes place below the icon of The Last Supper displayed over the doors through which the sacrament is delivered to the congregants (figure 6). The response to the icon is guided and controlled by the Liturgy, creating an emotionally charged environment. Participating in the Anaphora

\footnotetext{
${ }^{307}$ Matthew 26:21-22 (KJV)

${ }^{308}$ Matthew 26:26-28 (KJV)

${ }^{309}$ Unknown author, "Iconography" (accessed April 28, 2008), http://www.stgeorgedowney.org/iconography.html.

${ }^{310}$ Cory and Hollerich, The Christian Theological Tradition, 201.
} 
while gazing at The Last Supper icon helps worshippers to visualize the last meal Christ shared with his apostles. In The Last Supper (Pink), Warhol returned to the pattern that he knew best - the cadence and repetitions of the Liturgy - and doubled the image.

A mystical interpretation of the Last Supper is represented in The Camouflage Last Supper (1986, figure 41). In this extraordinary painting, the camouflage patterned ground beneath the image of Christ and his apostles covers all of the massive thirty-three foot wide canvas. The iconography of Leonardo's painting is so complex that it has been endlessly scrutinized since its inception. Warhol's version in camouflage may be perceived as a metaphor for the multiple ways in which the original is interpreted; it vividly calls attention to different parts of Leonardo's puzzle. The puzzle-like character of camouflage also affirms the perplexed reactions of the apostles. Warhol achieved with camouflage what Leonardo did in his Last Supper. As Giorgio Vasari (1511-1574) eloquently wrote in his Life of Leonardo:

[He] has succeeded in expressing the desire that has entered the minds of the apostles to know who is betraying their Master. So in the face of each one may be seen love, fear, indignation, or grief at not being able to understand the meaning of Christ. ${ }^{311}$

It was observed by Ultra Violet (b. 1935), an actor who frequently appeared in Warhol's films, that he "idolized the Church's magic." 312 In the Byzantine tradition, the icon is regarded as a mysterion, a sacred mystery. Perhaps Warhol chose to create a version in camouflage because he knew that in Eastern Rite Church theology, the sacrament of the Last Supper is referred to as the "Mystical Supper."313

\footnotetext{
${ }^{311}$ Giorgio Vasari, "Giorgio Vasari: The Lives of the Artists, 1568” (accessed April 3, 2007), http://www.fordham.edu.

${ }^{312}$ Herbenick, Andy Warhol's Religious and Ethnic Roots: The Carpatho-Rusyn Influence on His Art, 99.

${ }^{313}$ Herbenick, Andy Warhol's Religious and Ethnic Roots: The Carpatho-Rusyn Influence on His Art, 99.
} 
The Gospel of Mark describes the location of the Last Supper in a "guestchamber," a "large upper room furnished and prepared." 314 In Leonardo's mural, the artist approached the scene as if it were set on a stage above the heads of those dining in the refectory (figure 1). By approaching the mural as a stage performance in a Renaissance theater, Leonardo was able to provide the monks and the prior dining in the refectory with the opportunity to participate in the action above them. ${ }^{315}$ Warhol's monumental composition encompasses the viewer's entire field of vision, bringing to mind the "large upper room" in which the Passover meal took place, and providing a similar sensation to what the monks experienced in the refectory centuries ago.

Since the photograph that Warhol used in his Last Supper series was of a nineteenthcentury reproduction, it contains gratuitous additions and changes to Leonardo's original. ${ }^{316}$ The existing doors of the refectory, which are present in photographs of the mural, are absent in Warhol's adaptations (figure 40). Although there are no doors in icons of The Last Supper, in Byzantine churches, the sacrament of the Last Supper is represented above the central Royal Doors of the iconostasis (figure 6), immediately above where communion takes place. ${ }^{317}$ After the doors are opened, the sacrament is delivered to the members of the congregation. The Last Supper scene continues down from the icon as communion is served -as the assembly participates in His body and His divinity. ${ }^{318}$

Although Warhol did not participate in communion as an adult in New York, he observed the ritual from his seat in the nave. The consecration of the Eucharistic elements

\footnotetext{
${ }^{314}$ Mark 14:14-15 (KJV). See also Leo Steinberg, Leonardo's Incessant Last Supper (New York: Zone Books, 2001), 171.

${ }^{315}$ Lillian F. Schwartz, “The Staging of Leonardo’s "Last Supper”: A Computer-Based Exploration of Its Perspective," Leonardo 1 (1998): 91.

${ }^{316}$ Dillenberger, The Religious Art of Andy Warhol, 103.

${ }^{317}$ Ouspensky and Lossky, The Meaning of Icons, 68.

${ }^{318}$ According to Saint John of Damascus. See Ouspensky and Lossky, The Meaning of Icons, 68.
} 
occurred behind the iconostasis, which undoubtedly made communion a mystical experience for Warhol. Camouflage, a military pattern that helps to hide soldiers and weapons of war in the landscape, serves the same purpose as the iconostasis does in churches like St. John Chrysostom Byzantine Catholic Church; it both hides and enforces the Byzantine Catholic theology of the Mystical Supper.

One of the most intriguing versions of The Last Supper was not a silkscreen from a photograph, but a painting from a line drawing. In The Last Supper (Dove) (1986, figure 42), Warhol drew an image from one of the replicas he purchased, projected it onto a twenty-two foot wide canvas, and traced over it. ${ }^{319}$ The scene is painted in black on a pale gold ground, with various commercial product logos superimposed over the sacred image in red, pink and blue. Since Warhol seldom chose an object, image, or logo randomly, the placement of these elements must be examined. ${ }^{320}$ A large red price tag is located in the far top left corner of the canvas near Judas, the disciple who betrayed Jesus for a payment of thirty pieces of silver. In Leonardo's Renaissance version of the Last Supper, the artist portrayed Judas as the only figure in the painting with dark skin, signifying his guilt (figure 1); in Warhol's Pop adaptation, a bold red price tag is what calls attention to the guilty apostle (figure 42).

A pink Dove Soap logo is to the right of the price tag, the dove portion hovering over Christ's head in the center. The dove is a traditional symbol of peace, as well as a Christian symbol for the Holy Spirit. In the scriptural account of Christ's baptism, "the heavens were opened unto him, and he saw the Spirit of God descending like a dove, and lighting upon him." 321 Dove Soap suggests water; for Byzantine Catholics, immersion in water symbolizes not only death and purification, but also regeneration and renewal. In the Book of Acts, the

\footnotetext{
319 According to Bourdon, The Last Supper (Dove) was not exhibited in Milan; Warhol chose to show only silkscreened versions in the exhibition. See Bourdon, Warhol, 406.

${ }^{320}$ Dillenberger, The Religious Art of Andy Warhol, 92.

${ }^{321}$ Matthew 3:16 (KJV). See also Dillenberger, The Religious Art of Andy Warhol, 93.
} 
apostle Peter preaches before a large gathering, encouraging them to "Repent, and be baptized every one of you in the name of Jesus Christ for the remission of sins, and ye shall receive the gift of the Holy Ghost." Dove Soap may be seen as a representation of the two principal effects of baptism: purification from sins and new birth in the Holy Spirit. ${ }^{322}$

A large blue General Electric logo is placed on the far right side of the canvas. The company's slogan is "We bring good things to light." Perhaps Warhol's placement of this corporate symbol of illumination is in reference to the shaft of light which illuminates the right wall in the room of Leonardo's Last Supper (figure 1). The General Electric logo may also be seen as a metaphor for creation. God said "Let there be light: and there was light. And God saw the light, that it was good." ${ }^{323}$ With General Electric as a symbol for the Creator, and the pink dove for the Holy Spirit, the two combined with the figure of Jesus comprise the Holy Trinity (figure 42). ${ }^{324}$ In The Last Supper (Dove), religious iconography was brought into the painting in the form of mechanically-produced, highly recognizable commercial product logos that reinforce the religious meaning behind the Renaissance masterpiece. $^{325}$

In Sixty Last Suppers (1986, figure 43), Leonardo's painting received the same treatment as the Campbell's Soup can in Warhol's series of the 1960s (figure 44). Sixty Last Supper photographs were repeatedly silkscreened in black ink on a white ground and stacked from edge to edge of the canvas, which is, once again, similar in size to the original, thirtytwo feet wide (figure 45). This classically Warholian composition is typically interpreted as a reference to the desensitizing effect of repeated images in the media on society.

\footnotetext{
${ }^{322}$ Acts 2:38 (KJV). See also unknown author, "Grace of Baptism" (accessed April 29, 2008), http://www.stgeorgedowney.org/iconography.html.

${ }^{323}$ Genesis 1:3-4a $(K J V)$.

${ }^{324}$ Dillenberger, The Religious Art of Andy Warhol, 93.

${ }^{325}$ Herbenick, Andy Warhol's Religious and Ethnic Roots: The Carpatho-Rusyn Influence on His Art, 100.
} 
Depreciation of the image is an intrinsic component in much of Warhol's work, but this painting takes the viewer far beyond that interpretation. Sixty Last Suppers brings to mind the daily repetition of the sacrament of Holy Communion as a Christian remembrance of the biblical account of the Last Supper. ${ }^{326}$

Byzantine Catholics bless themselves three times during the celebrations of the Mass as a symbol of the Last Supper, sing Alleluia three times, and petition the Lord three times, praying "Lord have mercy, Lord have mercy, Lord have mercy." Considering Warhol's ethnic origins and religious practices, it would be surprising if his artwork lacked repetition. ${ }^{327}$ He was exceedingly familiar with repetition as a major part of the church life in which he took part as a child and continued to observe throughout his adulthood. Rituals such as the observance of the same religious feasts each year, grace before each meal, and the prayers that were recited in the same manner over and over again had a profound effect on Warhol's work.

\section{CONCLUSION}

The knowledge of [his] secret piety inevitably changes our perception of an artist who fooled the world into believing that his only obsessions were money, fame, (and) glamour, and that he was cool to the point of callousness. Never take Andy at face value. -John Richardson, "Eulogy for Andy Warhol",328

Throughout his career, art critics and theorists scorned Warhol's incessant repetition of appropriated imagery and insisted that his flat, two-dimensional compositions lacked the emotional depth and originality found in those of his modernist predecessors. Expounding

\footnotetext{
100.

${ }^{326}$ Herbenick, Andy Warhol's Religious and Ethnic Roots: The Carpatho-Rusyn Influence on His Art,

${ }^{327}$ Herbenick, Andy Warhol's Religious and Ethnic Roots: The Carpatho-Rusyn Influence on His Art, 21, 69.

${ }^{328}$ Herbenick, Andy Warhol's Religious and Ethnic Roots: The Carpatho-Rusyn Influence on His Art, 40.
} 
the virtues of Abstract Expressionism's transcendental power, art critic Clement Greenberg (1909-1994), the high priest of modernism, dismissed Pop art as "kitsch" and the antithesis of what fine art should aspire to be. This attitude was shared by some postmodernists; cultural theorist Roland Barthes (1915-1980) saw little referential depth and subjective import in the sheer superficiality of Pop. "What Pop art wants," wrote Barthes, "is to desymbolize the object," in other words, to release the image from deep meaning into simulacral surface. ${ }^{329}$ By overlooking Warhol's cultural background and believing his disingenuous claim that "there's nothing behind it," Greenberg, Barthes, Jameson, and countless others failed to recognize the intimate way in which Warhol experienced images and, consequently, they missed the nuanced symbolism in his work. Warhol's relationship with his Pop images is comparable to the believer's relationship with the Byzantine icon - it is transcendental.

The influence of Byzantine Catholicism in the art of Andy Warhol extends far beyond a mere fascination with religious iconography; it encompasses his fixation with looking, his need for participation, and his desire to "be a machine." In the profane, Warhol finds the sacred - a theosis of humanity that lies at the heart of Byzantine art. As if channeling a Byzantine iconographer, Warhol repeatedly imprinted the very essence of his subject on a large field of luminous color, transforming it into a real presence and producing a profound and lasting memory. This new reading of some of Warhol's late work - Skull, Shadows, Oxidation, Raphael I-6.99, and The Last Supper - sets the stage for a deeper investigation of the artist's entire body of work; it provides an opportunity to re-evaluate his early drawings, films, and multi-media Exploding Plastic Inevitable to view them in a new light. Without taking his relationship with Byzantine Catholicism into account, we will fail to understand the deepest aspects of Warhol's relationship with the visual image.

\footnotetext{
${ }^{329}$ Foster, "Death in America," 38.
} 


\section{FIGURES}

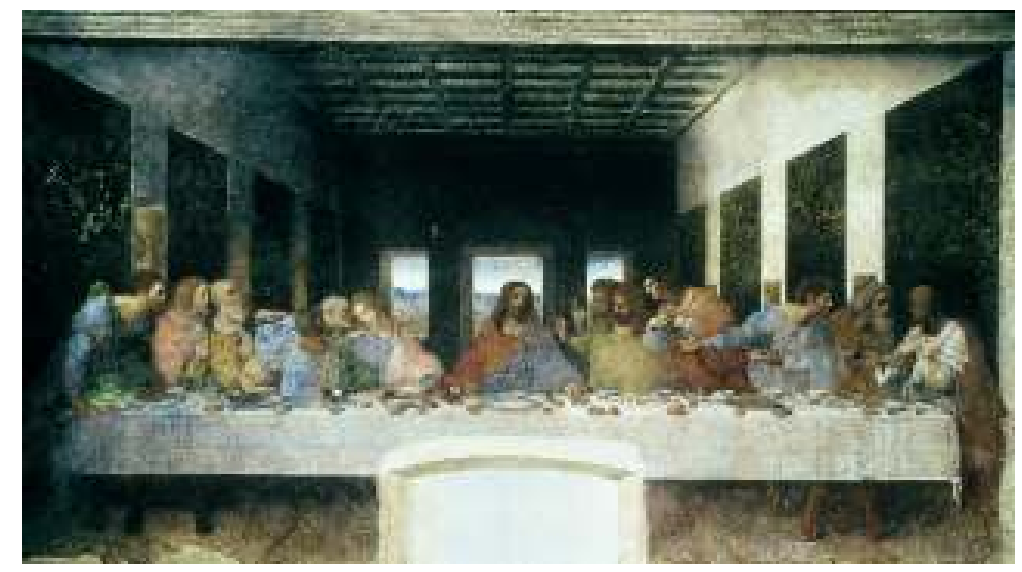

Figure 1:

Last Supper, 1495-97/98

Leonardo da Vinci

Painting, $460 \mathrm{~cm} \mathrm{x} 880 \mathrm{~cm}$

Refectory of the Convent of Santa Maria delle Grazie, Milan

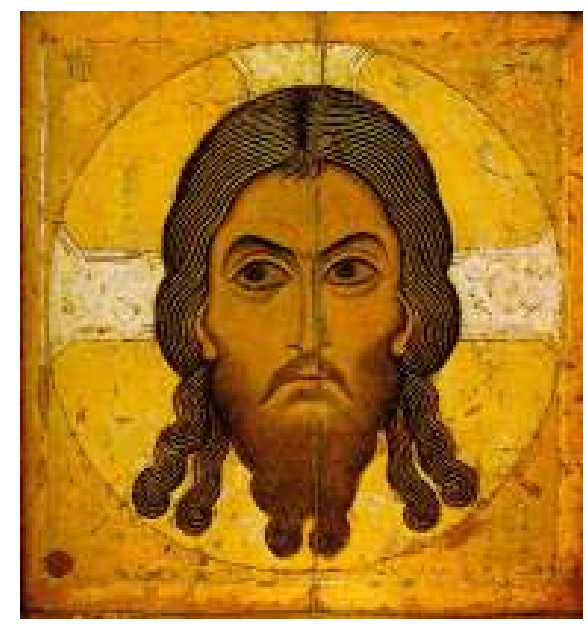

Figure 2:

Icon of The Holy Face (Acheiropoietos)

Moscow School, $12^{\text {th }}$ Century 


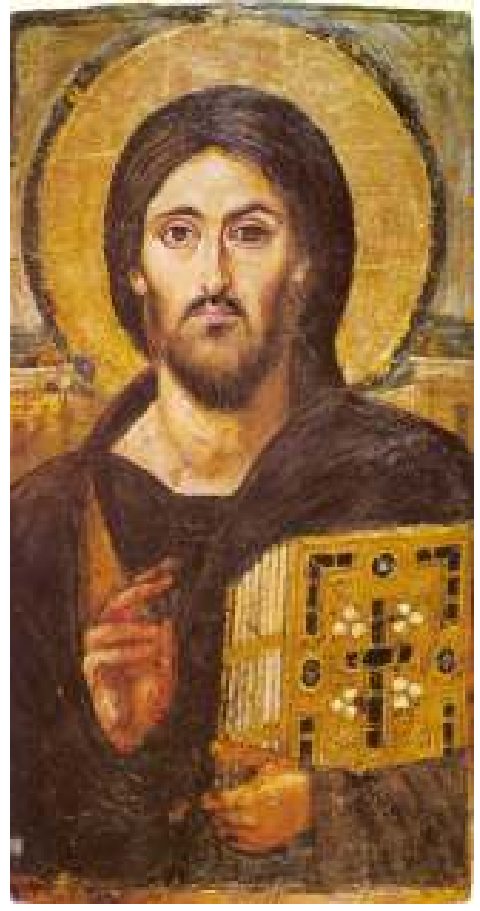

Figure 3:

Icon of Christ Pantocrator Byzantine $6^{\text {th }}$ Century St. Catharine's, Sinai

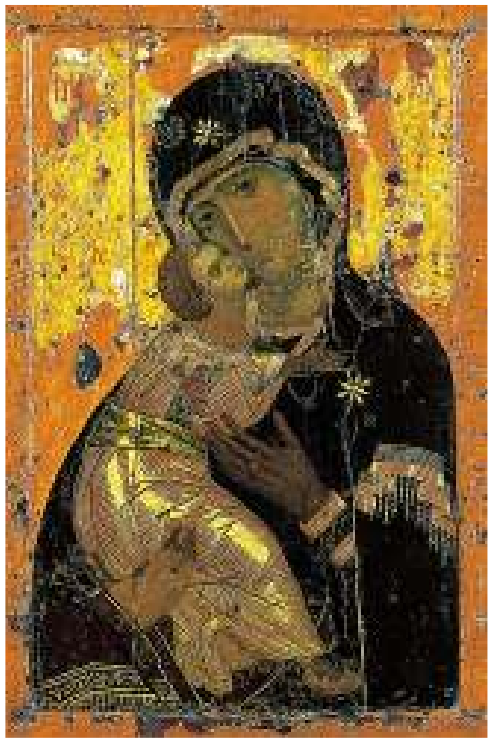

Figure 4:

Icon of Virgin of Vladimir

Painted wood, $301 / 2 \times 21$ in Byzantine, $12^{\text {th }}$ Century

Tretiakov National Art Gallery, Moscow 


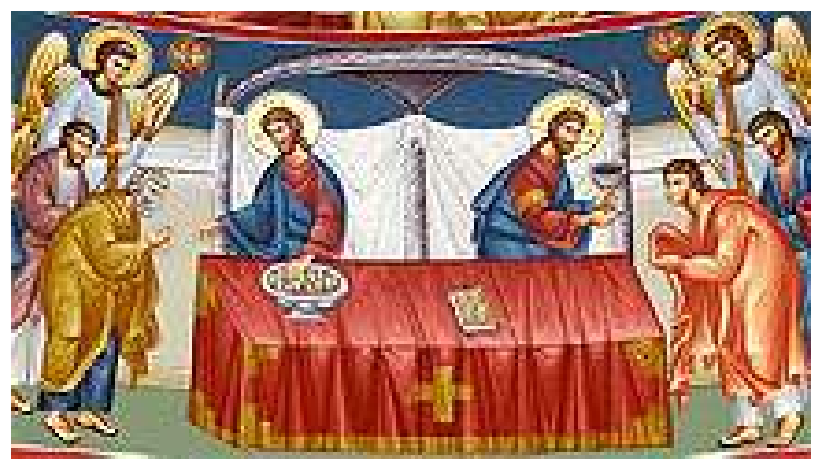

Figure 5:

Icon of The Communion of the Apostles

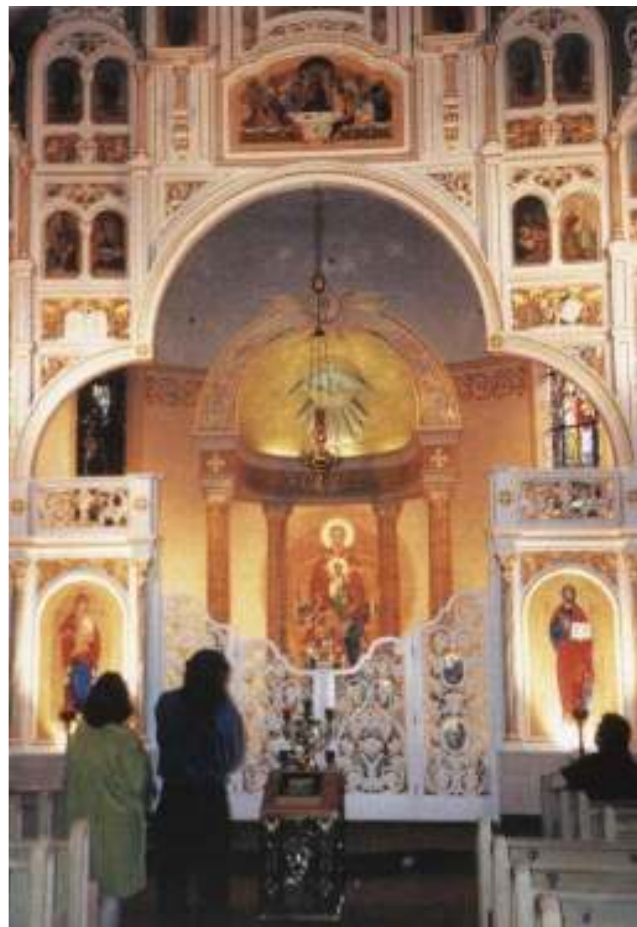

Figure 6:

Original Iconostasis in St. John Chrysostom Byzantine Catholic Church, Pittsburgh 


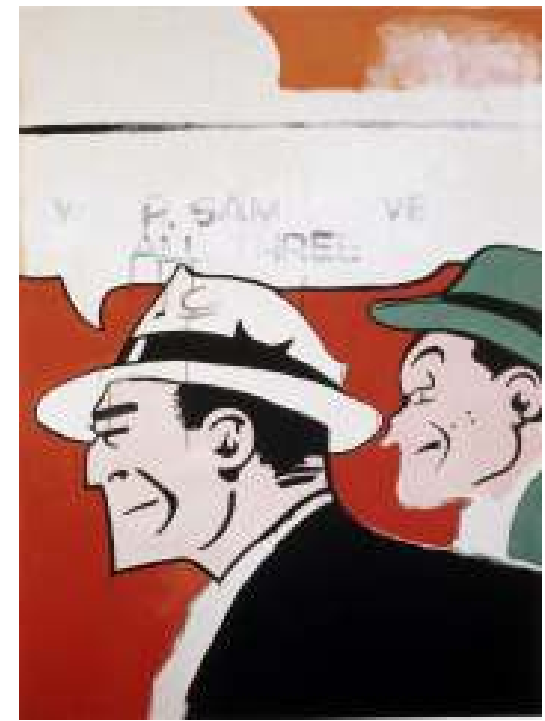

Figure 7:

Dick Tracy, 1960

Andy Warhol

Acrylic on canvas, $79 \times 45$ in

Collection of Mr. and Mrs. S.I. Newhouse, Jr., New York

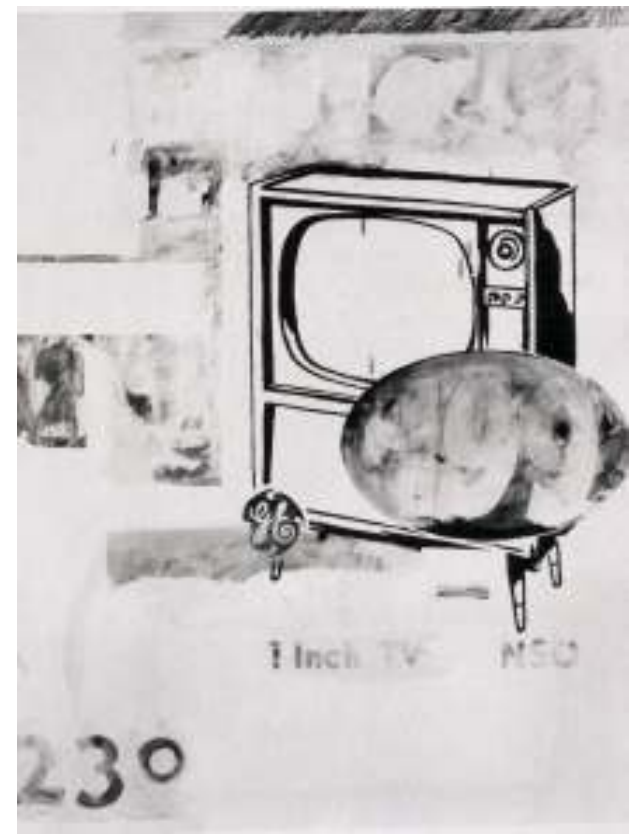

Figure 8:

$T V \$ 199,1960$

Andy Warhol

Oil and wax crayon on canvas, $62.5 \times 49.5$ in

Collection of John and Kimiko Powers 


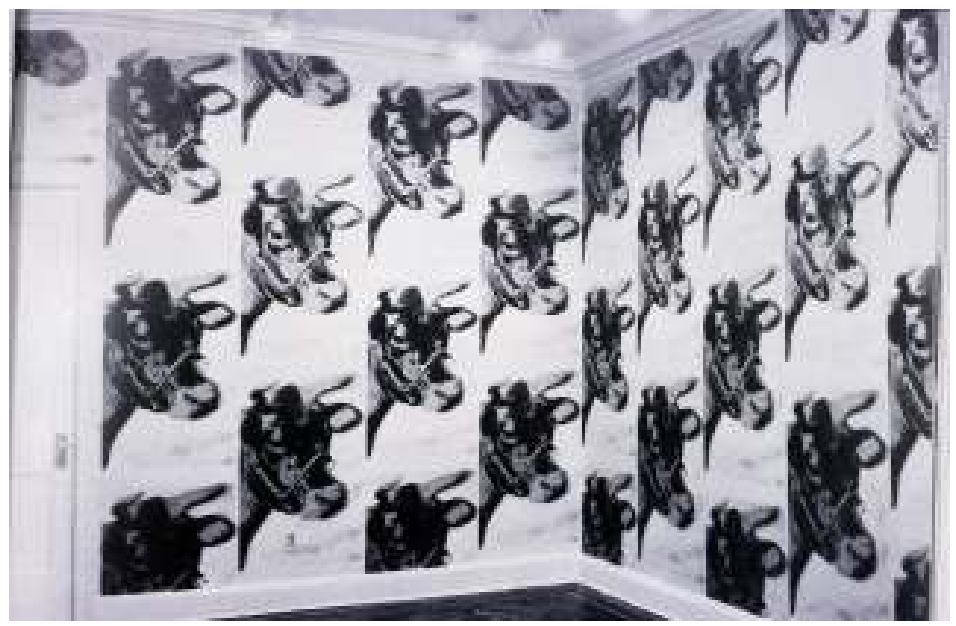

Figure 9:

Cow Wallpaper (installation), 1966

Andy Warhol

Leo Castelli Gallery, New York

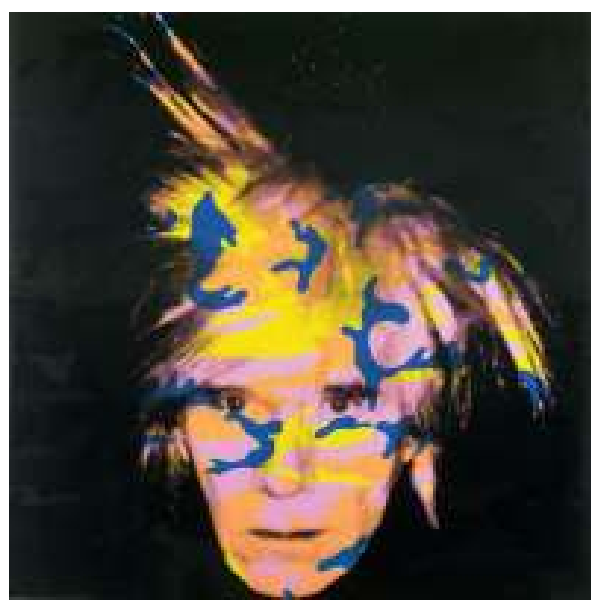

Figure 10:

Self-Portrait, 1986

Andy Warhol

Acrylic and silkscreen ink on linen, 203.5 x $203.5 \mathrm{~cm}$

The Andy Warhol Museum, Pittsburgh 


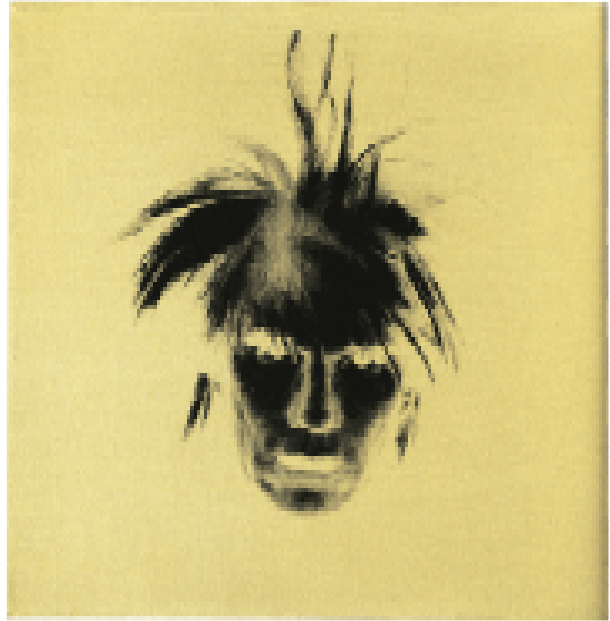

Figure 11:

Self-Portrait, 1986

Andy Warhol

Acrylic and silkscreen ink on linen, 35.6 x $35.6 \mathrm{~cm}$

The Andy Warhol Museum, Pittsburgh

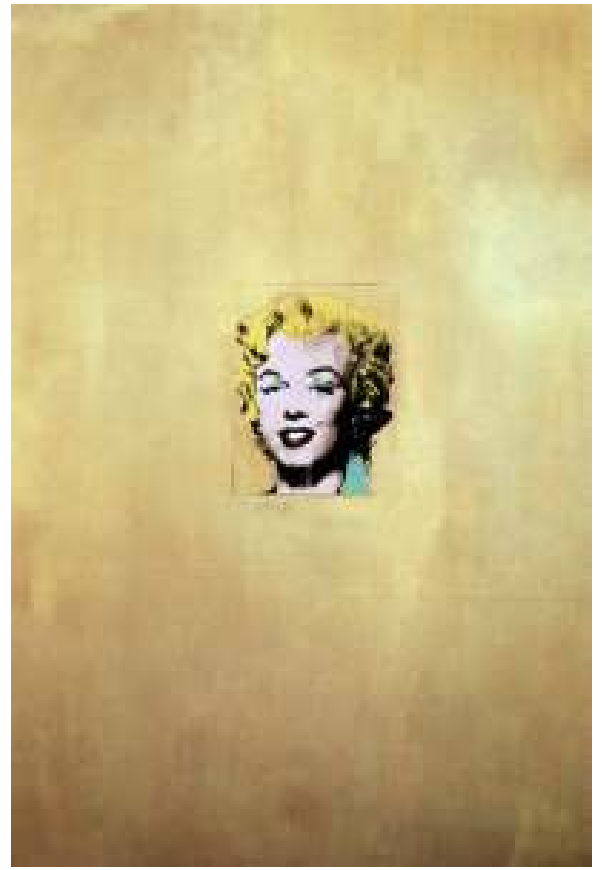

Figure 12:

Gold Marilyn Monroe, 1962

Andy Warhol

Acrylic, oil, and silkscreen on canvas, 83 1/4 x 57 in The Museum of Modern Art, New York 


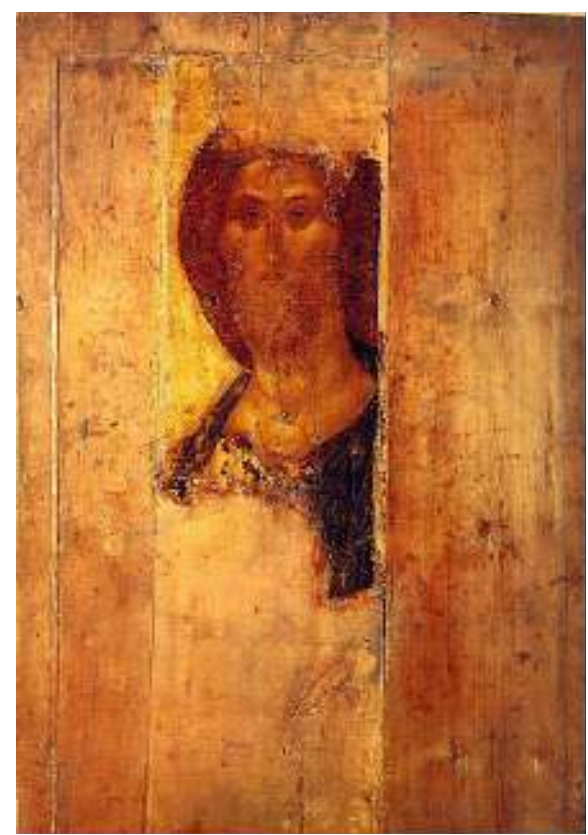

Figure 13:

Icon of Christ the Redeemer Andrei Rublev

Tretyakov Gallery, Moscow

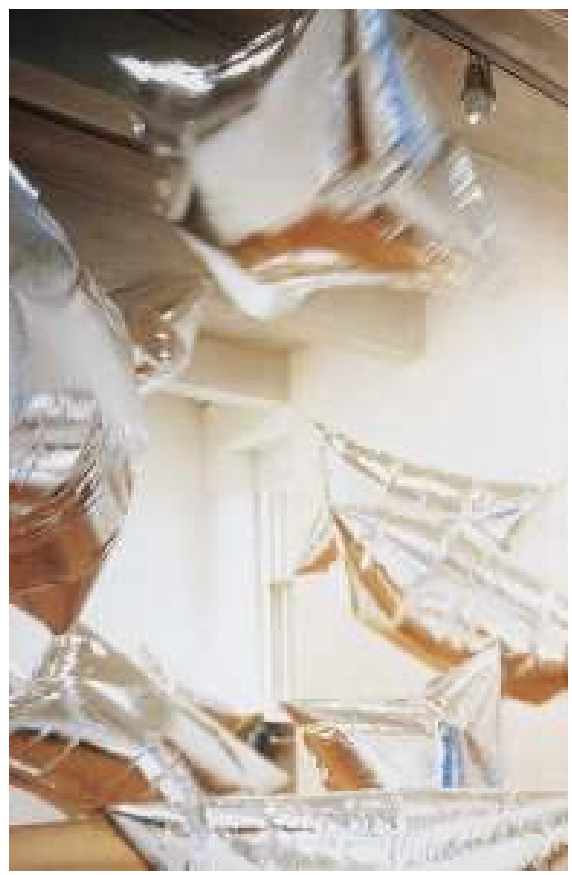

Figure 14:

Silver Clouds (installation), 1966 Andy Warhol

Helium-filled metalized plastic Andy Warhol Museum, Pittsburgh 


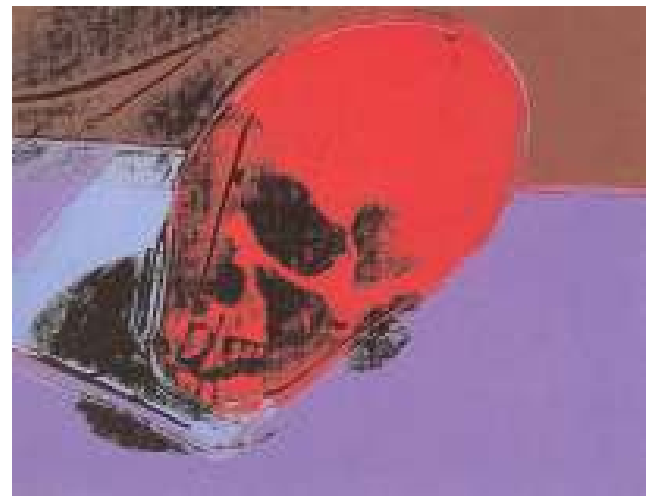

Figure 15:

Skull, 1976

Andy Warhol

Synthetic polymer paint and silkscreen on canvas, $15 \times 19$ in The Andy Warhol Foundation for the Visual Arts, New York

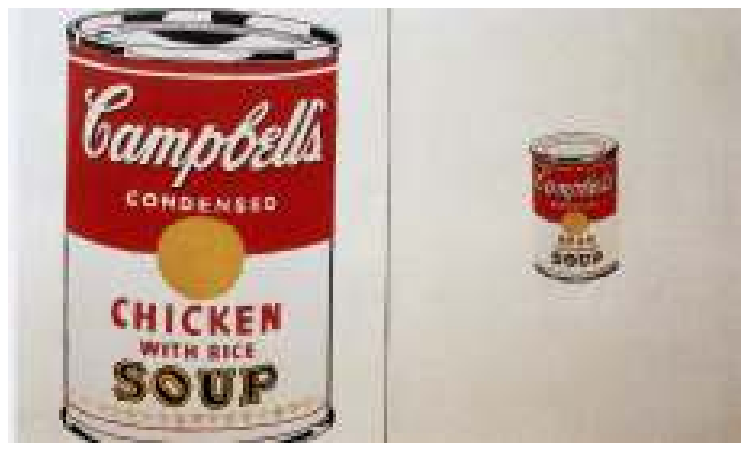

Figure 16:

Campbell's Soup Cans (Chicken with Rice, Bean with Bacon), 1962 Andy Warhol

Acrylic on canvas, two panels, each $20 \times 16$ in Stadisches Museum Abteiberg, Monchengladbach 


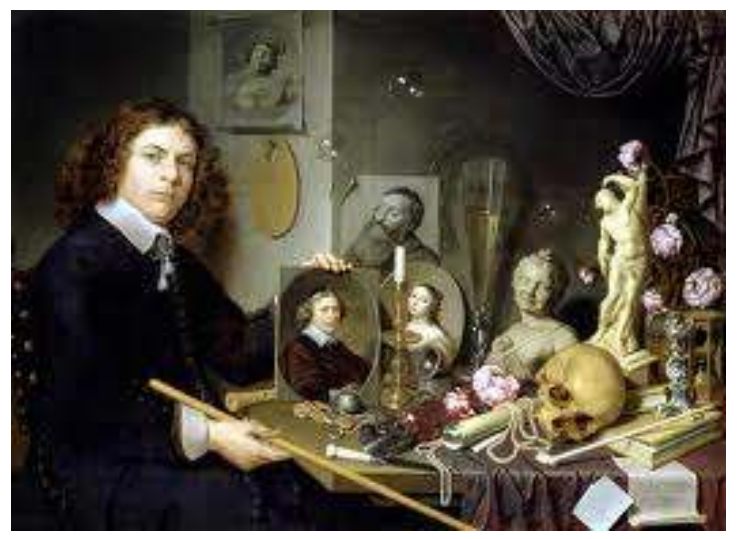

Figure 17:

Vanitas Still-life with a Portrait of a Young Painter, 1651

David Bailly

Oil on panel, $93 \times 124 \mathrm{~cm}$

Stedelijk Museum De Lakenhal, Leiden

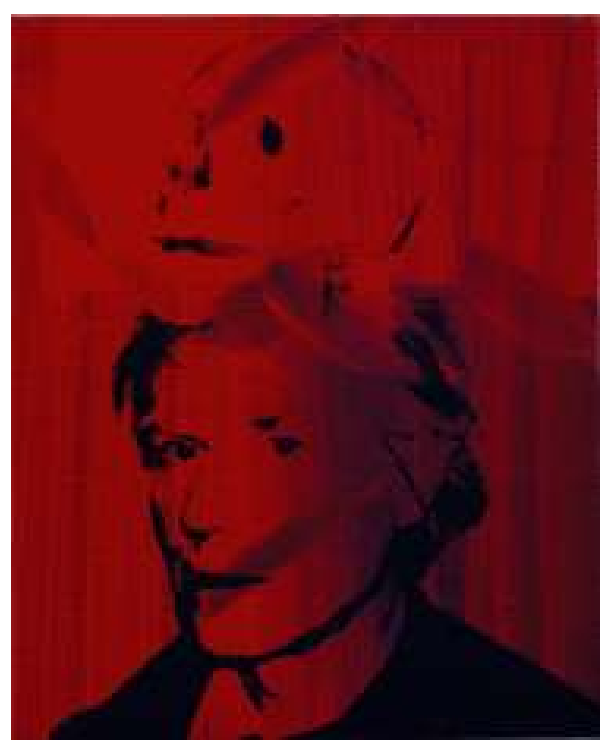

Figure 18:

Self-Portrait with Skull, 1978

Andy Warhol

Acrylic and silkscreen ink on canvas, $40.6 \times 33 \mathrm{~cm}$

Tate and National Galleries of Scotland 


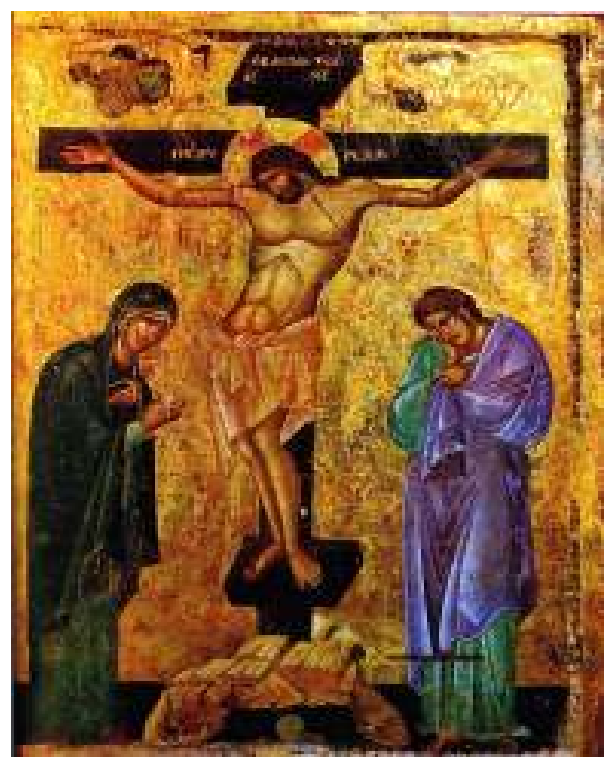

Figure 19:

Icon of The Crucifixion

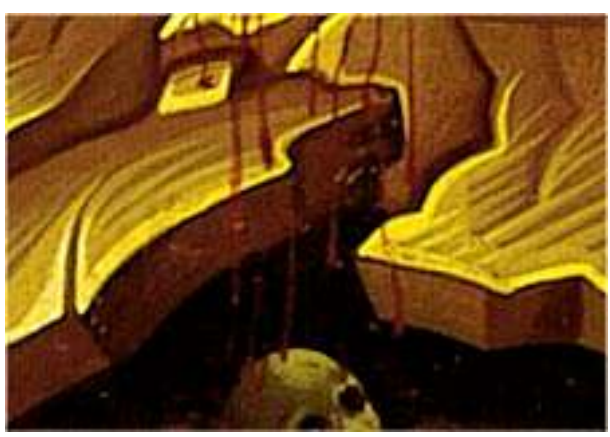

Figure 20:

Icon of The Crucifixion (detail) 


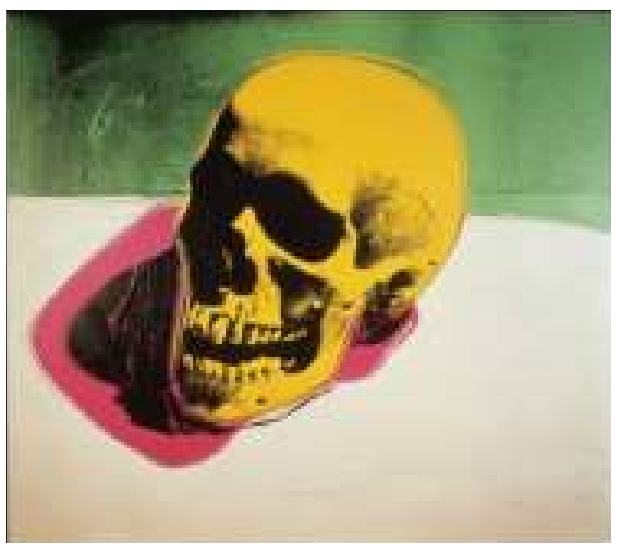

Figure 21:

Skull, 1976

Andy Warhol

Synthetic polymer paint and silkscreen on canvas, $15 \times 19$ in The Andy Warhol Foundation for the Visual Arts, New York

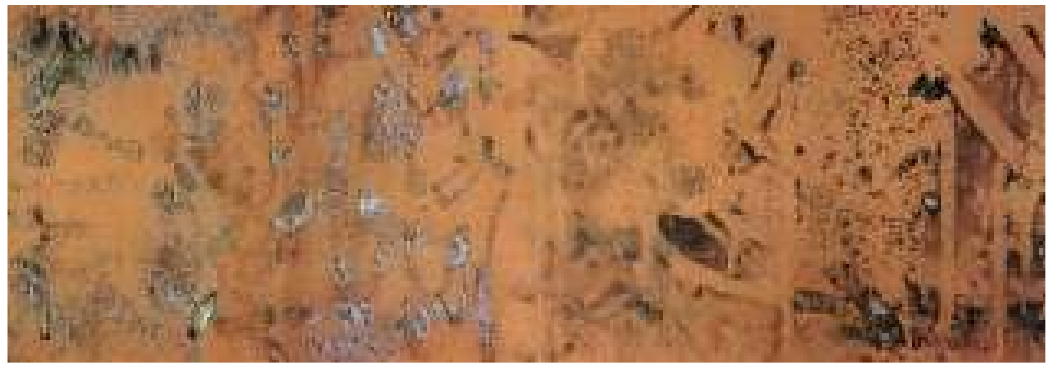

Figure 22:

Oxidation Painting, 1978

Andy Warhol

Copper paint and urine on canvas, $198 \times 528 \mathrm{~cm}$

Bischofberger Collection, Switzerland 


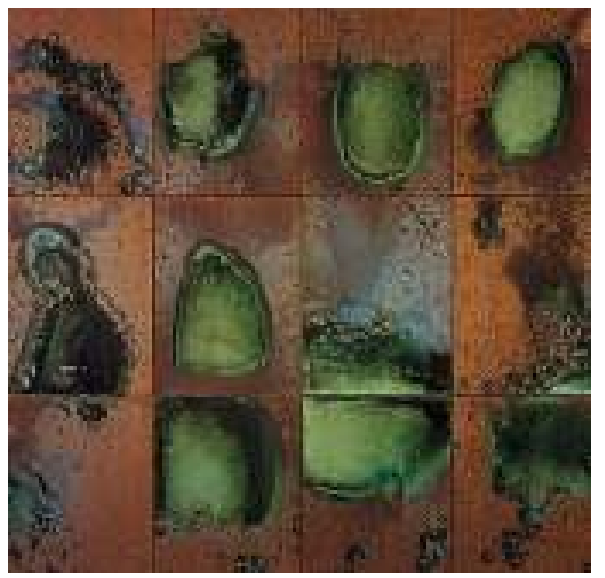

Figure 23:

Oxidation Painting (in 12 parts), 1978

Andy Warhol

Acrylic and urine on linen, 121.9 x $124.5 \mathrm{~cm}$

The Andy Warhol Museum, Pittsburgh

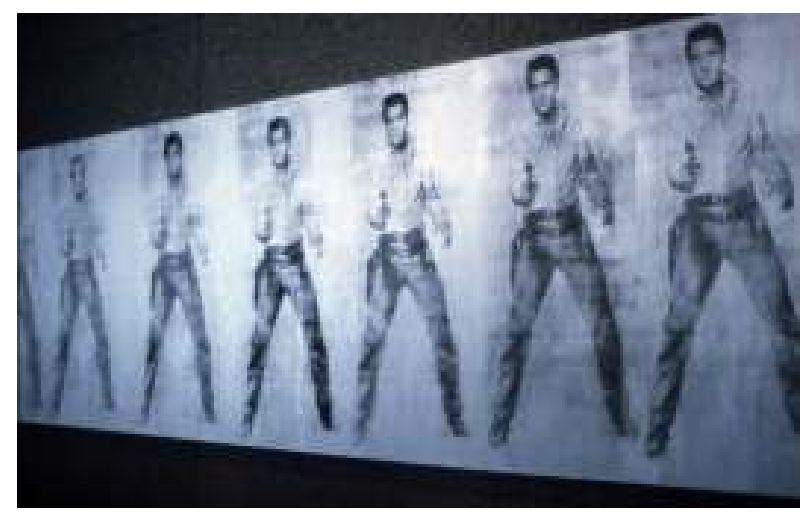

Figure 24:

Elvis 11 Times, 1963

Andy Warhol

Silkscreen ink and silver paint on linen, 82 x 438 in Andy Warhol Museum, Pittsburgh 


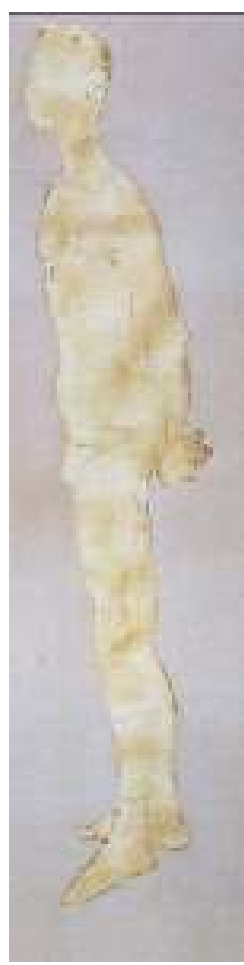

Figure 25:

Golden Boy, 1957

Andy Warhol

Ink and gold leaf on paper, 97 x 35 5/8 in Collection of Erich Marx, Berlin

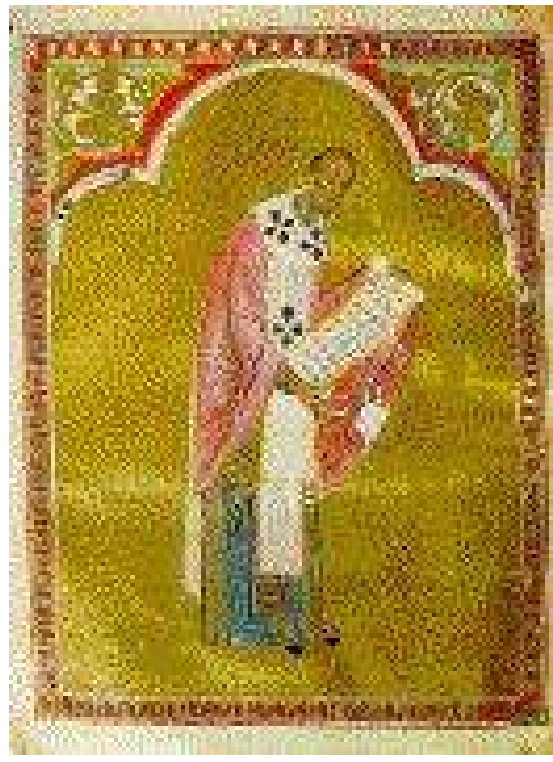

Figure 26:

Icon of St. Andrew 


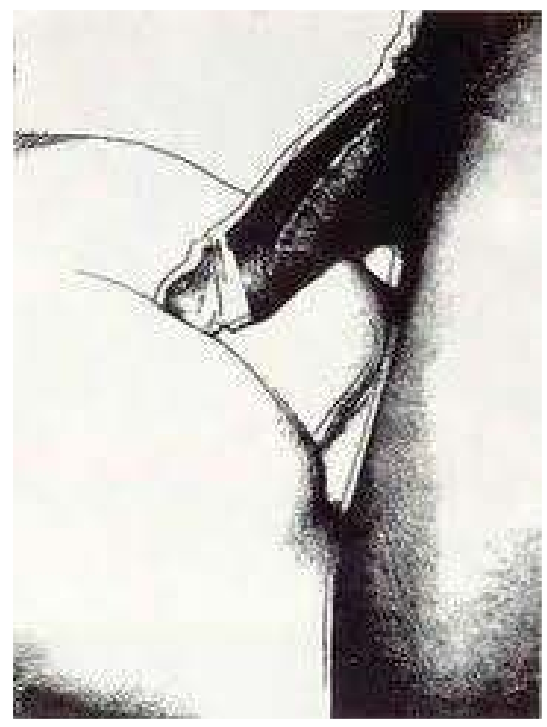

Figure 27:

Sex-Parts, 1978

Andy Warhol

Screenprint on HMP paper

$31 \times 23.25$ in

Andy Warhol Enterprises, Inc., New York

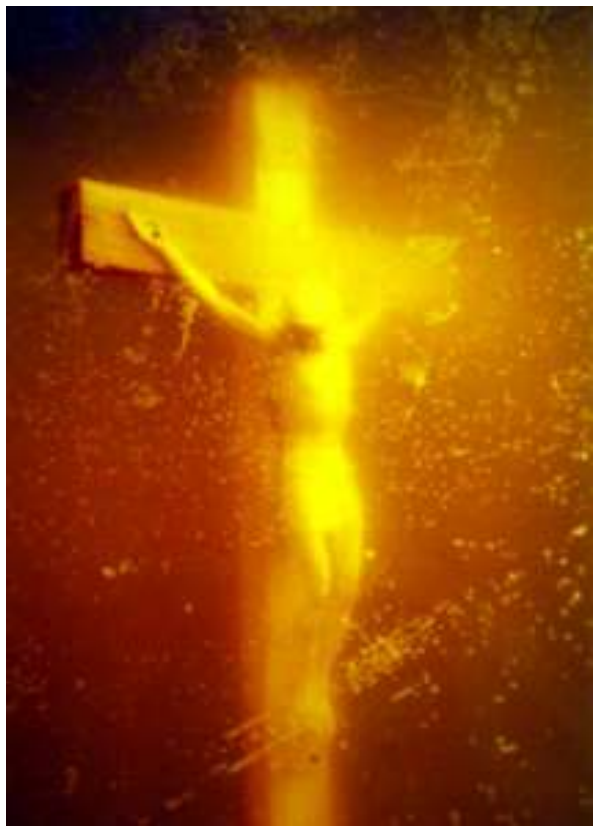

Figure 28:

Piss Christ, 1987

Andres Serrano

Photograph 


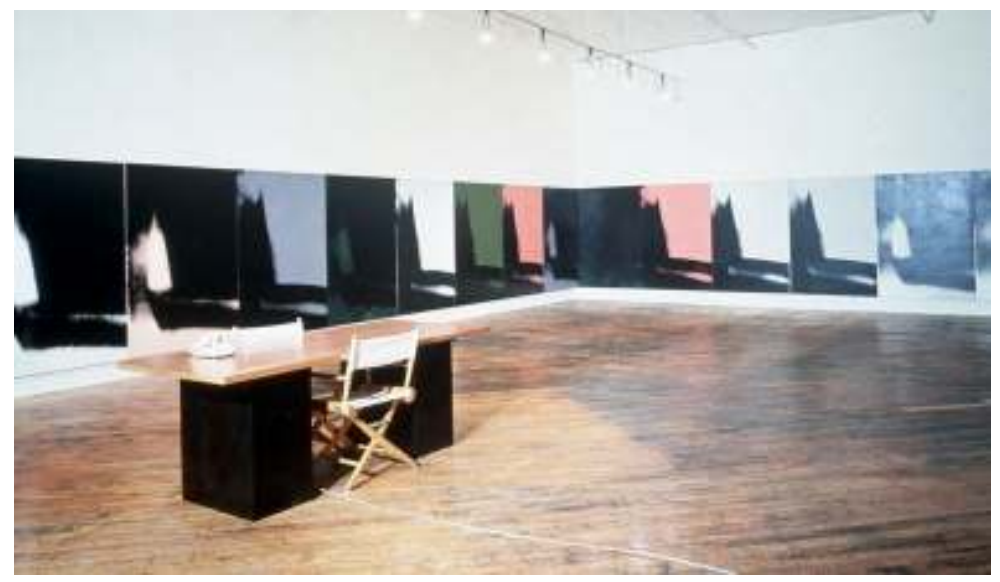

Figure 29:

Shadows (installation), 1978

Andy Warhol

Acrylic and silkscreen ink on canvas, 102 canvases, $76 \times 52$ in Collection Dia Art Foundation, New York

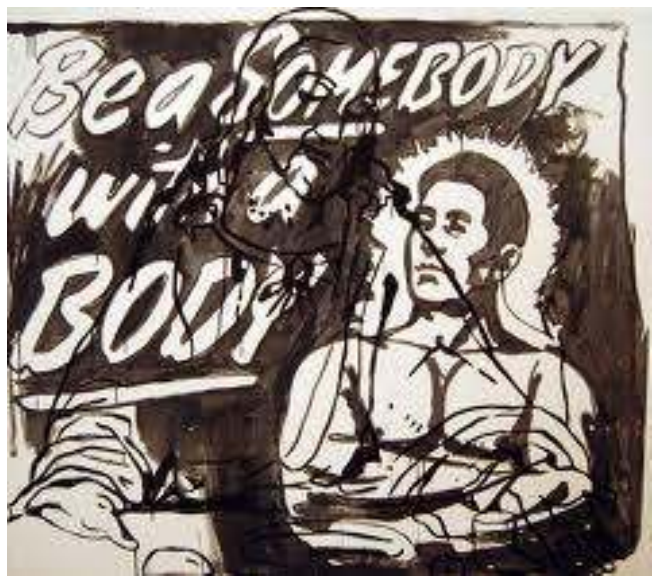

Figure 30:

The Last Supper (Be Somebody with a Body) (detail), 1985/86 Andy Warhol

Acrylic on linen, $127 \times 142.2 \mathrm{~cm}$

The Andy Warhol Museum, Pittsburgh 


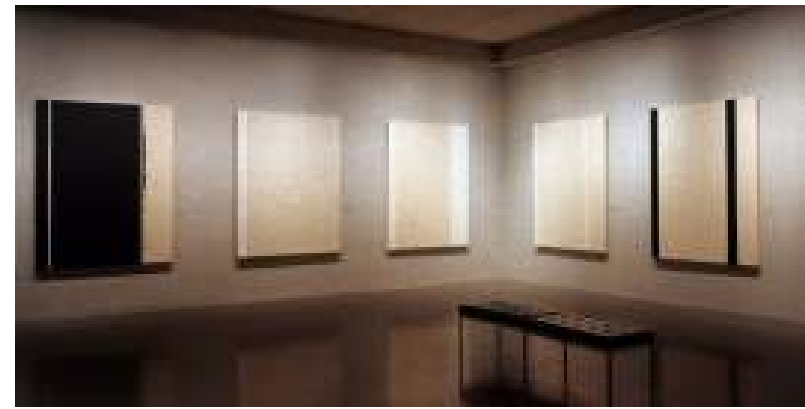

Figure 31:

The Stations of the Cross: Lema Sabachthani (installation), 1966

Barnett Newman

Magna on canvas, fifteen panels, each $78 \times 60.5$ in National Gallery of Art, Washington DC

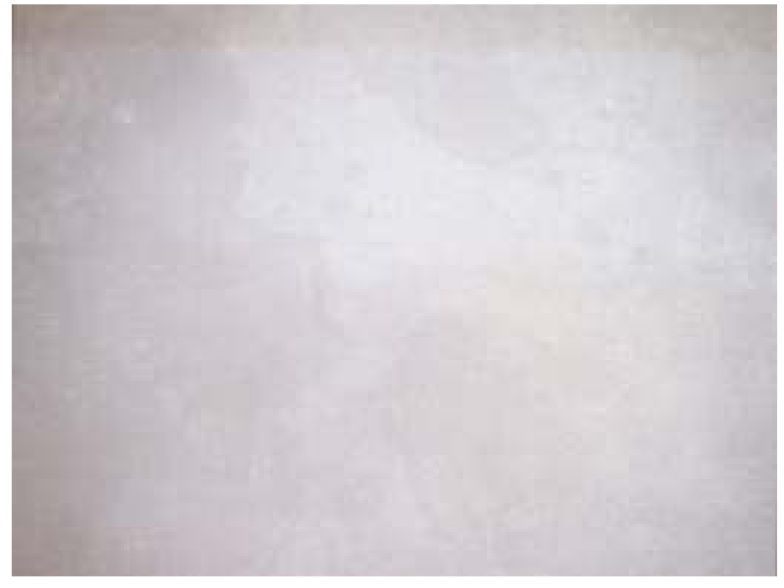

Figure 32:

The Stations of the Cross: Lema Sabachthani, Fourteenth Station, 1966

Barnett Newman

Magna on canvas, fifteen panels, each $78 \times 60.5$ in

National Gallery of Art, Washington DC 


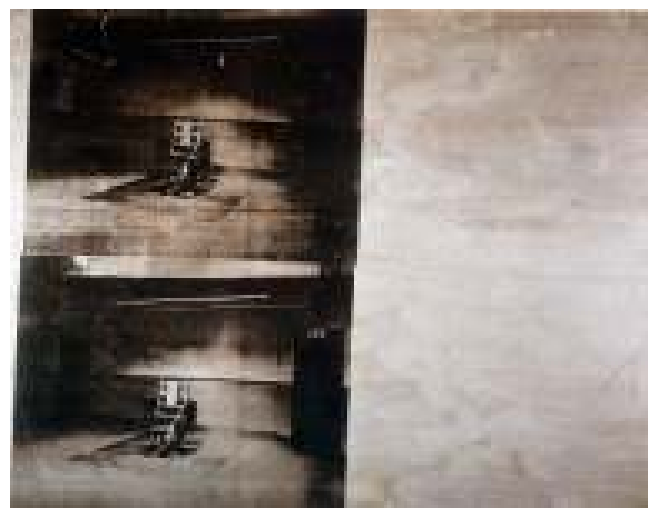

Figure 33:

Double Silver Disaster, 1963

Andy Warhol

Acrylic and liquitex silkscreen on canvas, 106.5 x $132 \mathrm{~cm}$

J.W. Fröhlich Collection, Stuttgart

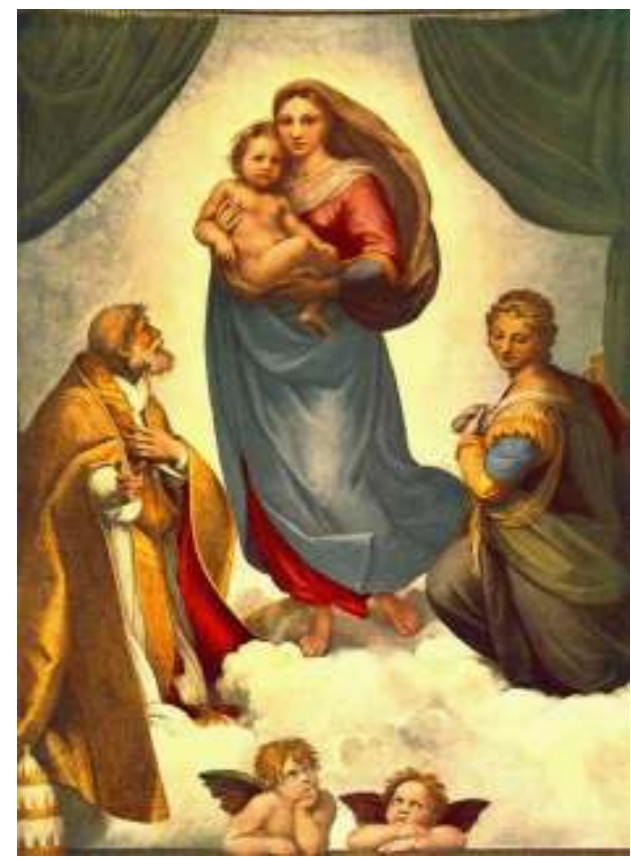

Figure 34:

Sistine Madonna, 1513/14

Raphael

Oil on Canvas, $8 \mathrm{ft} 81 / 2 \times 6 \mathrm{ft} 5$ in

The Old Masters Picture Gallery, Dresden, Germany 


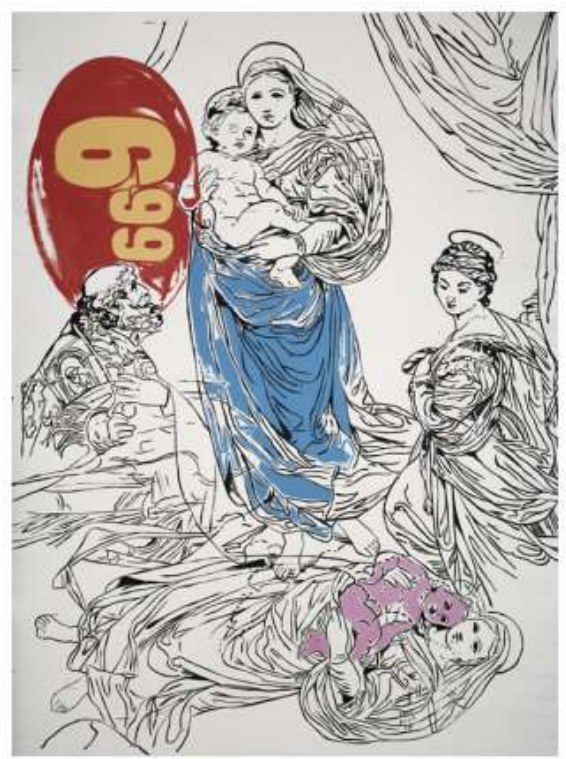

Figure 35:

Raphael I - 6.99, 1985

Andy Warhol

Acrylic on canvas, $13 \mathrm{ft} 1 / 4$ in $\times 9 \mathrm{ft} 8$ in

The Estate of Andy Warhol

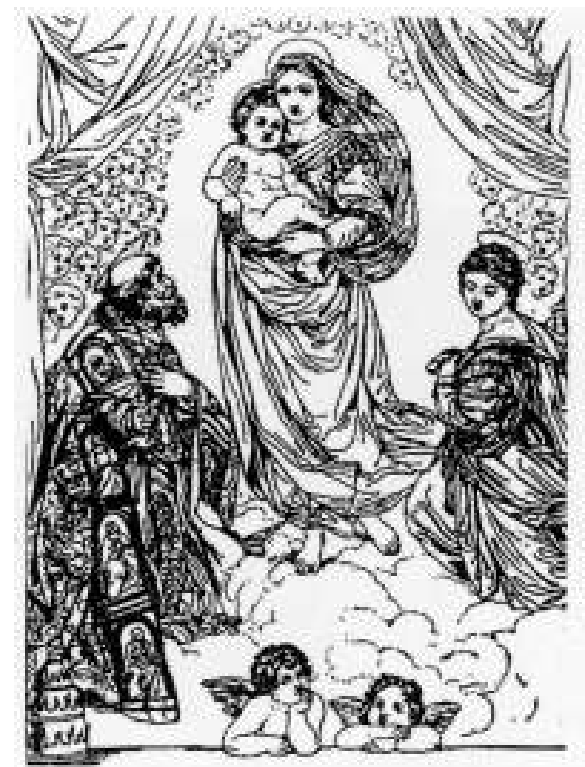

Figure 36:

Encyclopedia Illustration of

Raphael's Sistine Madonna, $19^{\text {th }}$ Century: 


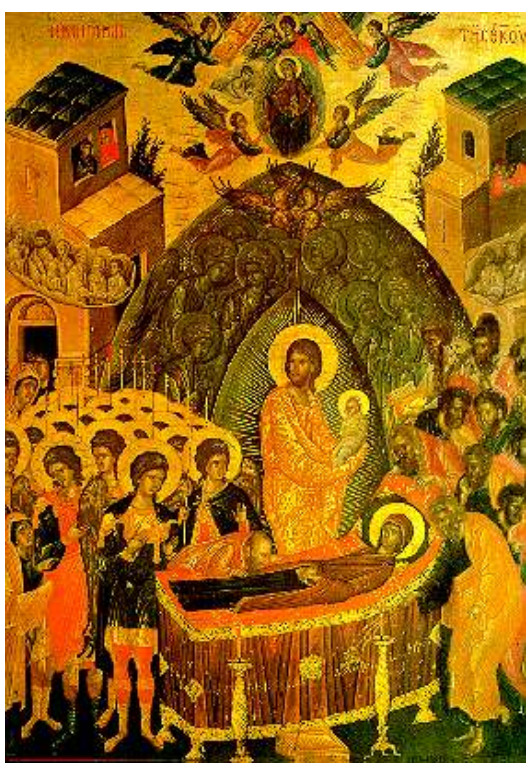

Figure 37:

Icon of The Dormition of the Virgin, $15^{\text {th }}$ Century Andrea Ritzos

Galleria Sabaudo, Turin

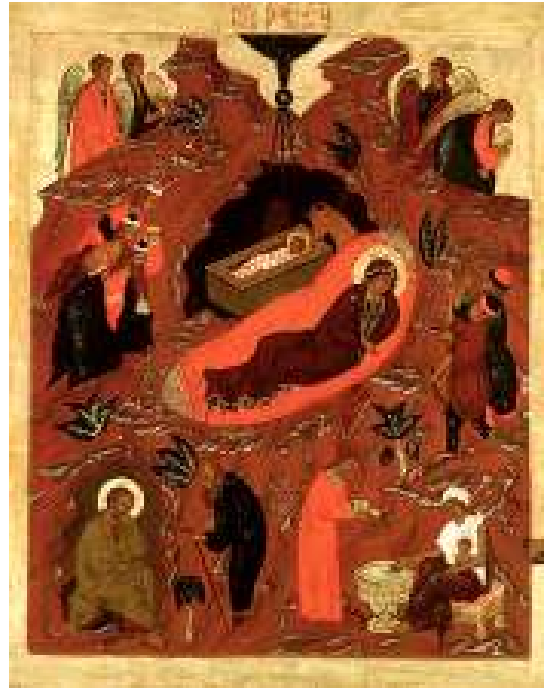

Figure 38:

Icon of The Nativity of Christ 


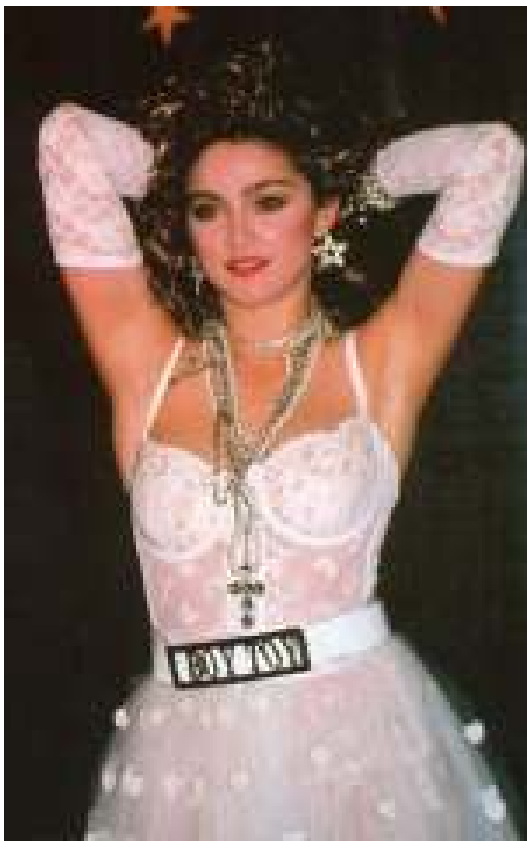

Figure 39:

Photograph of Madonna, 1984

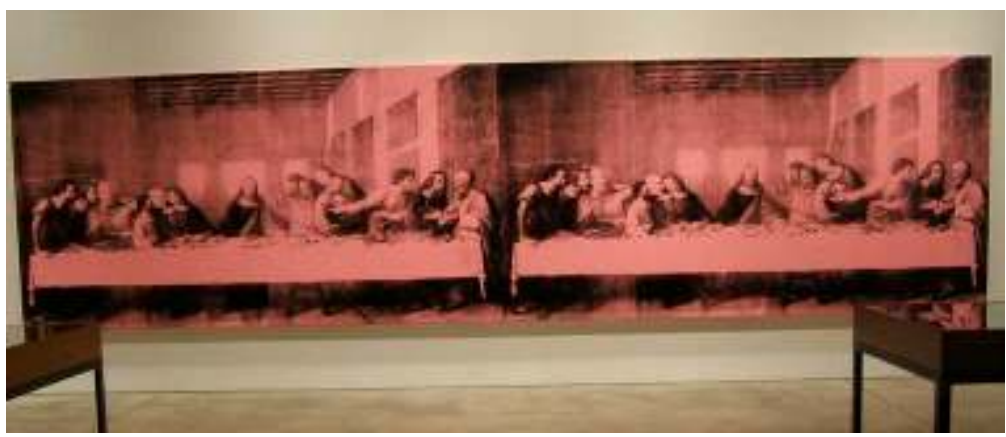

Figure 40:

The Last Supper (Pink) (installation), 1986

Andy Warhol

Synthetic polymer paint and silkscreen on canvas, 78 x 306 in

The Andy Warhol Museum, Pittsburgh

Photograph by Erin Beveridge 


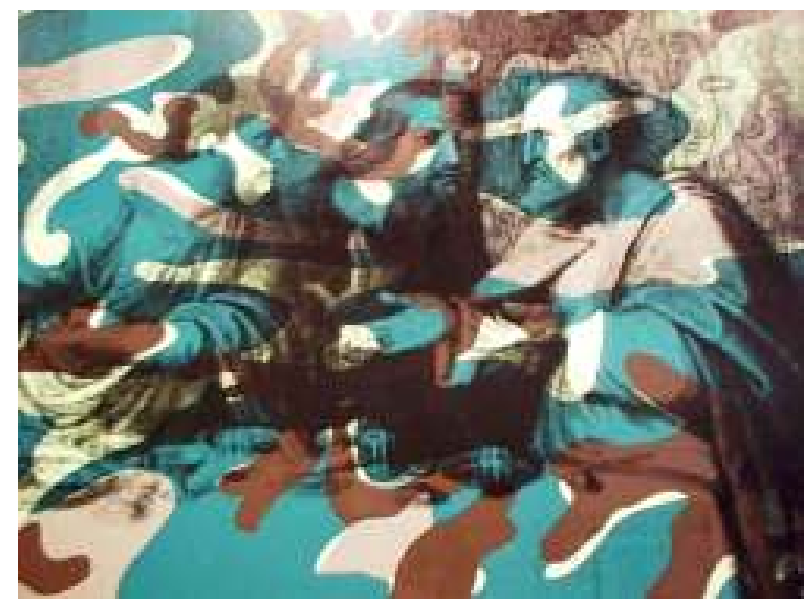

Figure 41:

The Camouflage Last Supper (detail), 1986

Andy Warhol

Synthetic polymer paint and silkscreen on canvas, 78 x 306 in The Menil Collection, Houston

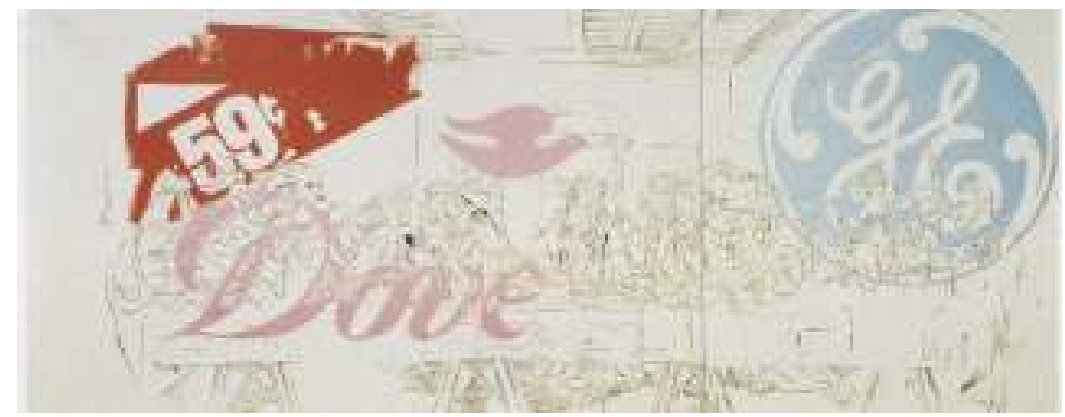

Figure 42:

The Last Supper (Dove), 1986

Andy Warhol

Synthetic polymer paint and silkscreen on canvas, $119 \times 263$ in

The Museum of Modern Art, New York 


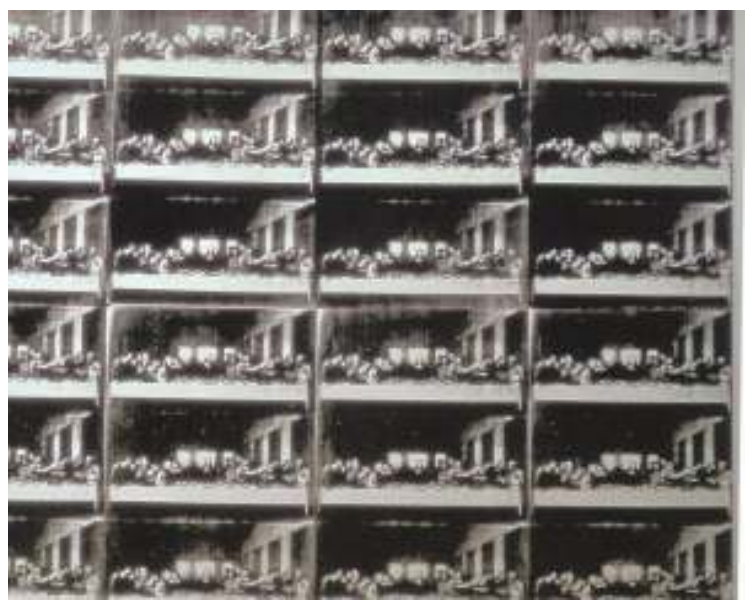

Figure 43:

Sixty Last Suppers (detail), 1986

Andy Warhol

Synthetic Poymer paint and silkscreen on canvas, 116 x 393 in The Andy Warhol Foundation for the Visual Arts, New York

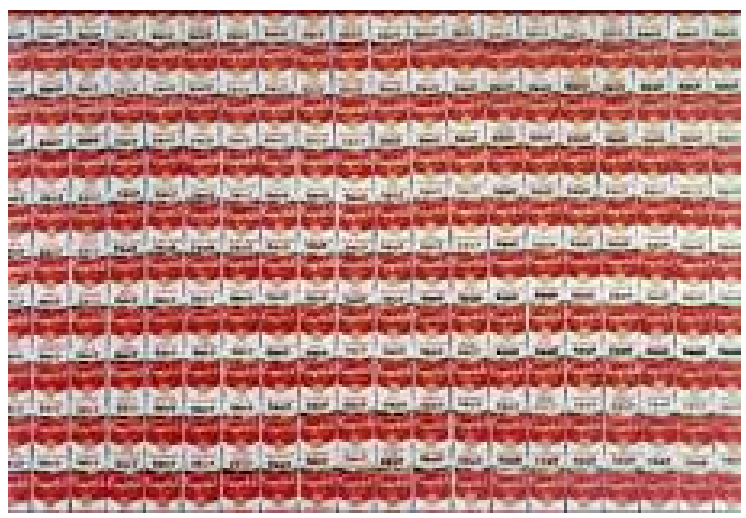

Figure 44:

200 Campbell's Soup Cans, 1962

Andy Warhol

Acrylic on canvas, $72 \times 100$ in

Collection of John and Kimiko Powers 


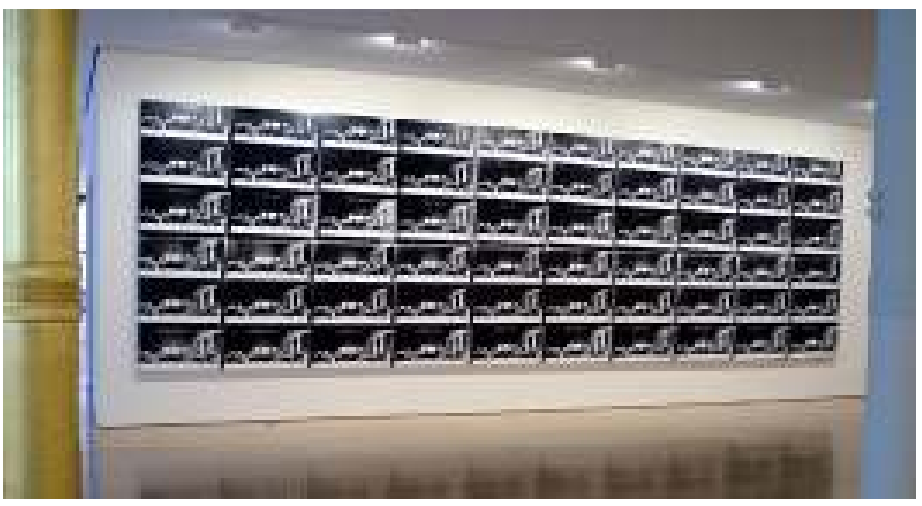

Figure 45:

Sixty Last Suppers (installation), 1986

Andy Warhol

Synthetic Poymer paint and silkscreen on canvas, 116 x 393 in The Andy Warhol Foundation for the Visual Arts, New York 


\section{BIBLIOGRAPHY}

Alpers, Svetlana. The Art of Describing: Dutch Art in the Seventeenth Century. Chicago: The University of Chicago Press, 1983.

Angold, Michael. Byzantium: The Bridge from Antiquity to the Middle Ages. New York: St. Martin's Press, 2001.

Baigell, Matthew. Artist and Identity in Twentieth-Century America. Cambridge: Cambridge University Press, 2001.

Barford, Paul M. The Early Slavs: Culture and Society in Early Medieval Eastern Europe. Ithaca, New York: Cornell University Press, 2001.

Bassler, Josette M. “Cross.” In Harper Collins Bible Dictionary. Ed. Paul J. Achtemeir, 211212. New York: HarperCollins Press, 1996.

Benfey, Christopher. “Objects of Beauty.” http://www.slate.com. Slate (June 26, 1997): 1-3. Accessed February 20, 2008.

Bennett-Carpenter, Benjamin. "The Divine Simulacrum Of Andy Warhol: Baudrillard's Light On The Pope of Pop's 'Religious Art.'" http://www.jcrt.org/archives/01.3/carpenter.html. (August 24, 2000): 1-16. Accessed February 22, 2008.

Bockris, Victor. Warhol: The Biography. London: Da Capo Press, 2003.

Bourdon, David. Warhol, New York: Abradale Press, Harry N. Abrams, Inc., 1989.

Carey, Patrick W. et al. "Chrysostom, John, Saint, Patriarch of Constantinople." http://vnweb.hwwilsonweb.com. Accessed March 18, 2008.

Colacello, Bob. Holy Terror: Andy Warhol Close Up. New York: Cooper Square Press, 1990.

Conlin, Joseph R. The American Past: A Survey of American History. Bellmont: Thomson Wadsworth, 2009.

Connor, Steven. Postmodern Culture: An Introduction to Theories of the Contemporary. Oxford: Blackwell Publishers, 1989.

Constable, Rosalind. "New York's Avant Garde and How It Got There." New York Herald Tribune (May 17, 1964): 10.

Cooke, Lynne. "Andy Warhol: Shadows.” http://www.diacenter.org/exhibs/warhol/shadows/essay/html. Accessed June 10,2008.

Cormack, Robin. Icons. Cambridge: Harvard University Press, 2007. 
Cory, Catherine A. and Hollerich, Michael J., eds. The Christian Theological Tradition. New Jersey: Pearson Prentice Hall, 2009.

Cross, Lawrence. Eastern Christianity: The Byzantine Tradition. Philadelphia: E.J. Dwyer, 1991.

Cutrone, Ronnie. "Still Life and Abstraction." In Andy Warhol "Giant” Size, Edited by Phaidon, 522. London: Phaidon Press Limited, 2006.

Dalton, David. “America the Beautiful.” In Andy Warhol "Giant” Size, Edited by Phaidon, 126. London: Phaidon Press Limited, 2006.

. "Matinee Idols." In Andy Warhol "Giant” Size, Edited by Phaidon, 174. London: Phaidon Press Limited, 2006.

Danto, Arthur C. "From Philosophy to Art Criticism." American Art 16 (Spring, 2002): 1417.

Delpech-Ramey, Joshua. “The Idol as Icon: Andy Warhol's Material Faith.” Angelaki, Journal of the Theoretical Humanities 12 (2007): 96.

Dillenberger, Jane Daggett. The Religious Art of Andy Warhol, New York: The Continuum Publishing Company, 1998.

Dvornik, Francis. "The Significance of the Missions of Cyril and Methodius." Slavic Review 23 (June, 1964): 195-211.

Florensky, Pavel. Iconostasis. US: St. Vladimir's Seminary Press, 1996.

Fortescue, Adrian. "Veneration of Images." Catholic Encylcopedia. http://www.newadvent.org/cathen/07664a.htm. Accessed May 11, 2009.

Foster, Hal. "Death in America." October (Winter, 1996): 36-59.

Ganis, William V. "Andy Warhol's Iconophilia." In Visible Culture / An Electronic Journal for Visual Studies (2000): 1-14. http://www.rochester.edu. Accessed June 24, 2006.

Gilles, Paul. American Catholic Arts and Fictions: Culture, Ideology, Aesthetics. Cambridge: Cambridge University Press, 1992.

Gonzales, Justo L. The Story of Christianity, Volume 1: The Early Church to the Dawn of the Reformation. New York: HarperCollins Publishers, 1984.

Haberstich, David. "Photography and the Plastic Arts." Leonardo 6 (Spring, 1973): 113-119.

Hackett, Pat, ed. The Andy Warhol Diaries. New York: Warner Books, 1989.

Hall, James. Hall's Dictionary of Subjects and Symbols in Art. London: John Murray, 1974. 
Hartt, Frederick, and Wilkins, David G. History of Italian Renaissance Art. Upper Saddle River, New Jersey: Prentice Hall, 2007.

Harrison, Charles; Wood, Paul, eds. Art in Theory. Oxford: Blackwell Publishing, 2003.

Heartney, Eleanor. Critical Condition: American Culture at the Crossroads, Cambridge: Cambridge University Press, 1997.

. Postmodern Heretics / The Catholic Imagination in Contemporary Art. New York: Midmarch Arts Press, 2004. . Postmodernism. Cambridge: Cambridge University Press, 2001.

Herbenick, Raymond M. Andy Warhol's Religious and Ethnic Roots: The Carpatho-Rusyn Influence on His Art, New York, Ontario, United Kingdom: The Edwin Mellen Press, 1997.

Hickey, Dave. "Introduction: Andy and the Dreams that Stuff is Made of." In Andy Warhol "Giant" Size. Edited by Phaidon, 7-12. London: Phaidon Press Limited, 2006.

Ho, Melissa, ed. Reconsidering Barnett Newman. New Haven, London: Yale University Press, 2005.

Horvat, Ed. Interview with author, December 9, 2009.

Howe, Nicholas, ed., Ceremonial Culture in Pre-Modern Europe, Notre Dame: University of Notre Dame Press, 2007).

Jameson, Fredric. Postmodernism, Or, The Cultural Logic of Late Capitalism. Durham: Duke University Press, 1991.

. "The Deconstruction of Expression." In Art in Theory, 1046-1051. Edited by Charles Harrison and Paul Wood. Oxford: Blackwell Publishing, 2003.

John of Damascus. "Medieval Sourcebook: John of Damascus: In Defense of Icons, c. 730." http://www.fordham.edu/halsall/source/johndam-icons.html. Accessed May 11, 2009.

Jones, Caroline A. Machine in the Studio: Constructing the Postwar American Artist. Chicago: The University of Chicago Press, 1996.

Jones, Pamela M. "The Reception of Christian Devotional Art: The Renaissance in the Present." Art Journal 57 (Spring 1998): 2-4.

Kalina, Richard. "Andy Warhol at the Dia Center.” Art in America 88 (February 1, 2000): 129.

Kattenberg, Peter. Andy Warhol, Priest: The Last Supper Comes in Small, Medium and Large. Boston: Brill, 2001.

Kellein, Thomas, et al. Andy Warhol Abstracts. Munich, New York: Prestel-Verlag, 1993. 
Kenna, Margaret. "Icons in Theory and Practice: An Orthodox Christian Example." History of Religions 24 (May, 1985): 345-368.

Ketner, Joseph D., ed., Andy Warhol: The Last Decade. New York: Prestel Publishing, 2009.

Kiefer, James. "Cyril and Methodius." http://satucket.com/lectionary/Cyril\&Methodius.htm. Accessed May 11, 2009.

Kimball, Virginia M. "A Reflection on the Feast of the Assumption." http://campus.udayton.edu/mary/images/icons/maria.jpg. Accessed March 19, 2009.

Kuspit, Donald. The End of Art. Cambridge: Cambridge University Press, 2004.

Laham, Gregory. "Orientale Lumen." Ecumenical Trends 31 (October, 2002): 129-134.

Liedtke, Walter. Dutch Paintings in the Metropolitan Museum of Art. New York: The Metropolitan Museum of Art, 2007.

Limouris, Gennadios, ed., Icons: Windows on Eternity. Geneva: WCC Publications, 1990.

Lippard, Lucy. Pop Art. London: Thames \& Hudson Ltd, 1966.

Lobel, Michael. "Warhol's Closet." Art Journal 55 (Winter, 1996): 42-50.

Magocsi, Paul R. and Pop, Ivan, eds. Encyclopedia of Rusyn History and Culture. Toronto: University of Toronto Press, 2002.

Magocsi, Paul R. Our People: Carpatho-Rusyns and Their Descendents in North America. Ontario: Multicultural History Society of Ontario, 1984.

. "Carpatho-Rusyn Americans." http://www.everyculture.com/multi/BuDr/Carpatho-Rusyn-Americans.html. Accessed November 15, 2009.

Martin, Linette. Sacred Doorways: A Beginner's Guide to Icons. Brewster, MA: Paraclete Press, 2002.

Matthews, Thomas F. "Tillich on Religious Content in Modern Art." Art Journal 27 (Autumn, 1967): 16-19.

McBrien, Richard P., ed. The Harpercollins Encyclopedia of Catholicism. San Francisco: HarperCollins Publishers, 1995.

McDannell, Colleen. Material Christianity: Religion and Popular Culture in America. New Haven: Yale University Press, 1998.

Mead, Frank S. et al. Handbook of Denominations in the United States. Nashville: Abingdon Press, 2005. 
O'Connor, John, and Liu, Benjamin. Unseen Warhol, New York: Rizzoli International Publications, Inc., 1996.

Ouspensky, Leonid and Lossky, Vladimir. The Meaning of Icons. Crestwood, NY: St. Vladimir's Seminary Press, 1982.

Ratcliff, Carter. Andy Warhol. New York: Abbeville Press, 1983.

Roth, Catherine P. In Theodore the Studite, On the Holy Icons, Crestwood, New York: St. Vladimir's Seminary Press, 2001.

Ruether, Rosemary Radford. Mary - The Feminine Face of the Church. Philadelphia: The Westminster Press, 1977.

Scherman, Tony, and Dalton, David. Pop: The Genius of Andy Warhol. New York: HarperCollins Press, 2009.

Schmuckli, Claudia. "Andy Warhol, The Last Supper." http://www.guggenheim.org/exhibitions/warhol/warhol_bottom_index.html. Accessed March 18, 2008.

Schwartz, Lillian F. "The Staging of Leonardo's "Last Supper": A Computer-Based Exploration of Its Perspective." Leonardo 1 (1988): 898-96.

Shipman, Andrew. "Ruthenians." Catholic Encyclopedia. Accessed May 11, 2009. http://www.newadvent.org/cathen/13278a.htm.

Shlikhta, Natalia. "Greek Catholic' - 'Orthodox' - 'Soviet' A Symbiosis or a Conflict of Identities?" Religion, State and Society 32 (September, 2004): 261-273.

Smee, Sebastian. "Debating the political artistry of a Pop icon." The Boston Globe (October 7, 2008). Accessed November 9, 2009. http://www.boston.com.

Smith, Patrick S. Andy Warhol's Art and Films. Ann Arbor: UMI Research Press, 1981.

Steinberg, Leo. Leonardo's Incessant Last Supper. New York: Zone Books, 2001.

Stephanson, Anders. "Regarding Postmodernism - A Conversation with Fredric Jameson." In Universal Abandon?: The Politics of Postmodernism. Edited by Andrew Ross. Minneapolis: University of Minnesota Press, 1998.

Stoichita, Victor I. A Short History of the Shadow. London: Reaktion Books Ltd., 1997.

Stokstad, Marilyn. Art History: Medieval Art. Upper Saddle River, New Jersey: Pearson Prentice Hall, 2009.

Stuckey, Charles et al. Andy Warhol: Heaven and Hell Are Just One Breath Away! New York: Rizzoli, 1992. 
Sullivan, Scott A. "A Banquet-Piece with Vanitas Implications." The Bulletin of the Cleveland Museum of Art 61 (October, 1974): 271-82.

Swenson, G.R. "What is Pop Art?: Answers from Painters, Part I." ARTnews (November, 1963).

Temkin, Ann, ed. Barnett Newman. Philadelphia: Philadelphia Museum of Art, 2002.

Theodore the Studite. On the Holy Icons. Translated by Catharine P. Roth. Crestwoood, New York: St. Vladimir's Seminary Press, 2001.

Unknown Author. "Painter Hangs His Own Paintings." New York Magazine 5 (February, 1979): n.p.

Unknown author. "Divine Liturgy of St. John Chrysostom." Accessed April 27, 2008. http://esoptron.umd.edu/ugc/liturgy1.html.

Unknown author. "Iconography." Accessed April 28, 2008. http://www.stgeorgedowney.org/iconography.html.

Unknown author. "Grace of Baptism." Accesssed April 29, 2008. http://www.vatican.va/archive/eng0015/_p3n.htm.

Vasari, Giorgio. "Giorgio Vasari: The Lives of the Artists, 1568." Accessed April 3, 2007. www.fordham.edu.

Vinje, Sr. Marcia. "Icons." Accessed February 22, 2008.

http://campus.udayton.edu/mary/images/icons/maria.jpg.

Volk, Gregory. "The Late, Great Andy Warhol." In Andy Warhol: The Last Decade. Edited by Joseph D. Ketner. New York: Prestel Publishing, 2009.

Warhol, Andy, and Hackett, Pat. Popism: The Warhol Sixties. New York: Harcourt, Inc., 1980.

Warhola, James. E mail interview with author, February 22, 2008.

Zananiri, G. Histoire de l'eglise Byzantine. Paris: Nouvelles editions latines, 1954.

Zelensky, Elizabeth; Gilbert, Lela. Windows to Heaven / Introducing Icons to Protestants and Catholics. Grand Rapids, Michigan: Brazos Press, 2005. 
CURRICULUM VITAE

\author{
Linda Rosefsky \\ 640 White Avenue \\ Morgantown, West Virginia 26501 \\ (304) 292-0980 \\ Rosefskys@aol.com
}

\title{
EDUCATION
}

West Virginia University, Morgantown, West Virginia

MA Degree in Art History, 2011

BA Degree in Art History, 2008

Area of Study: Contemporary Art

Advisor: Kristina Olson

Thesis: The Sacred in the Profane: Understanding Andy Warhol's Relationship with the Visual Image

Committee Members: Professor Kristina Olson and Dr. Janet Snyder, College of Creative Arts at West Virginia University; Dr. Jane B. Donovan, Eberly College of Arts and Sciences at West Virginia University; Dr. Cynthia Persinger, Department of Art and Design, California University of Pennsylvania

El Camino College, Torrance, California

AA Degree, 1982-1985

Area of Study: Fine Art

\section{TEACHING EXPERIENCE}

Instructor of Record, Contemporary Art, West Virginia University, Spring 2011

Graduate Teaching Assistant and Guest Lecturer, West Virginia University, 2009-2010

Created art curricula for community centers and taught children's classes: Dare to Draw, Every Picture Tells a Story, Discovering Great Artists, and Beyond the Brush, Stuart and Jupiter, Florida, 2002-2005

\section{AWARDS/HONORS}

Dean's List, 2007-2009

Awarded Graduate Teaching Assistantships, West Virginia University, 2009-2011

Earned BA Degree with Honors, Magna Cum Laude, 2008

\section{CONFERENCE/SYMPOSIUM PRESENTATIONS}

Southeastern College Art Conference, 2010

Midwest Art History Society Annual Conference, 2010

The Many Faces of Piracy Conference, California University of Pennsylvania, 2008 Capstone Project, West Virginia University, 2008

Art History Society Symposium, West Virginia University, 2006 


\section{PROFESSIONAL MEMBERSHIPS}

Southeastern College Art Conference

College Art Association

Midwest Art History Society

American Academy of Religion

\section{SERVICE}

Volunteer History: Morgantown Theatre Company, Morgantown, West Virginia; Marietta Museum of Art, Marietta, Georgia; League of Women Voters, Torrance Historical Society, American Planning Association, Vietnam Veterans of America, Torrance, California

\section{COMPUTER SKILLS}

Microsoft Word, PowerPoint, Excel, Adobe Illustrator, Pagemaker, InDesign

\section{OTHER EXPERIENCE}

Graphic design/illustration: printed promotional materials and visual presentations. Supervised one assistant. City of Torrance Planning Department, Torrance, California, 1989-1999.

Curatorial: assisted curator in planning and hanging monthly art exhibits, designed wall text and visuals, organized receptions. City of Torrance Parks and Recreation Department, Torrance, California, 1987-1989.

\section{John H. $\mathrm{DN}: \mathrm{cn}=J$ John H. Hagen, $\mathrm{o}=$ Wes
Virginia University Libraries,

